

\title{
Toekomstperspectief agrosector Flevoland
}

Theo Vogelzang, Bert Smit, Jakob Jager, Henri Prins, David Verhoog en Krijn Poppe 


\section{Toekomstperspectief agrosector Flevoland}

Theo Vogelzang, Bert Smit, Jakob Jager, Henri Prins, David Verhoog en Krijn Poppe 
Vogelzang, T.A., A.B. Smit, J.H. Jager, H. Prins, A.D. Verhoog en K.J. Poppe, 2016.

Toekomstperspectief agrosector Flevoland. Wageningen, LEI Wageningen UR (University \& Research centre), LEI Report 2016-008. 80 blz.; 28 fig.; 21 tab.; 24 ref.

De sociaaleconomische toekomst van de provincie Flevoland hangt deels samen met de perspectieven van het agrocluster, het totaal van land- en tuinbouwbedrijven, visserij, voedings- en genotmiddelenindustrie en de aan deze sectoren toeleverende bedrijven. In dit rapport is het belang van dit cluster voor Flevoland in kaart gebracht, met een accent op de primaire sectoren, de land- en tuinbouwbedrijven. De huidige situatie van deze bedrijven is in beeld gebracht evenals de ontwikkelingen in de afgelopen tien jaar en de perspectieven voor de komende tien jaar. Daarbij is ook aandacht besteed aan de leefbaarheid van het platteland en de invloed van de agrosector daarop.

The socio-economic future of the Dutch province of Flevoland is partly linked to the perspectives of the agrocluster, the combination of agri- and horticultural firms, fishery, food and luxury industry and the firms that supply these sectors. In this report, the importance of this cluster for Flevoland is described, with a focus on the primary sectors, the agri- and horticultural firms. The current situation of these firms is presented, including the developments in the recent decade and the perspectives for the next decade. Attention is also paid to the quality of life in the countryside and the influence of the agro sector on this aspect.

Trefwoorden: Flevoland, agrocluster, structuur, akkerbouw, melkveehouderij, perspectieven, verbreding, platteland

Dit rapport is gratis te downloaden op http://dx.doi.org/10.18174/375485 of op www.wageningenUR. nl/lei (onder LEI publicaties).

(C) 2016 LEI Wageningen UR

Postbus 29703, 2502 LS Den Haag, T 07033583 30, E informatie.lei@wur.nl, www.wageningenUR.nl/lei. LEI is onderdeel van Wageningen UR (University \& Research centre).

\section{(cc) BY-NC}

LEI hanteert voor haar rapporten een Creative Commons Naamsvermelding 3.0 Nederland licentie.

(c) LEI, onderdeel van Stichting Dienst Landbouwkundig Onderzoek, 2016

De gebruiker mag het werk kopiëren, verspreiden en doorgeven en afgeleide werken maken. Materiaal van derden waarvan in het werk gebruik is gemaakt en waarop intellectuele eigendomsrechten berusten, mogen niet zonder voorafgaande toestemming van derden gebruikt worden. De gebruiker dient bij het werk de door de maker of de licentiegever aangegeven naam te vermelden, maar niet zodanig dat de indruk gewekt wordt dat zij daarmee instemmen met het werk van de gebruiker of het gebruik van het werk. De gebruiker mag het werk niet voor commerciële doeleinden gebruiken.

Het LEI aanvaardt geen aansprakelijkheid voor eventuele schade voortvloeiend uit het gebruik van de resultaten van dit onderzoek of de toepassing van de adviezen.

Het LEI is ISO 9001:2008 gecertificeerd.

LEI 2016-008 | Projectcode 2282700170

Foto omslag: Shutterstock 


\section{Inhoud}

Woord vooraf $\quad 5$

$\begin{array}{ll}\text { Samenvatting } & 6\end{array}$

S.1 Belangrijkste uitkomsten $\quad 6$

S.2 Overige uitkomsten $\quad 6$

$\begin{array}{ll}\text { S.3 Methode } & 7\end{array}$

$\begin{array}{ll}\text { Summary } & 8\end{array}$

$\begin{array}{lll}\text { S.1 Principal outcomes } & 8\end{array}$

$\begin{array}{lll}\text { S.2 Other outcomes } & 8\end{array}$

$\begin{array}{ll}\text { S.3 Method } & 9\end{array}$

1

Inleiding

$\begin{array}{llr}1.1 & \text { Aanleiding } & 10\end{array}$

$\begin{array}{lll}1.2 & \text { Probleemstelling } & 10\end{array}$

$\begin{array}{llr}1.3 & \text { Doelstelling } & 10\end{array}$

$\begin{array}{llr}1.4 & \text { Aanpak } & 10\end{array}$

$\begin{array}{ll}\text { Structuurverkenning } & 12\end{array}$

2.1 Inleiding 12

2.2 Totaalbeeld arealen 12

$\begin{array}{lll}2.3 & \text { Akkerbouw en vollegrondsgroenteteelt } & 13\end{array}$

$\begin{array}{lll}2.4 & \text { Tuinbouw } & 15\end{array}$

2.5 Melkvee- en graasdierhouderij 16

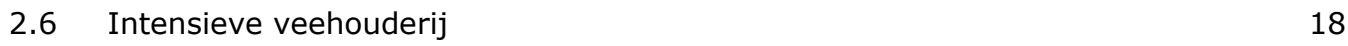

$\begin{array}{ll}2.6 .1 \text { Varkenshouderij } & 18\end{array}$

$\begin{array}{ll}2.6 .2 \text { Pluimveehouderij } & 19\end{array}$

$\begin{array}{lll}2.7 & \text { Aantal bedrijven en schaalgrootte } & 20\end{array}$

2.8 Opvolgingssituatie en positie van gezinsbedrijven in Flevoland 26

2.9 Verbreding 28

2.10 Grondposities en verkavelingssituatie $\quad 31$

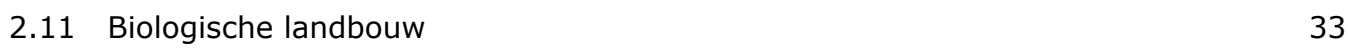

2.12 Opbrengend vermogen van de grond $\quad 34$

2.13 Inkomensontwikkeling en saldi in de land- en tuinbouwsectoren 36

2.14 Gemeenschappelijk Landbouwbeleid $\quad 39$

$\begin{array}{ll}2.15 \text { Conclusies } & 41\end{array}$

$3 \quad$ Het agrocluster in Flevoland $\quad 43$

$\begin{array}{lll}3.1 & \text { Inleiding } & 43\end{array}$

3.2 Betekenis van het agrocluster in Flevoland 43

$\begin{array}{lll}3.3 & \text { Conclusies } & 46\end{array}$

Trends en ontwikkelingen in de agrosectoren (inclusief conclusies per sector) 48

$\begin{array}{lll}4.1 & \text { Inleiding } & 48 \\ 4.2 & \text { Akkerbouw en vollegrondsgroenten } & 48 \\ 4.3 & \text { Bloembollenteelt } & 53 \\ 4.4 & \text { Glastuinbouw } & 54 \\ 4.5 & \text { Melkveehouderij } & 55 \\ 4.6 & \text { Varkenshouderij } & 57\end{array}$ 
$\begin{array}{lll}4.7 & \text { Pluimveehouderij } & 57\end{array}$

$\begin{array}{lll}4.8 & \text { Biologische landbouw } & 58\end{array}$

5.1 Inleiding $\quad 59$

$\begin{array}{ll}5.2 & \text { Leefbaarheid } \\ 5.3 & 59\end{array}$

$\begin{array}{lll}5.3 & \text { Vrijkomende erven } & 60\end{array}$

$\begin{array}{lll}5.4 & \text { Ontsluiting landelijk gebied } & 61\end{array}$

$\begin{array}{lll}5.5 & \text { Bodemdaling } & 61\end{array}$

5.6 Kansen in de keten $\quad 62$

$\begin{array}{lll}5.7 & \text { Pionieren } 2.0 & 62\end{array}$

$\begin{array}{lll}5.8 & \text { Uitbreidingsmogelijkheden veehouderij } & 62\end{array}$

$\begin{array}{lll}5.9 & \text { Overige punten uit de AVP } & 63\end{array}$

$\begin{array}{lll}5.10 & \text { Conclusies } & 64\end{array}$

$6 \quad$ Toekomstperspectief voor de periode tot 2025

6.1 Toekomstverwachtingen per sector $\quad 66$

6.2 Verwachte arealen, veestapel en aantallen bedrijven in 202566

$7 \quad$ Conclusies en aanbevelingen $\quad 69$

$\begin{array}{llr}7.1 & \text { Conclusies } & 69\end{array}$

$\begin{array}{lll}7.2 & \text { Aanbevelingen } & 70\end{array}$

$\begin{array}{ll}\text { Literatuur } & 73\end{array}$

$\begin{array}{lll}\text { Bijlage } 1 & \text { Aanvullende informatie bij Figuur } 2.1 & 75\end{array}$

$\begin{array}{lll}\text { Bijlage } 2 & \text { Aanvullende informatie bij Figuur } 2.8 & 76\end{array}$

$\begin{array}{lll}\text { Bijlage } 3 & \text { Aanvullende informatie bij Figuur 2.23 } & 77\end{array}$

Bijlage 4 Achtergrond bij de input-outputanalyse in hoofdstuk $3 \quad 78$

$\begin{array}{lll}\text { Bijlage } 5 & \text { Cijfers bij Figuur 2.10 } & 79\end{array}$ 


\section{Woord vooraf}

De agrarische sector in Flevoland is op veel plaatsen beeldbepalend, doordat een groot deel van de grond door akkerbouw-, melkvee- en andersoortige agrarische bedrijven wordt gebruikt. Daarnaast is het agrocluster voor een relatief groot deel van de toegevoegde waarde en de werkgelegenheid in de provincie verantwoordelijk. De sociaaleconomische toekomst van de provincie Flevoland hangt daarom voor een belangrijk deel samen met de perspectieven van het agrocluster. De leefbaarheid van het Flevolandse platteland wordt daarbij in sterke mate beïnvloed door de ontwikkelingen op de primaire bedrijven. Er zijn daarbij dwarsverbanden met dossiers als 'water', 'natuur', 'vitaal platteland' en 'omgevingsvisie'.

De provincie Flevoland heeft begin 2015 aangegeven dat er behoefte is aan een Landbouwverkenning voor haar grondgebied. Na de provinciale verkiezingen in 2014 achtte men een dergelijke verkenning van belang voor de beleidsvorming van het nieuwe college van Gedeputeerde Staten. Deze opdracht is aan LEI Wageningen UR verstrekt en in de tweede helft van 2015 in nauwe interactie met een begeleidingsgroep vanuit de Provincie tot stand gekomen. In die groep zaten Hans Koole, Martin Griffioen en Reina Groen, die daarmee verschillende dossiers in het onderzoek vertegenwoordigden. Hun nauwe en prettige betrokkenheid bij het onderzoek is door de onderzoekers op prijs gesteld.

Namens het LEI is het onderzoek uitgevoerd door Theo Vogelzang (projectleider), Bert Smit (onderzoeker ondernemerschap, GLB en duurzame akkerbouw), Jakob Jager (datavoorziening primaire sector), Henri Prins (landbouweconomie), David Verhoog (datavoorziening en analyse agrocluster) en Krijn Poppe (reviewer op hoofdlijnen). De uitkomsten van het onderzoek zijn op 16 december 2015 in grote lijnen gepresenteerd en besproken tijdens een bijeenkomst met ongeveer 25 medewerkers van provincie Flevoland in het 'Atelier Flevo-perspectieven' in Lelystad, 'een plek om gesprekken met elkaar aan te gaan over de toekomst van Flevoland' (www.flevoland.nl/Dossiers/Visie-opFlevoland/Het-Atelier-Flevo-perspectieven). Dit rapport zal een belangrijke bouwsteen vormen om die toekomst vorm te geven.

LEI Wageningen UR bedankt de provincie voor deze opdracht en voor de goede samenwerking.

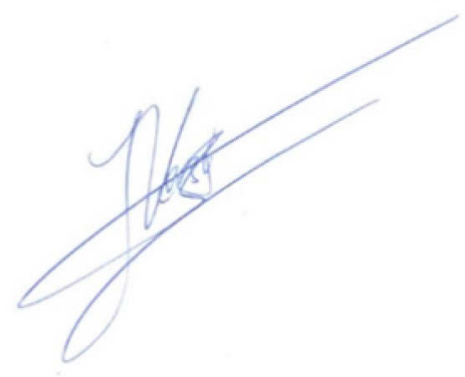

Prof.dr.ir. Jack (J.G.A.J.) van der Vorst

Algemeen Directeur SSG Wageningen UR 


\section{Samenvatting}

\section{S.1 Belangrijkste uitkomsten}

De land- en tuinbouw in Flevoland staat er goed voor. De bedrijfsstructuur en -omvang zijn gunstig in vergelijking met vergelijkbare bedrijfstypes in andere gebieden. De gewasopbrengsten per ha zijn hoog, de melkgift per koe is goed en de melkproductie per ha hoog. De financiële opbrengsten per ha zijn hoog, maar dat geldt ook voor de kosten, zodat het saldo per ha in zowel de akkerbouw als melkveehouderij gemiddeld is. Het hoge kostenniveau en de hoge grondgebruiksintensiteit maken de Flevolandse land- en tuinbouw tot op zekere hoogte ook kwetsbaar. Daarmee rekening houdend zijn er goede toekomstperspectieven voor de komende 10 jaar. Zie paragraaf 7.1 .

De agrarische sector in Flevoland is op veel plaatsen beeldbepalend, doordat een groot deel van de grond door akkerbouw-, melkvee- en andersoortige agrarische bedrijven wordt gebruikt. Daarnaast is het agrocluster voor een groot deel van de toegevoegde waarde en de werkgelegenheid in de provincie verantwoordelijk. De sociaaleconomische toekomst van de provincie Flevoland hangt daarom voor een belangrijk deel samen met de perspectieven van het agrocluster. De leefbaarheid van het Flevolandse platteland wordt daarbij in sterke mate beïnvloed door de ontwikkelingen op de primaire land- en tuinbouwbedrijven. Zie paragraaf 5.2 .

De komende jaren zal een trend van de afgelopen jaren, te weten schaalvergroting en intensivering, zich voortzetten, al zal er wel meer aandacht komen voor duurzaam bodembeheer. Ook zullen meer bedrijven zich met verbredingsactiviteiten bezig gaan houden, met name met be- en verwerking en verkoop van producten op het agrarische bedrijf. Zie paragraaf 5.6.

De biologische sector is in Flevoland groot en zal zich verder ontwikkelen. De intensieve veehouderij zal niet gaan groeien in de provincie; wel is er ruimte voor uitbreiding van de glastuinbouw in de Noordoostpolder. Zie hoofdstuk 2.

Het hoge kennisniveau onder agrarische ondernemers in combinatie met de kennisinstellingen in Flevoland moet benut worden om de provincie nationaal en internationaal nog beter op de kaart te zetten. Flevoland leent zich bij uitstek voor experimenten met precisielandbouw en andere vormen van duurzame en hoogtechnologische landbouw. Ook de productie van inhoudsstoffen in het kader van de biobased economy en de verdere ontwikkeling van biologische landbouw bieden voor een deel van de akkerbouwers perspectief. Zie paragraaf 7.2 .

\section{S.2 Overige uitkomsten}

Qua ruimtegebruik (ruim 70\%) is akkerbouw de belangrijkste agrarische sector in Flevoland, met de melkveehouderij als tweede (20\%). De overige sectoren nemen veel minder ruimte in. De intensieve veehouderij is in Flevoland bescheiden. Zie paragraaf 2.1.

Het aantal akkerbouwbedrijven in Flevoland is de afgelopen tien jaar met $20 \%$ gedaald, wat meer is dan in vergelijkbare akkerbouwgebieden in Nederland. De gemiddelde omzet op de akkerbouwbedrijven is in diezelfde periode met $50 \%$ gestegen. Het aantal melkveebedrijven is sinds 2005 met 9\% gedaald, maar het aantal melkkoeien is met 6.000 dieren gestegen tot ruim 28.000 in totaal. Zie hoofdstuk 2. 
Het aantal bedrijfsopvolgers is in Flevoland groot, met name op de melkveebedrijven. Wat betreft verbreding scoren de agrarische ondernemers in Flevoland vooral hoog op energieproductie, loonwerk en be- en verwerking en verkoop van producten op het bedrijf. Zie hoofdstuk 2.

Het opbrengend vermogen van de grond is hoog, maar staat wel onder druk van het gemiddeld intensieve bouwplan, met veel hakvruchten (aardappelen, bieten, uien, penen). De grondprijs is eveneens bijzonder hoog, maar de verkavelingssituatie in de provincie verslechtert, doordat bedrijven in processen van schaalvergroting of specialisatie grond 'op afstand' bijpachten of -kopen.

Het agrocluster, het totaal van land- en tuinbouwbedrijven, visserij, voedings- en genotmiddelenindustrie en de aan deze sectoren toeleverende bedrijven, is in Flevoland belangrijk. Dit cluster is verantwoordelijk voor ongeveer $15 \%$ van de totale toegevoegde waarde en werkgelegenheid in de provincie. Het akkerbouwcomplex neemt hiervan bijna de helft voor zijn rekening. Verder nemen in Flevoland de visserij- en opengrondstuinbouwclusters een belangrijke plaats in. Zie hoofdstuk 3.

\section{S.3 Methode}

De provincie Flevoland heeft begin 2015 aangegeven dat er behoefte is aan een Landbouwverkenning voor haar grondgebied en het LEI daartoe opdracht gegeven.

In deze studie is aandacht besteed aan de volgende hoofdonderdelen:

1. De huidige staat (of structuur) van de Flevolandse landbouw

2. Een (beperkte) benchmark met vergelijkbare regio's

3. De betekenis van het agrocluster

4. Verwachte trends en ontwikkelingen

5. Het toekomstperspectief voor de komende 10 jaar

6. Advies aan de provincie.

Voor de onderdelen 1 en 2 zijn data verzameld, geanalyseerd en gerapporteerd uit verschillende bronnen, zoals de Landbouwtelling van het CBS, en het Bedrijveninformatienet van het LEI. Daarbij zijn verschillende structuur- en inkomensindicatoren in beeld gebracht voor 2005, 2010 en 2014 voor Flevoland, Nederland als geheel en voor vergelijkbare akkerbouwregio's (de Noordelijke en Zuidwestelijke kleigebieden) en melkveeregio's (Noord-Nederland). Op deze wijze kunnen de ontwikkelingen in de verschillende sectoren in Flevoland ook in perspectief van andere regio's geplaatst worden. Zie hoofdstuk 2.

De betekenis van het agrocluster, onderdeel 3, is in beeld gebracht door een provinciale inputoutputanalyse uit te voeren, gebruik makend van regionale LISA-gegevens (bron: Kamer van Koophandel. Zie hoofdstuk 3.

De verwachte trends en ontwikkelingen, onderdeel 4, zijn in kaart gebracht door ontwikkelingen binnen en buiten Flevoland, bijvoorbeeld qua mestwetgeving of marktontwikkeling, te vertalen naar hun invloed op de trends van de afgelopen jaren in termen van aantallen bedrijven, melkkoeien en bedrijfsomvang. Dat heeft geleid tot een inschatting van het toekomstperspectief voor de komende tien jaar (onderdeel 5), waarbij ook de invloed op de vitaliteit van het platteland is ingeschat. Zie hoofdstukken 4 tot en met 6.

Op basis van al deze informatie en inschattingen zijn diverse brainstormsessies gehouden tussen de begeleidingsgroep van dit onderzoek en het LEI-projectteam, resulterend in een advies aan de provincie Flevoland. Zie paragraaf 7.2. 


\section{Summary}

\section{S.1 Principal outcomes}

Agriculture and horticulture in Flevoland are in good shape. The structure and magnitude of the business are favourable when compared with similar types of business in other areas. The crop yields per hectare are high, the milk yield per cow is good and the milk production per hectare is high. The financial returns per hectare are high, but that also applies to costs, so the balance per hectare in both arable and dairy farming is average. The high level of costs and the high land-use intensity make agriculture and horticulture in Flevoland vulnerable to a certain extent. Taking this into account, the prospects for the next ten years are good. See section 7.1 .

The agrarian sector in Flevoland is a defining feature in many places, as much of the land is used by arable, dairy and other types of farm. Furthermore, the agrocluster is responsible to a large extent for the added value and job opportunities in the province. Consequently, the socio-economic future of the province of Flevoland is related to a significant degree to the prospects of the agrocluster. The viability of rural Flevoland is influenced strongly by the developments in the primary agriculture and horticulture companies. See section 5.2.

In the time ahead the trend of recent years, namely upscaling and intensification, will continue, even though greater attention will be paid to sustainable land management. In addition, more companies will get involved in diversification, especially with regard to treating, processing and selling agrarian products. See section 5.6.

The biological sector is big in Flevoland and will develop even more. Dairy farming, which is already intensive, will not grow in the province, but there is room for expanding greenhouse horticulture in the Noordoostpolder. See chapter 2.

The high level of knowledge among farm operators in combination with the knowledge institutions in Flevoland must be used to put the province even more firmly on the map nationally and internationally. Flevoland is ideally suited to experiments with precision agriculture and other forms of sustainable and high-tech agriculture. The production of constituents in the context of the bio-based economy and the further development of biological agriculture offers prospects to some of the arable farmers. See section 7.2.

\section{S.2 Other outcomes}

In terms of the use of space (more than 70\%) arable farming is the most important agrarian sector in Flevoland, with dairy farming second (20\%). The other sectors use much less space. Intensive cattle farming in Flevoland is modest. See section 2.1.

The number of arable farms in Flevoland has fallen $20 \%$ in the last ten years, which is more than in similar arable farming areas in the Netherlands as a whole. The average turnover of the arable farms rose by $50 \%$ in the same period. The number of dairy farms has declined by $9 \%$ since 2005 , but the total number of dairy cattle has increased by 6,000 to more than 28,000 . See chapter 2 .

The number of takeovers in Flevoland is considerable, especially among dairy farms. As far as diversification is concerned, farm operators in Flevoland score highly, particularly for energy production, for contract work and for treating, processing and selling the farm's products. See chapter 2. 
The productive capacity of the land is high, but is under pressure from the medium-intensive cropping plan with a lot of root crops such as potatoes, beetroot, onions and carrots. The land price is exceptionally high too, but clustering in the province is in decline because companies that are in the process of upscaling or specialisation buy or lease additional local, non-contiguous land.

The agrocluster - the aggregate of agriculture and horticulture companies, fisheries, the food and drink industry and the companies that supply these sectors - is important in Flevoland. This cluster is responsible for roughly $15 \%$ of the total added value and job opportunities in the province. Arable farms contribute around half of this. Moreover, fishery and open-air horticulture clusters have a significant position in Flevoland. See chapter 3.

\section{S.3 Method}

At the beginning of 2015 the province of Flevoland announced that there was a need for an agriculture survey of its territory and commissioned the LEI to carry it out.

This survey focuses on the following main parts:

1. The current state (or structure) of agriculture in Flevoland

2. A (limited) benchmark with comparable regions

3. The significance of the agrocluster

4. Expected trends and developments

5. The prospects for the next ten years

6. Advice for the province.

For parts 1 and 2 data has been collected, analysed and reported from a variety of sources, such as the CBS agricultural census and the Bedrijveninformatienet [LEI Farm Data Network]. Various structure and income indicators for 2005, 2010 and 2014 have thereby been analysed for Flevoland, for the Netherlands as a whole and for comparable arable farming regions (the Northern and Southwestern clay districts) and dairy regions (Northern Netherlands). This enables the developments in the different sectors in Flevoland to be compared with other regions. See chapter 2.

The significance of the agrocluster, part 3, has been surveyed by carrying out a provincial input-output analysis, making use of regional LISA data (source: Chamber of Commerce. See chapter 3.

The expected trends and developments, part 4, have been analysed by translating developments inside and outside Flevoland, for example with respect to fertiliser legislation or market development, into their influence on the trends of recent years in terms of the number of companies and dairy cattle, and farm size. This has led to an estimate of the prospects for the next ten years (part 5), including the effect on the vitality of rural areas. See chapters 4 to 6 .

On the basis of all this information and estimates, various brainstorming sessions have been held between the guidance group of this survey and the LEI project team, resulting in an advisory report to the province of Flevoland. See section 7.2. 


\section{$1 \quad$ Inleiding}

\section{$1.1 \quad$ Aanleiding}

De provincie Flevoland heeft aangegeven dat er behoefte is aan een nieuwe Landbouwverkenning voor haar grondgebied. Na de recente provinciale verkiezingen acht men een dergelijke verkenning van belang ter voorbereiding op de nieuwe Omgevingsvisie, de uitwerking van de Agenda Vitaal Platteland en de voorbereiding van de nieuwe Economische Visie.

\subsection{Probleemstelling}

In 2001 heeft LEI Wageningen UR voor de provincie een Landbouwvisie geschreven met de stand van zaken in de agrarische sector in Flevoland en de belangrijkste trends. Er is nu behoefte aan een update. Er zijn tal van ontwikkelingen die de provincie graag helder in beeld wil hebben, mede om af te kunnen wegen of op bepaalde ontwikkelingen beleid ontwikkeld en ingezet moet worden. Gaat bijvoorbeeld de melkveehouderij in Flevoland groeien en komen er dan meer megastallen en gelijktijdig minder koeien in de wei? Wat betekent dat voor de leefbaarheid van het platteland? Welk perspectief is er voor de akkerbouw in gebieden met bodemdaling? Zijn er voldoende opvolgers voor de bedrijven, enzovoort? Welke rol zou de provincie bij die ontwikkelingen kunnen en willen spelen, ook gezien het speelveld dat deels door de Europese en nationale overheden aan de ene kant en gemeentelijke overheden en waterschappen aan de andere kant wordt bepaald?

\subsection{Doelstelling}

Het doel van deze Landbouwverkenning is dat de provincie een helder beeld krijgt van:

- de stand van zaken van de agrarische sector in Flevoland, ook in vergelijking met andere provincies, nu en in de toekomst

- een benchmark met vergelijkbare regio's

- de belangrijkste ontwikkelingen in en buiten de sector die invloed zullen hebben op de toekomst van de sector zelf, en

- het toekomstperspectief van de Flevolandse landbouw voor de komende tien jaar. Daarnaast wil de provincie graag een 'inspirerend' advies van het LEI naar aanleiding van deze inzichten.

\subsection{Aanpak}

Er zijn verschillende activiteiten uitgevoerd c.q. methodieken gebruikt om de gevraagde resultaten op te kunnen leveren. Per onderdeel ging het daarbij om de volgende inzet:

1. Het opstellen van een thermometer van de huidige Flevolandse land- en tuinbouw: voor dit onderdeel zijn vooral databronnen geraadpleegd om de gewenste indicatoren over structuur en prestatie van de sector in beeld te brengen. Daarbij ging het onder andere om de Landbouwtelling en het Bedrijveninformatienet van het LEI.

2. Het opstellen van een benchmark met vergelijkbare regio's in ons land: in dit onderdeel is een soortgelijke aanpak als in onderdeel 1 toegepast en in de praktijk zijn beide onderdelen in dit rapport geïntegreerd weergegeven in hoofdstuk 2 .

3. Het agrocluster is in beeld gebracht door de resultaten van de nationale agrarische inputoutputtabel, gebruik makend van LISA-gegevens, te verbijzonderen naar Flevoland.

4. Het identificeren van verwachte trends en ontwikkelingen: een workshop met LEI-deskundigen en literatuurstudie vormden in deze fase de belangrijkste activiteiten. 
5. Het schetsen van het toekomstperspectief voor de komende 10 jaar: idem.

6. Advies aan de provincie: uit de onderdelen 1 tot en met 5 zijn door het projectteam in een brainstormsessie punten van aandacht naar voren gehaald, waarmee de provincie haar voordeel zou kunnen doen. Deze zijn verwoord in de aanbevelingen in hoofdstuk 7. 


\section{Structuurverkenning}

\section{$2.1 \quad$ Inleiding}

Dit hoofdstuk beschrijft de structuur van de agrarische sector in Flevoland en de ontwikkelingen die daarin de afgelopen jaren hebben plaatsgevonden. Na een schets van het totaalbeeld van de arealen voor de verschillende sectoren in Flevoland gaan we in op de stand van zaken en de ontwikkelingen in die sectoren. Vervolgens wordt aandacht besteed aan de schaalvergroting in de provincie en wordt ook bezien hoe de opvolgingssituatie in de sector eruitziet. We eindigen dit hoofdstuk met een overzicht van de inkomensontwikkeling en de saldi in de verschillende sectoren. In alle gevallen wordt ook een vergelijking gemaakt met de situatie in Nederland als geheel of met andere vergelijkbare landbouwgebieden in Nederland.

\subsection{Totaalbeeld arealen}

De provincie Flevoland is geografisch en qua ontstaansgeschiedenis te onderscheiden in drie polders, de Noordoostpolder (NOP) en Oostelijk en Zuidelijk Flevoland, met het Ketelmeer als scheiding tussen de NOP en de twee andere polders. De grond in Oostelijk en Zuidelijk Flevoland is gemiddeld zwaarder en vruchtbaarder dan in de NOP. Maar ook de verkaveling is wezenlijk verschillend, omdat de ontstaansperiode verschilt en daarmee de visie op wat landbouwkundig gezien een perspectiefvolle bedrijfsoppervlakte zou zijn. Oostelijk en Zuidelijk Flevoland zijn grootschaliger en, mede daardoor, is het bouwplan er extensiever dan in de NOP (Brouwer et al., 2015). Aan het onderscheid tussen deze drie polders wordt in dit rapport geen aandacht besteed.

Flevoland telde in 2014 in totaal 1.768 land- en tuinbouwbedrijven, waarvan 963 akkerbouw-, 299 graasdier-, 164 tuinbouw-, 72 blijvendeteelt- en 58 hokdierbedrijven (Landbouwtelling 2014). Daarnaast kwamen er in dat jaar in de provincie 212 bedrijven voor met combinaties van vee en/of gewassen (gemengde bedrijven).

Tabel 2.1 toont de totale arealen en de procentuele verdeling van het agrarische grondgebruik in de provincie. Akkerbouw neemt de grootste plaats in, gevolgd door veehouderij, met name melkveehouderij. De opengrondstuinbouwsectoren (bloembollen-, fruit-, vollegrondsgroente- en boomteelt) hebben een aandeel in het grondgebruik van ruim $12,5 \%$.

Tabel 2.1

Gewasarealen in Flevoland in 2014

\begin{tabular}{lrr} 
& & Gewasarealen in Flevoland in 2014 \\
Bedrijfstype & Areaal & ha \\
\hline Akkerbouw & 63.940 & 72,1 \\
\hline Veehouderij (inclusief snijmais) & 18.184 & 3.049 \\
\hline Bloembollenteelt & 1.226 & 3,4 \\
\hline Fruitteelt & 1,4 \\
\hline Vollegrondsgroenteteelt & 1.652 & 467 \\
\hline Boomkwekerij & 0,5 \\
\hline Glastuinbouw a) & 160 & 88.678 \\
\hline Totaal & 100 \\
\hline
\end{tabular}

Bron: Landbouwtelling 2014.

a) Het areaal glastuinbouw is in de Landbouwtelling aan de lage kant geschat. We komen hierop terug in paragraaf 4.4. 
Figuur 2.1 toont de arealen van de bedrijfstypen 'akkerbouw', 'melkvee', 'overige graasdieren' (schapen, geiten, zoogkoeien en dergelijke), 'gemengd' (combinaties van bijvoorbeeld akkerbouw- en melkvee-bedrijven), 'intensief' (varkens-, pluimvee-, kalverhouderij), 'glastuinbouw' en 'totaal' in Flevoland.

Bij alle bedrijfstypen is de gemiddelde bedrijfsomvang sinds 2005 gegroeid. Alleen zijn de bedrijven met overige graasdieren gemiddeld kleiner geworden. Deze categorie bedrijven bestaat voor een groot gedeelte uit neven- en hobbybedrijven. Bij hoge grond- en pachtprijzen wordt het interessant om grond af te stoten, gezien de lage saldi per ha op dit bedrijfstype.

Voor alle genoemde bedrijfstypen blijkt in alle drie weergegeven jaren (2005, 2010 en 2014) het gemiddelde bedrijfsareaal in Flevoland groter dan voor Nederland als geheel (Bijlage 1). Voor melkvee is dat ongeveer $20 \%$, voor akkerbouw $40 \%$, maar de glastuinbouwbedrijven en de intensieve veebedrijven (hoewel klein in aantal in Flevoland) zijn respectievelijk anderhalf en twee keer zo groot als gemiddeld in Nederland. Voor alle sectoren samen is het bedrijfsareaal in Flevoland gemiddeld ongeveer $80 \%$ groter dan in Nederland als geheel. Dat betekent dat de bedrijven in Flevoland gemiddeld veel grond in gebruik hebben, inclusief de intensieve veebedrijven, die meestal tot de nietgrondgebonden sectoren worden gerekend. Bij de overige graasdierbedrijven is het verschil tussen Flevoland en Nederland sinds 2005 geringer geworden.

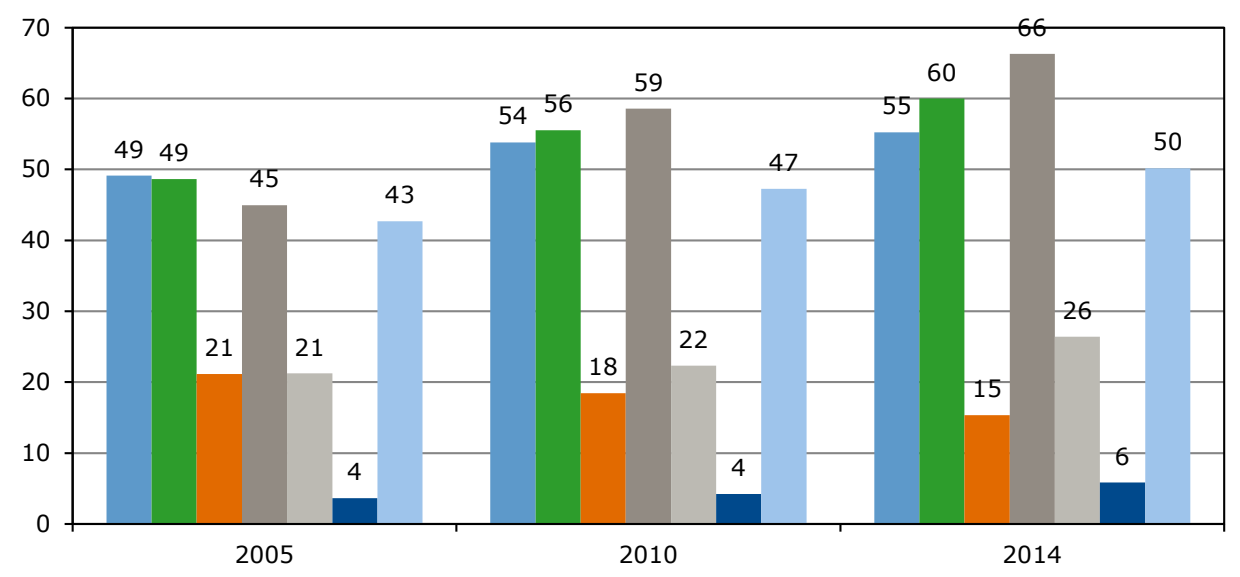

घakkerbouw $\square$ melkvee $\square$ overige graasdieren $\square$ gemengd $\square$ intensief $\square$ glastuinbouw $\square$ totaal

Figuur 2.1 Ontwikkeling arealen per bedrijf naar bedrijfstype in Flevoland

\subsection{Akkerbouw en vollegrondsgroenteteelt}

De akkerbouw is de belangrijkste tak binnen de Flevolandse agrarische sector. Ruim 70\% van de landbouwgrond is in gebruik voor akkerbouwgewassen, waarvan de traditionele gewassen (aardappelen, granen, suikerbiet en uien) veruit de belangrijkste zijn (Tabellen 2.1 en 2.2). Het bouwplan op de Flevolandse akkerbouwbedrijven kan worden gekarakteriseerd als 'intensief'. Dat wil zeggen dat het aandeel hakvruchten en groentegewassen aanmerkelijk hoger is dan in andere delen van Nederland, ten koste van het aandeel granen, gras en snijmais. De gewassen aardappelen, suikerbiet, uien en peen vergen veel van de grond, onder andere door de mate waarin de grond qua mineralen en organische stof uitgeput wordt en de intensiteit waarmee de bodem bereden en bewerkt wordt. Deze gewassen nemen ongeveer $60 \%$ van het bouwplan van de Flevolandse akkerbouwbedrijven in beslag; ongeveer tweemaal zoveel als op het gemiddelde Nederlandse akkerbouwbedrijf. Het aandeel granen en grasland is in Flevoland op de bedrijven ongeveer 30\% tegenover bijna $50 \%$ gemiddeld in Nederland (Tabel 2.2). 
Tabel 2.2

Bouwplan akkerbouwbedrijven in Flevoland en Nederland in 2014

\begin{tabular}{lrr} 
Gewas & Aandeel in bouwplan (\%) in: & Flevoland \\
Consumptieaardappel & 16,1 & 1,0 \\
\hline Pootaardappel & 13,1 & 7,2 \\
\hline Suikerbiet & 14,2 & 12,0 \\
\hline Granen & 24,5 & 30,8 \\
\hline Zaaiui & 13,5 & 4,0 \\
\hline Winterpeen & 4,9 & 1,0 \\
\hline Grasland en snijmais & 3,8 & 16,3 \\
\hline Bloembollen & 0,0 & 1 \\
\hline Overige gewassen a) & 9,9 & 17,7 \\
\hline Totaal & 100 & 100 \\
\hline
\end{tabular}

Bron: Landbouwtelling 2014

a) Waaronder overige akkerbouwgewassen.

In de Noordoostpolder is het bouwplan nog intensiever dan in Oostelijk en Zuidelijk Flevoland. Naast de traditionele gewassen worden daar ook pootaardappelen, vollegrondsgroenten en bloembollen geteeld. ${ }^{1}$ De hoge intensiteit brengt risico's met zich mee voor onder andere het organischestofgehalte, de bodemstructuur, de bodemgezondheid (aardappelcyste- en vrijlevende aaltjes) en de waterregulering. Granen en gras daarentegen bevorderen een goede doorworteling van de grond en laten per saldo organische stof achter in de bodem.

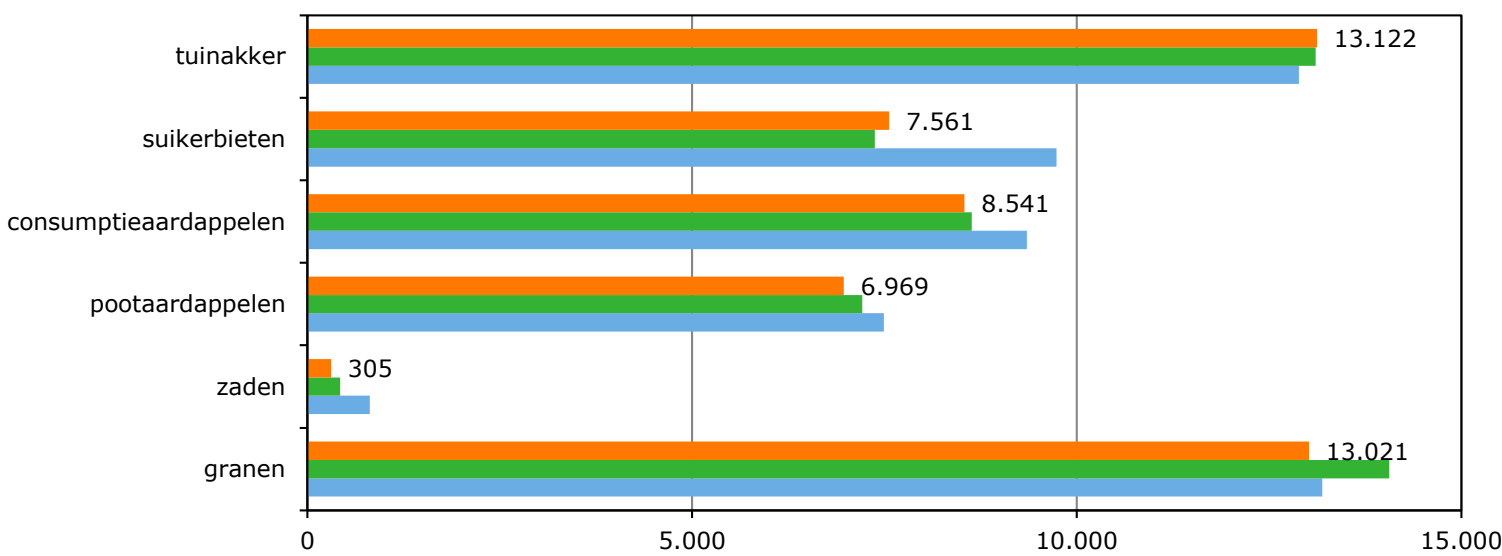

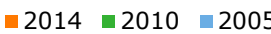

Figuur 2.2 Areaal akkerbouwgewassen op akkerbouwbedrijven a) in Flevoland in 2005, 2010 en 2014

Bron: Landbouwtelling 2014.

a) Inclusief akkerbouwmatig geteelde akkerbouwgewassen ('tuinakker'), exclusief bloembollen (zie paragraaf 2.4) en exclusief de arealen groenbemestingsgewassen, akkerranden en dergelijke, gewassen zonder marktbare opbrengst.

\footnotetext{
${ }^{1}$ In Oostelijk en Zuidelijk Flevoland wordt overigens ook grond voor bloembollenteelt verhuurd ('reizende bollenkraam') en is er nog een areaal conserventeelt.
} 
Uit Figuur 2.2 is op te maken dat het bouwplan op de akkerbouwbedrijven in Flevoland de afgelopen jaren redelijk stabiel gebleven is. De meest opvallende verandering is de krimp van het suikerbietenareaal. Dit is veroorzaakt door een sterke structurele verhoging van de suikeropbrengsten per ha, zodat minder areaal nodig was om het suikerquotum vol te produceren. De vrijkomende oppervlakte is met name ingenomen door tuinbouwgewassen (grotendeels bestaande uit uien, winterpeen, conserventeelten en bloembollen) en granen.

Tabel 2.3 toont de ontwikkeling van het aantal akkerbouwbedrijven in Flevoland en twee vergelijkbare gebieden, de Noordelijke en Zuidwestelijke kleigebieden. In Flevoland bevonden zich in 2014 nog een kleine 1.000 akkerbouwbedrijven, 20\% minder dan in 2005. Die afname is sterker geweest dan in het Noordelijk (15\%) en het Zuidwestelijk (9\%) akkerbouwgebied. Dat betekent tegelijkertijd dat de schaalvergroting in Flevoland het afgelopen decennium sneller is verlopen dan in de twee andere regio's. Dit blijkt ook uit Bijlage 1, waarin de index van Flevoland ten opzichte van Nederland in de akkerbouw over de drie weergegeven jaren is toegenomen.

\section{Tabel 2.3}

Ontwikkeling aantal akkerbouwbedrijven in Flevoland en twee andere akkerbouwregio's op klei in de periode $2005-2014$

\begin{tabular}{|c|c|c|c|c|}
\hline \multirow[t]{2}{*}{ Regio } & \multicolumn{4}{|c|}{ Aantal akkerbouwbedrijven in: } \\
\hline & 2005 & 2010 & 2014 & 2014 (in \% van 2005) \\
\hline Noordelijk kleigebied & 1.092 & 985 & 926 & 85 \\
\hline Flevoland akkerbouw & 1.205 & 1.027 & 963 & 80 \\
\hline
\end{tabular}

Bron: CBS-landbouwtelling.

\subsection{Tuinbouw}

Ruim $10 \%$ van de oppervlakte in Flevoland wordt gebruikt voor tuinbouwgewassen, in volgorde: bloembollen, vollegrondsgroenten, fruitteelt (pit-/steenvruchten), boomteelt en een kleine tak bedekte teelten (glasgroente (tomaat, paprika, komkommer) en bloemen- en potplantenteelt).

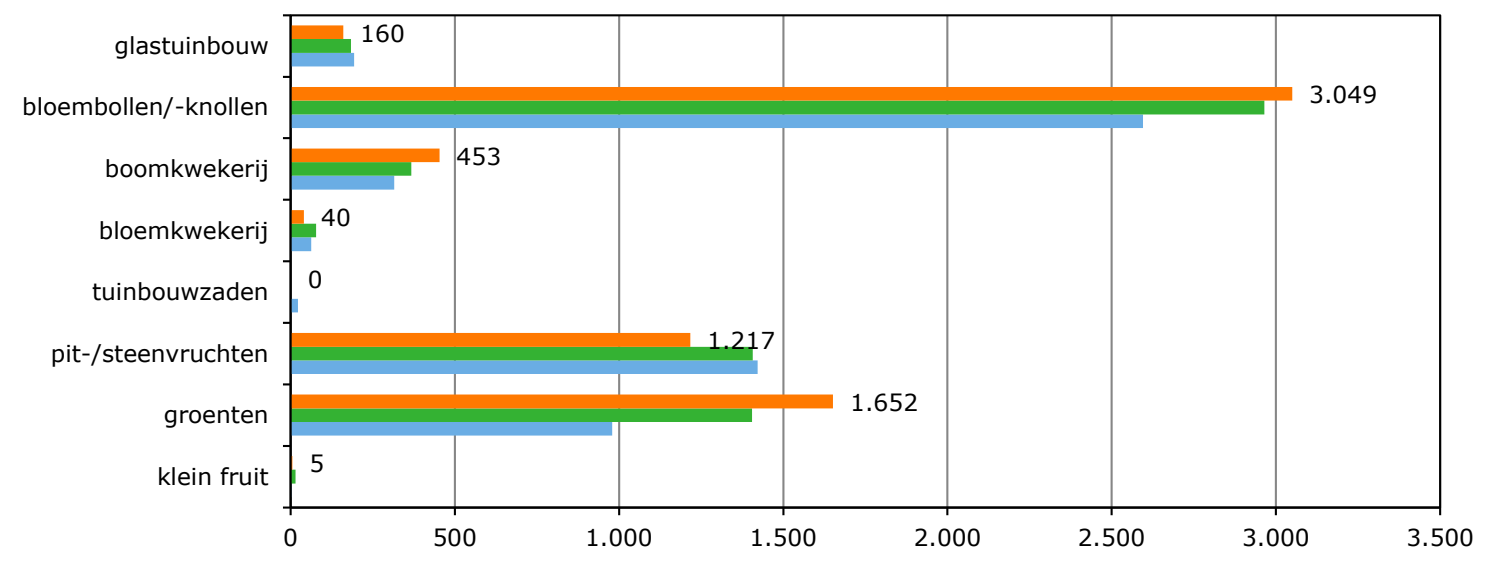

$\square 2014 \square 2010 \quad 2005$

Figuur 2.3 Arealen tuinbouwsectoren in Flevoland in 2005, 2010 en 2014

Bron: Landbouwtelling, CBS. 
Flevoland speelt een belangrijke rol in de primaire productie van bloembollen. Voor tulpen, gladiolen, lelies en tal van andere bolgewassen is vooral de Noordoostpolder een erg belangrijk productiegebied. Het gebied kenmerkt zich door efficiënte, grote bedrijven. Contractteelt komt regelmatig voor. De bollen op kleigronden zijn voornamelijk bestemd voor de broei (citaat op de website van de KAVB, de Koninklijke Algemeene Vereeniging voor Bloembollencultuur, www.kavb.nl/kringen/kring/?thema=8, geraadpleegd op 21-10-2015).

\subsection{Melkvee- en graasdierhouderij}

In 2014 liepen er in Flevoland ruim 28.000 melkkoeien en ongeveer 20.000 stuks jongvee rond (Figuur 2.4). Die aantallen zijn duidelijk groter dan in 2010 en 2005 . Tegelijkertijd is het aantal bedrijven in Flevoland ten opzichte van 2005 aanzienlijk gedaald, namelijk met 9\% (Tabel 2.4).

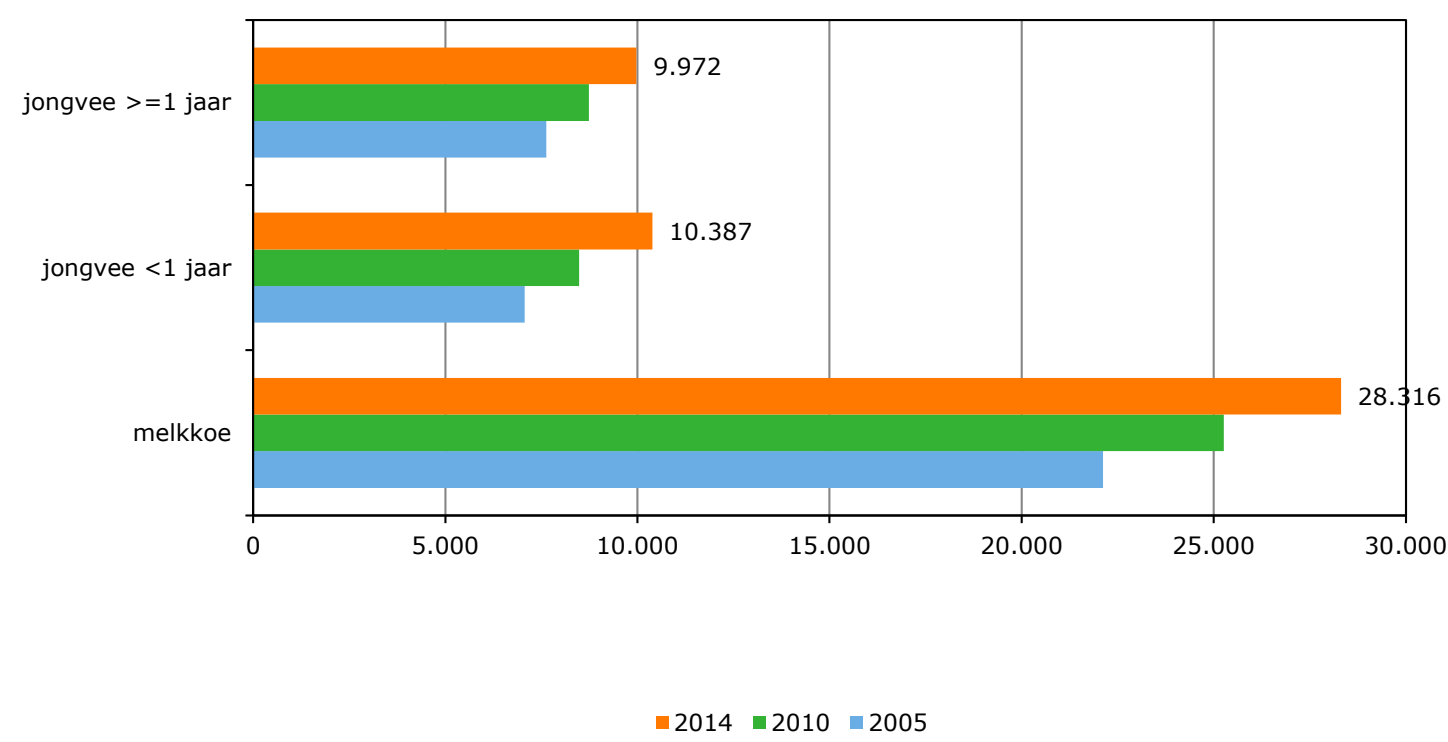

Figuur 2.4 Ontwikkeling veestapel in Flevoland op melkveebedrijven in 2005, 2010 en 2014 Bron: CBS-Landbouwtelling.

\section{Tabel 2.4}

Ontwikkeling aantal melkveebedrijven in Flevoland en Noord-Nederland 2005-2014

\begin{tabular}{lrrrr} 
Gebied & \multicolumn{5}{c}{ Aantal melkveebedrijven in: } \\
\cline { 2 - 5 } Noord-Nederland & 2005 & 2010 & 2014 & 2014 (in \% van 2005) \\
\hline Flevoland & 1.909 & 2.163 & 2.337 & 216 \\
\hline
\end{tabular}

Bron: CBS-landbouwtelling.

De daling van het aantal melkveebedrijven in Flevoland is overigens kleiner dan bij de akkerbouwbedrijven in de provincie. In Noord-Nederland is het aantal melkveebedrijven sinds 2005 juist toegenomen door instroom vanuit andere delen van Nederland (maar niet vanuit Flevoland). 
$\mathrm{Na}$ de akkerbouw is de melkveehouderij de tweede grondgebruiker (20\% van de oppervlakte voor gras en snijmais, Tabel 2.1) in Flevoland. De melkveehouderij heeft hierbij een duidelijke verbinding met de akkerbouw. Vooral grondruil komt veel voor. ${ }^{2}$ Voor de veehouderij is het voordeel daarbij dat er meer oppervlakte benut kan worden voor de (ruw)voerproductie. Voor de akkerbouw is grasland een welkom element in de vruchtwisseling. De melkveehouderij in Flevoland is ook intensief. Dat wil zeggen dat veel bedrijven een betrekkelijk hoge melkproductie per ha realiseren.

In Figuur 2.5 is de gemiddelde melkproductie per koe in Flevoland weergegeven. In alle weergegeven jaren was de melkproductie per koe in Flevoland ongeveer 300 à 400 kg per jaar hoger dan gemiddeld in Nederland. Dat verschil varieert per jaar maar lijkt niet af te nemen.

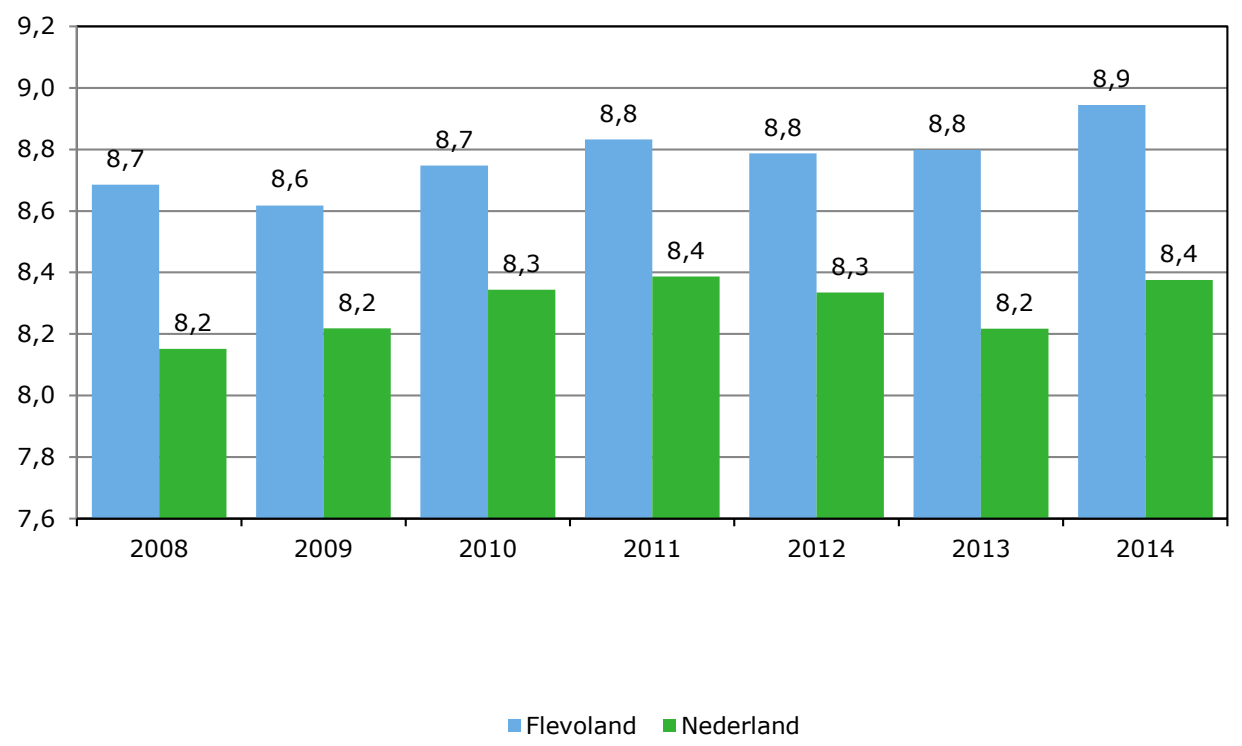

Figuur 2.5 Melkproductie (x $1.000 \mathrm{~kg})$ per koe (2008-2014)

Bron: CRV (www.crv4all.nl).

Van minder groot economisch belang ${ }^{3}$ is de 'overige graasdierhouderij' in de provincie Flevoland. Het aantal schapen en geiten is weergegeven in Tabel 2.5. Sinds 2005 is het aantal lammeren en schapen met een derde gedaald. Het aantal geiten is de afgelopen tien jaar verviervoudigd.

\section{Tabel 2.5}

Ontwikkeling van het aantal lammeren en schapen enerzijds en het aantal geiten anderzijds in de provincie Flevoland

\begin{tabular}{lcr} 
Jaar & Lammeren en schapen & Geiten \\
2004 & 13.615 & 1.409 \\
\hline 2005 & 15.478 & 1.456 \\
\hline 2008 & 13.583 & 2.068 \\
\hline 2010 & 13.608 & 3.007 \\
\hline 2012 & 11.346 & 5.272 \\
\hline
\end{tabular}

Bron: CBS, Landbouwtelling.

2 De mate waarin grondruil voorkomt, is moeilijk te kwantificeren, omdat deze niet altijd op papier vastgelegd wordt en opgegeven in de Basis Registratie Percelen (BRP).

3 Uiteraard kan deze tak voor individuele bedrijven wel van groot economisch belang zijn. Daarnaast spelen met name schapen een rol bij dijkbeheer en dragen ze bij aan de landschappelijke kwaliteit van Flevoland. 


\subsection{Intensieve veehouderij}

Het totaal aantal gespecialiseerde intensieve veebedrijven is sinds 2005 gestegen van 47 naar 58 (Tabel 2.6). Die groei is vooral van toepassing bij de bedrijven met vleesvarkens en leghennen. In de andere subsectoren is de trend stabiel tot dalend.

Tabel 2.6

Aantal gespecialiseerde intensieve veebedrijven in Flevoland

\begin{tabular}{|c|c|c|c|}
\hline Bedrijfstype & \multicolumn{3}{|c|}{ Aantallen in jaar } \\
\hline Totaal intensief & 47 & 53 & 58 \\
\hline vleesvarkens & 3 & 4 & 10 \\
\hline gesloten varkens a) & 4 & 1 & 2 \\
\hline vleeskuikens & 11 & 12 & 11 \\
\hline overig pluimvee & 11 & 14 & 11 \\
\hline overige hokdieren b) & 2 & 4 & 4 \\
\hline
\end{tabular}

Bron: CBS-landbouwtelling in diverse jaren.

a) Bedrijven waar zowel de vermeerdering als het mesten van varkens plaatsvindt.

b) Vleeskalveren, eenden, konijnen, nertsen en dergelijke.

De aantallen dieren op deze bedrijven zijn vermeld in Tabel 2.7. Vooral het aantal leghennen is in het laatste decennium sterk toegenomen en bedraagt nu 1,5 miljoen. Maar ook het aantal vleesvarkens is vrijwel verdubbeld tot 19.000 , terwijl het aantal fokvarkens stabiliseert op 5.000 dieren. De afgelopen jaren worden geen kalkoenen meer gehouden in Flevoland, maar het aantal eenden is na een daling in 2010 nu bijna weer op het niveau van 2005 (85.000 dieren). Het aantal vleeskuikens is sinds 2010 gedaald en stond in 2014 op 461.000 stuks.

Zowel in 2010 als 2014 waren er drie intensieve veehouderijbedrijven met een biologische in de bedrijfsvoering of, in het geval van leghennen, met vrije uitloop.

Tabel 2.7

Aantallen dieren op de gespecialiseerde intensieve veebedrijven in Flevoland

\begin{tabular}{lrrr} 
Bedrijfstype & \multicolumn{3}{c}{ Aantallen in jaar } \\
\cline { 2 - 4 } Aantal hokdierbedrijven & 2005 & 2010 & 2014 \\
\hline Waarvan biologisch & 45 & 49 & 54 \\
\hline Aantal leghennen $(* 1.000)$ & 1 & 3 & 3 \\
\hline Aantal vleeskuikens $(* 1.000)$ & 777 & 1.113 & 1.546 \\
\hline Aantal vleesvarkens $(* 1.000)$ & 361 & 508 & 461 \\
\hline Aantal fokvarkens $(* 1.000)$ & 10 & 15 & 19 \\
\hline Aantal kalkoenen $(* 1.000)$ & 3 & 6 & 5 \\
\hline Aantal eenden $(* 1.000)$ & 5 & 0 & 0 \\
\hline
\end{tabular}

Bron: CBS-landbouwtelling.

\subsubsection{Varkenshouderij}

De productieketen van varkensvlees in Nederland bestaat uit een groot aantal schakels. De meest in het oog springende schakels zijn de veevoerindustrie, de varkensfokkerij, de varkenshouderij, de vleesindustrie en de retail. Aanverwante actoren die tot het cluster behoren, zijn bijvoorbeeld 
stalbouwers, veehandelaren, logistiek dienstverleners en transporteurs, auditors en certificerende instellingen, kwaliteitsborging, dierenartsen, adviseurs, accountants, banken en onderzoek. Deze zijn niet uitsluitend gericht op het varkenscluster maar ook gerelateerd aan andere productietakken. Daarnaast zijn er ook gelieerde activiteiten zoals overheden en toezichthouders, levensmiddelenindustrie (afzet bijproducten) en ngo's. Ten slotte zijn er actoren die fungeren als koepel en vertegenwoordiging van meerdere gelijksoortige spelers. De omvang van de productstromen is weergegeven in Figuur 2.6.



Figuur 2.6 De varkensproductieketen in Nederland, 2014 a)

Bronnen: CBS, Nevedi, OPNV, PVE, bewerking LEI.

a) Productie, verbruik en im- en export op basis van 2012; Berkhout et al. (2015a); b) Alleen Nevedileden; c) Vochtrijke diervoeders, enkelvoudige voeders, premixen en kalvermelk; d) $>100.000$ slachtingen per jaar.

\subsubsection{Pluimveehouderij}

De productie van pluimveevlees vindt plaats in een productieketen met daarin meerdere opeenvolgende schakels die elk een gespecialiseerde taak voor hun rekening nemen. De keten is een samenspel van specialismen waarin fokkerij, vermeerderaar, broederij, pluimveehouder en slachter/verwerker samenwerken. Figuur 2.7 (Figuur 3.5 uit Berkhout et al., 2015b) geeft de hoofdlijnen van de keten. In de top van de keten staan de reproductiebedrijven (vermeerdering) die broedeieren produceren die vervolgens in gespecialiseerde broederijen worden uitgebroed tot eendagskuikens. Daarna worden de eendagskuikens bij vleeskuikenhouders gehouden tot een gewicht van 1,8 tot $2,6 \mathrm{~kg}$ om vervolgens getransporteerd te worden naar een pluimveeslachterij (citaat uit Berkhout et al., 2015b). 


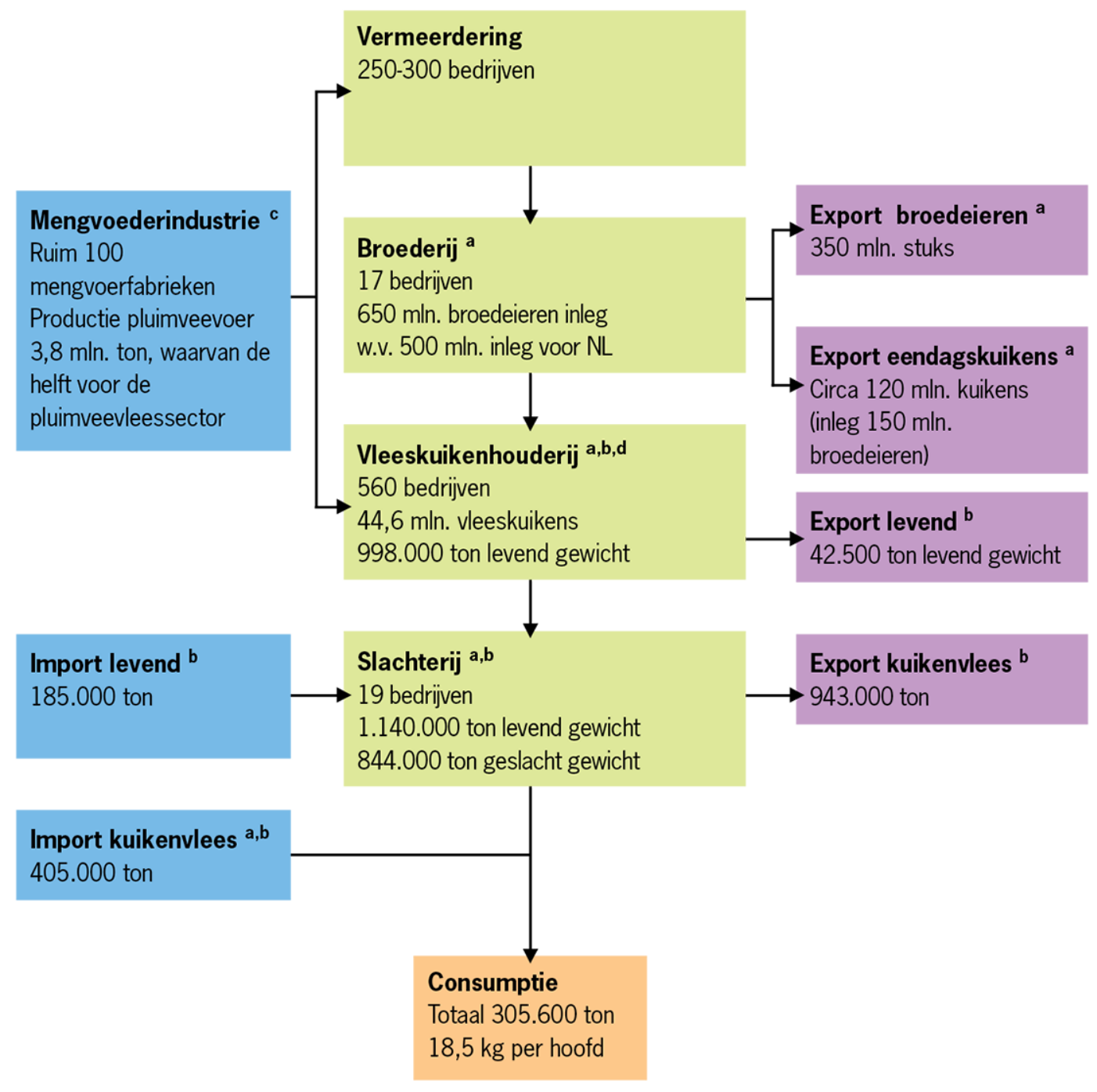

Figuur 2.7 De keten rond de vleeskuikenhouderij, 2012/2013

a) PPE, 2013; b) PVE, 2013; c) Nevedi; d) LEI/CBS Landbouwtelling, 2013.

\subsection{Aantal bedrijven en schaalgrootte}

De schaalvergroting in Flevoland in het afgelopen decennium blijkt uit Figuur 2.8. De bedrijfsomvang is uitgedrukt in Standaard Opbrengst, een maat voor de totale omzet van het bedrijf. ${ }^{4}$ De omzet per bedrijf is in alle sectoren aanzienlijk toegenomen sinds 2005. Over de totale sector is de 'economische' omvang toegenomen van $€ 224.000$ naar $€ 324.000$, een stijging van $45 \%$.

\footnotetext{
${ }^{4}$ Meer informatie over de indicator Standaard Opbrengst op www.wageningenur.nl/nl/ExpertisesDienstverlening/Onderzoeksinstituten/LEI/Data-1/Bedrijfsomvang-en-type-1.htm of in LEI-publicatie 15-048). Omdat de SO regelmatig wordt geactualiseerd is de ontwikkeling van deze indicator geen goede maat voor de absolute intensiteitsontwikkeling gedurende de tijd, maar wel kunnen de intensiteitsontwikkelingen tussen de verschillende regio's goed met elkaar worden vergeleken.
} 


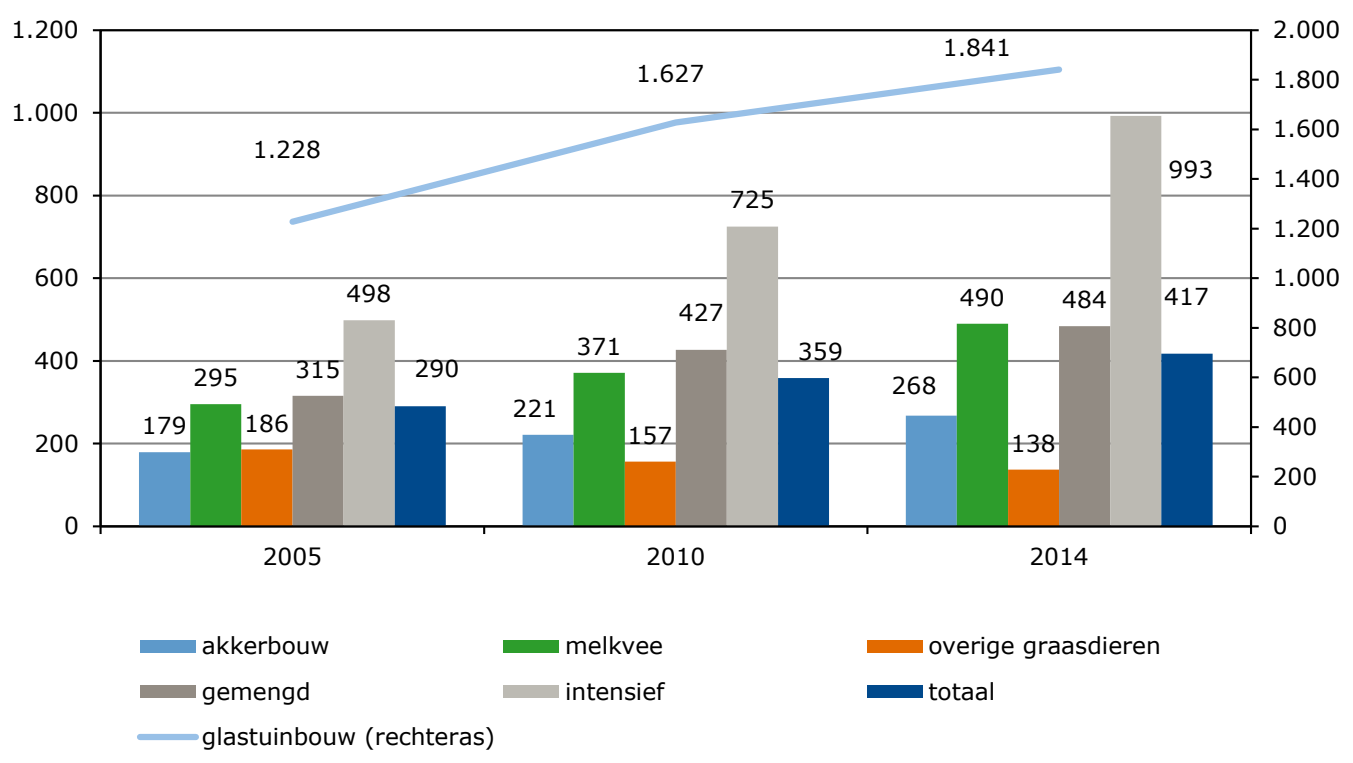

Figuur 2.8 Ontwikkeling bedrijfsomvang (uitgedrukt in Standaardopbrengst) per bedrijfstype in Flevoland ( $x$ 1.000 euro) a)

a) Glastuinbouw heeft een hoge SO-waarde per bedrijf en moet daarom op de rechter-as afgelezen worden.

Uit Figuur 2.8 blijkt dat in Flevoland in tussen 2005 en 2014 de gemiddelde bedrijfsomvang van alle bedrijfstypen toegenomen is, behalve voor de overige graasdieren, waar de omvang met een kwart gedaald is. Gemiddeld was de groei $44 \%$, met uitschieters in de intensieve veehouderij (verdubbeling) en de melkveehouderij (66\%). In de akkerbouw, de glastuinbouw en de gemengde bedrijven was de groei ongeveer $50 \%$. Bijlage 2 toont dat, net als in bedrijfsareaal, de economische bedrijfsomvang in Flevoland groter is dan gemiddeld in Nederland. Voor de totale land- en tuinbouwsector was dat in 2014 ongeveer $25 \%$. In de akkerbouw is de bedrijfsomvang twee keer zo groot dan gemiddeld, in de melkveehouderij bijna 1,5 keer. De schaalvergroting is in Flevoland overigens niet anders geweest dan in Nederland; beide zijn tussen 2005 en 2014 60-65\% groter geworden (in SO gemeten).

In Figuur 2.9 zijn de bedrijven in Flevoland ingedeeld naar grootteklasse en bedrijfstype voor de twee belangrijkste agrosectoren in de provincie, akkerbouw en melkveehouderij. Er heeft een sterke opschuiving naar grotere bedrijfsomvang (meer dan 50 ha) plaatsgevonden. In Figuur 2.10 is die ontwikkeling in Flevoland vergeleken met andere regio's in Nederland, namelijk het Noordelijke en het Zuidwestelijk kleigebied voor de akkerbouwsector en Noord-Nederland voor de melkveehouderij. Het gaat om gebieden die qua bedrijfsstructuur het meest op Flevoland lijken.

Uit deze figuren blijkt dat het aantal grote akkerbouwbedrijven, met meer dan 100 ha cultuurgrond, in Flevoland toeneemt. Procentueel zijn het er in 2014 ongeveer evenveel als in het Zuidwestelijk kleigebied, maar vergelijken met het Noordelijk kleigebied zijn het er minder. Hele kleine akkerbouwbedrijven van minder dan 20 ha komen in Flevoland weinig voor. Vooral de middengroepen zijn in Flevoland sterk vertegenwoordigd. 


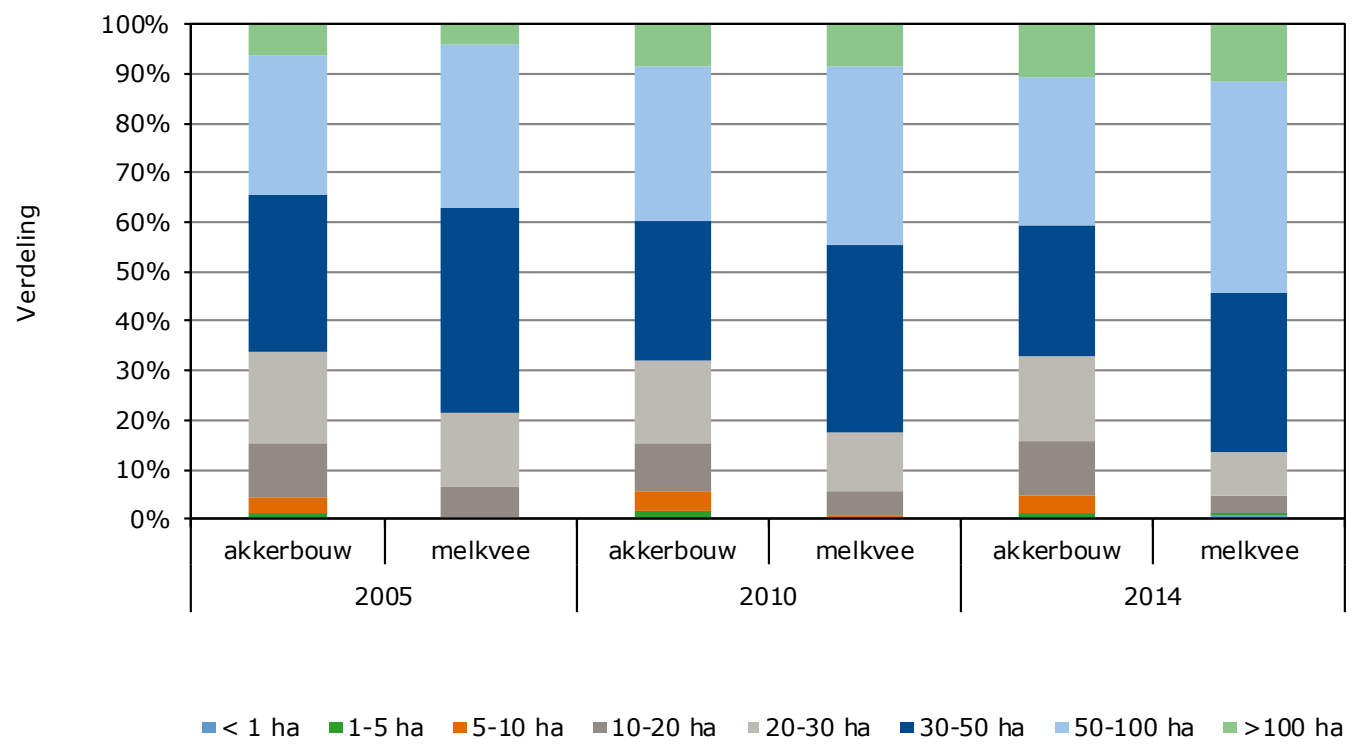

Figuur 2.9 Verdeling (\%) bedrijven naar omvang in hectare naar type in Flevoland, 2005, 2010 en 2014

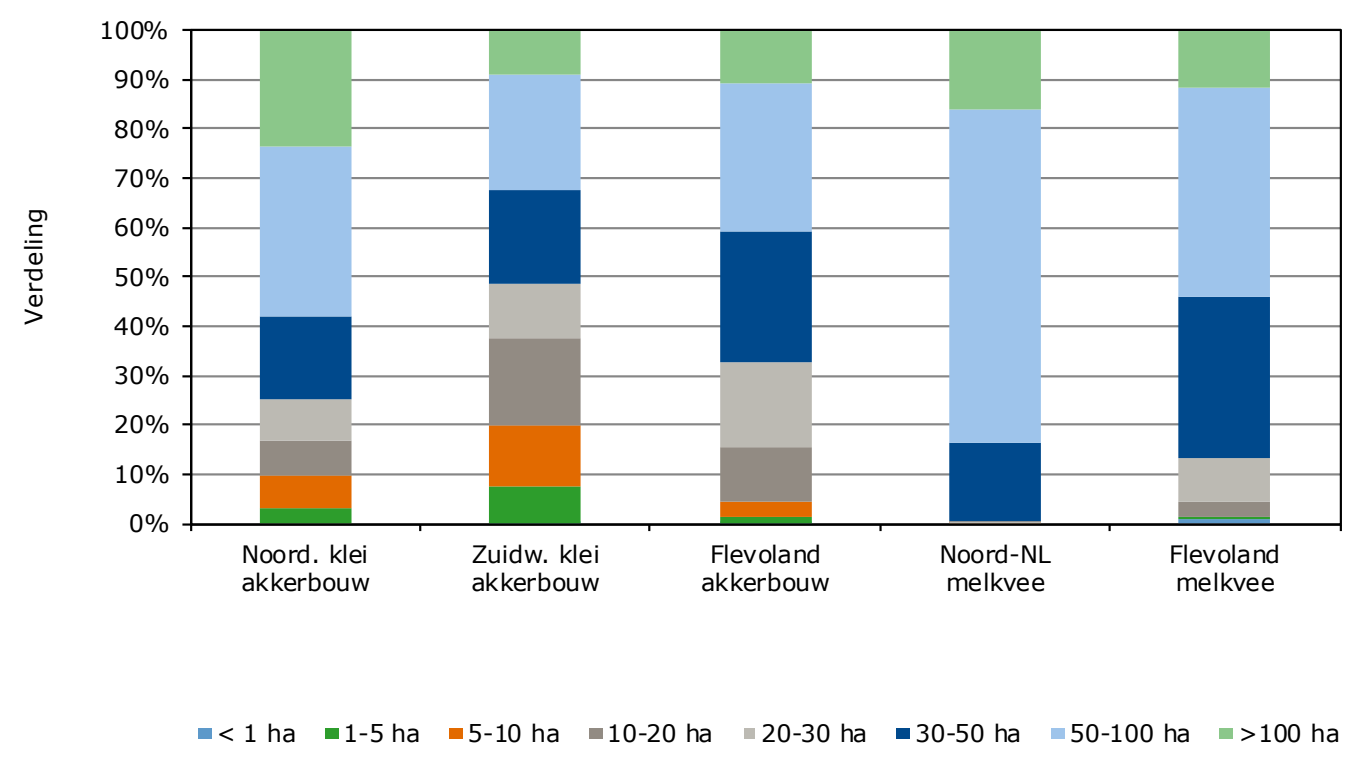

Figuur 2.10 Aantal bedrijven naar omvang in hectare naar type en regio, 2014 (zie Bijlage 5 voor de getallen bij deze figuur)

Bron: Landbouwtelling.

De groep grote Flevolandse melkveebedrijven is kleiner dan in Noord-Nederland, maar groeiende. Ook komen in Flevoland nog vrij veel melkveebedrijven voor met een bedrijfsoppervlakte van minder dan 30 ha. Deze groep bedrijven wordt gestaag kleiner; in Noord-Nederland komen deze kleine bedrijven nauwelijks meer voor. In de Figuur 2.11 gaan we hier nader op in. ${ }^{5}$

$\overline{5}$ Voor een overzicht van het opbrengend vermogen van de grond wordt verwezen naar paragraaf 2.13. 


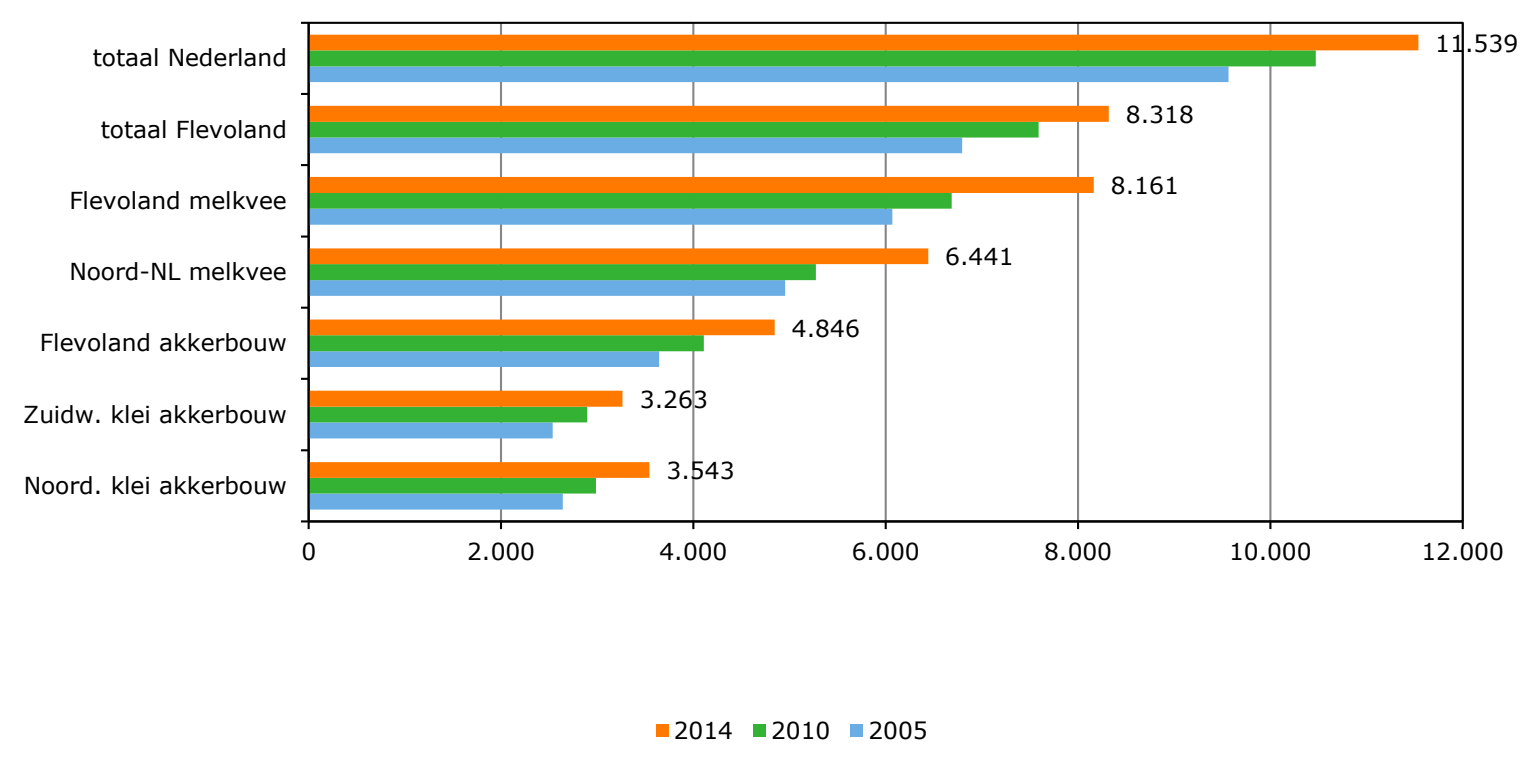

Figuur 2.11 Ontwikkeling van de productie-intensiteit naar bedrijfstype en regio (SO in euro/ha, 2005, 2010 en 2014)

Figuur 2.11 geeft een indicatie van de ontwikkeling van de intensiteit van de akkerbouw- en melkveebedrijven in Flevoland en vergelijkbare regio's. Die intensiteit is gemeten in Standaard Opbrengst (SO) per ha gewas. Te zien is dat de ontwikkeling van de productie-intensiteit in Flevoland ongeveer gelijke tred heeft gehouden met de landelijke ontwikkeling. In de melkveehouderij was de intensiteit hoger dan in Noord-Nederland. De ontwikkeling in intensiteit was bovendien fractioneel sterker. In de praktijk betekent dit dat de melkproductie per hectare op melkveebedrijven in Flevoland gemiddeld hoger is dan in Noord-Nederland en ook iets sneller is toegenomen.

Ook de Flevolandse akkerbouw is intensiever dan in de vergelijkingsgebieden, het Noordelijk kleigebied en het Zuidwestelijk kleigebied. Dat houdt in dat er relatief meer hoogsalderende gewassen - zoals aardappelen, uien, vollegrondsgroenten en bloembollen - in het bouwplan van de Flevolandse akkerbouwbedrijven zijn opgenomen dan in de andere beide gebieden (wat in lijn is met Tabel 2.2).

De beschikbare data geven een stabiel beeld qua aantal melkveebedrijven in Flevoland. Het totaal aantal melkkoeien is sinds 2005 in de provincie met 3\% per jaar gegroeid. Deze groei was ongeveer driemaal zo groot als landelijk gezien het geval was. Ook de omvang van de bijbehorende jongveestapel groeide fors (Figuur 2.4). De verdeling van de melkkoeien over de bedrijven is weergegeven in Figuur 2.12. Het gemiddeld aantal melkkoeien per bedrijf is in Flevoland in de afgelopen tien jaar toegenomen van ongeveer 85 naar 120. In diezelfde periode nam dat aantal voor Nederland als geheel toe van 60 naar 80 dieren per bedrijf.

In het verlengde van de gemiddeld grotere melkveebedrijven in Flevoland is in Figuur 2.13 ook te zien dat het percentage bedrijven met 100 tot 150 melkkoeien of meer zowel in Nederland als Flevoland toeneemt maar in Flevoland in de jaren 2005, 2010 en 2014 duidelijk groter was dan gemiddeld in Nederland. In Flevoland zijn relatief veel melkveebedrijven met weinig areaal (Figuur 2.10); aan de andere kant zijn er weinig bedrijven met minder dan 50 koeien (Figuur 2.13). De productieomvang is in Flevoland dus niet kleiner (zelfs groter volgens Figuur 2.12). Dit levert het beeld op dat de melkveebedrijven in Flevoland intensiever zijn dan elders. Dit is uitgebeeld in Figuur 2.14. Het aandeel hoge intensiteit ( 3 tot 4,5 of meer dan 4,5 gve/ha) is in Flevoland ongeveer $45 \%$ tegenover $25 \%$ in Nederland. Bovendien is er een (klein) aandeel zonder grond, wat op Nederlands niveau procentueel verwaarloosbaar is. De melkveehouderij in Flevoland lijkt dus minder grondgebonden dan elders.

Hierbij past wel de kanttekening dat het zou kunnen gaan om gemengde bedrijven met twee aparte bedrijfsnummers, één voor de melkveestal en één voor de grond. Daardoor lijkt het alsof het gaat om 
grondloze melkveebedrijven, maar de ruwvoervoorziening vindt in feite plaats op het akkerbouwdeel van het gecombineerde bedrijf.

Voor grotere melkveebedrijven is het gemiddeld lastiger om beweiding toe te passen dan voor kleinere bedrijven. Uit Figuur 2.15 blijkt dat in Flevoland 70\% van de koeien niet geweid worden tegenover een kwart in Nederland. Nog geen $10 \%$ weidt dag en nacht tegenover $20 \%$ gemiddeld in Nederland.

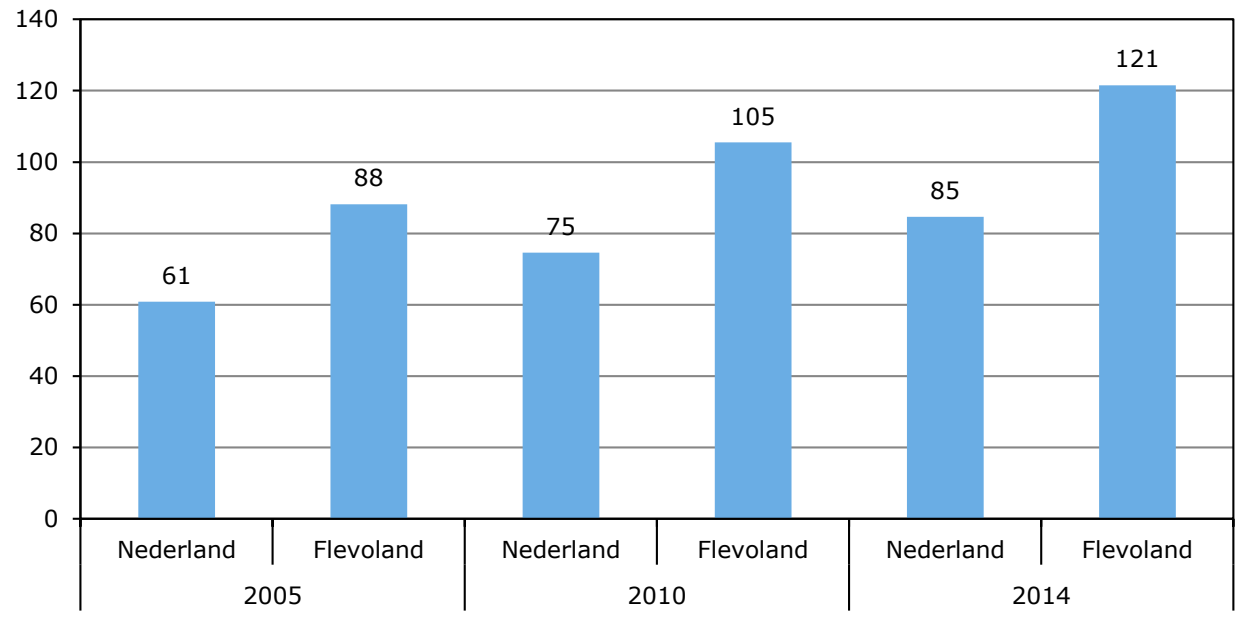

Figuur 2.12 Ontwikkeling aantal koeien per bedrijf in Nederland en Flevoland in 2005, 2010 en 2014

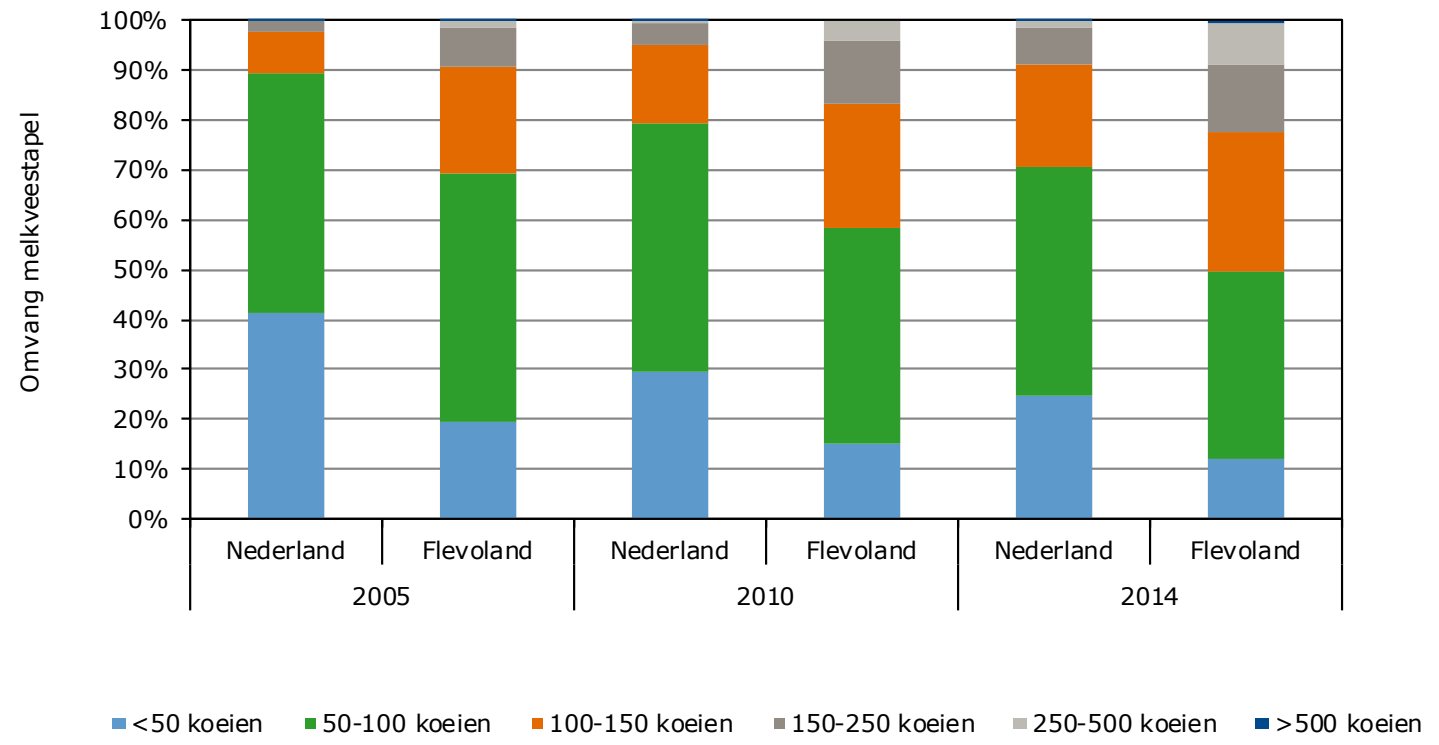

Figuur 2.13 Aantal bedrijven naar omvang melkveestapel (\%) in Flevoland en Nederland in 2005, 2010 en 2014 




Figuur 2.14 Opbouw rundveestapel naar intensiteitsklasse in Flevoland en Nederland in 2014 (uitgedrukt in gve (grootvee-eenheden))

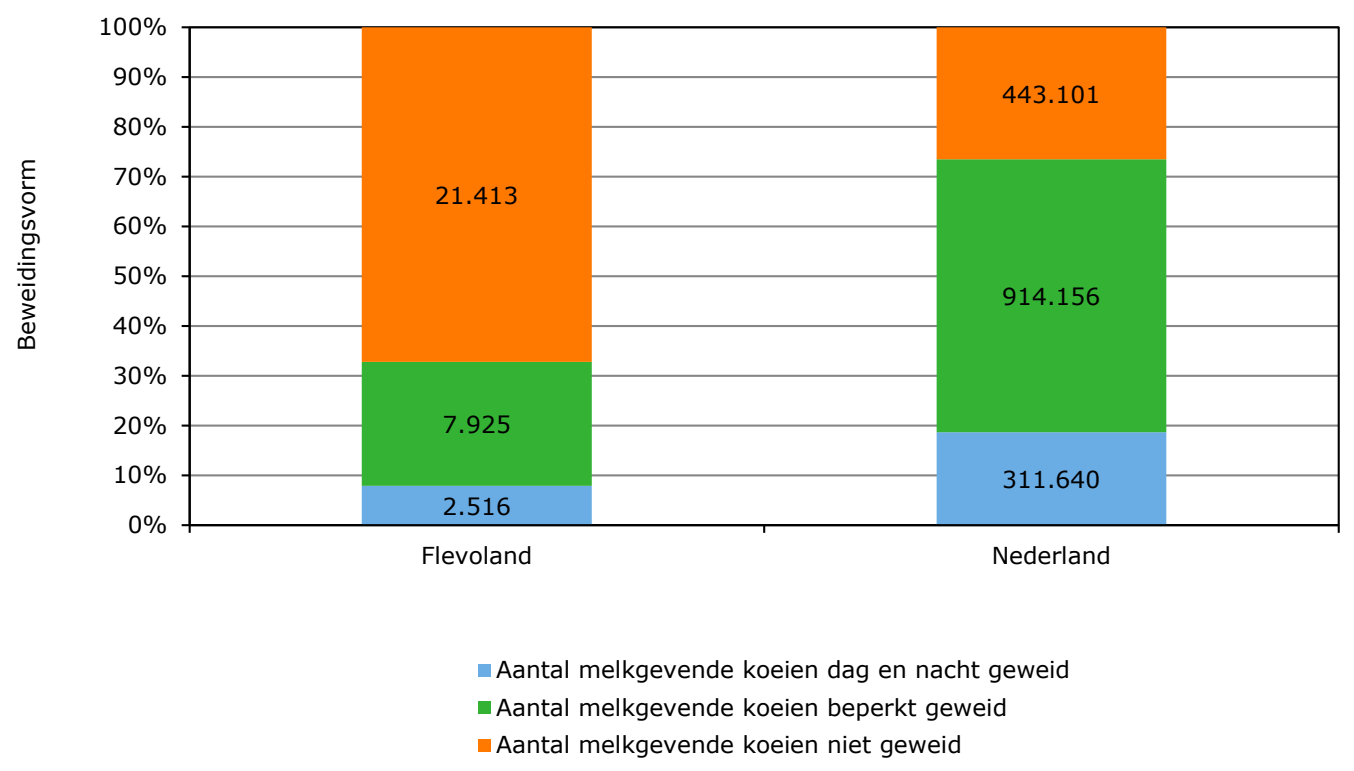

Figuur 2.15 Aantal melkgevende koeien in Flevoland en Nederland naar beweidingsvorm in 2013 


\subsection{Opvolgingssituatie en positie van gezinsbedrijven in Flevoland}

De leeftijdsopbouw van het oudste agrarische bedrijfshoofd ${ }^{6}$ is in Flevoland vergelijkbaar met die op andere bedrijven in Nederland: ongeveer $50 \%$ van de bedrijfshoofden is ouder dan 50 jaar

(Figuur 2.16). De opvolgingsbereidheid is in Flevoland relatief gunstiger. Het percentage bedrijven met een bedrijfshoofd ouder dan 50 jaar zonder opvolger ligt in Flevoland op 30\% tegenover bijna $40 \%$ in Nederland totaal (2012). Op melkveebedrijven is de opvolgingsbereidheid groter dan op akkerbouwbedrijven.



Figuur 2.16 Leeftijd en opvolgingssituatie in Flevoland naar bedrijfstype in 2004, 2008 en $2012^{7}$

De vraag hoe het gezinsbedrijf zich ontwikkelt, vraagt een begripsdefinitie. Gangbaar is om een gezinsbedrijf te typeren als een bedrijf waarvan de factoren arbeid en kapitaal door de ondernemer(s) en zijn/hun gezin worden geleverd. Voor wat betreft de factor arbeid zijn de bedrijven in Figuur 2.17 ingedeeld naar de relatieve hoeveelheid arbeid die niet door de ondernemer(s) en zijn gezinsleden wordt geleverd. Daarvoor zijn drie categorieën benoemd. In de eerste categorie wordt vrijwel alle arbeid door het gezin geleverd en hooguit $10 \%$ door zogenoemde 'vreemde arbeidskrachten'. In de derde categorie wordt meer dan $50 \%$ van de totale arbeid verricht door vreemde arbeidskrachten. De tweede categorie bestaat uit bedrijven die daar tussen in liggen: 10\% tot maximaal 50\% van de arbeid wordt geleverd door vreemde arbeidskrachten.

\footnotetext{
6 De leeftijd van het oudste bedrijfshoofd wordt in de Landbouwtelling gevraagd. Als hij of zij ouder is dan 50 jaar, wordt ook gevraagd naar de aanwezigheid van een bedrijfsopvolger.

7 De opvolgingssituatie wordt iedere vier jaar in de Landbouwtelling gevraagd.
} 


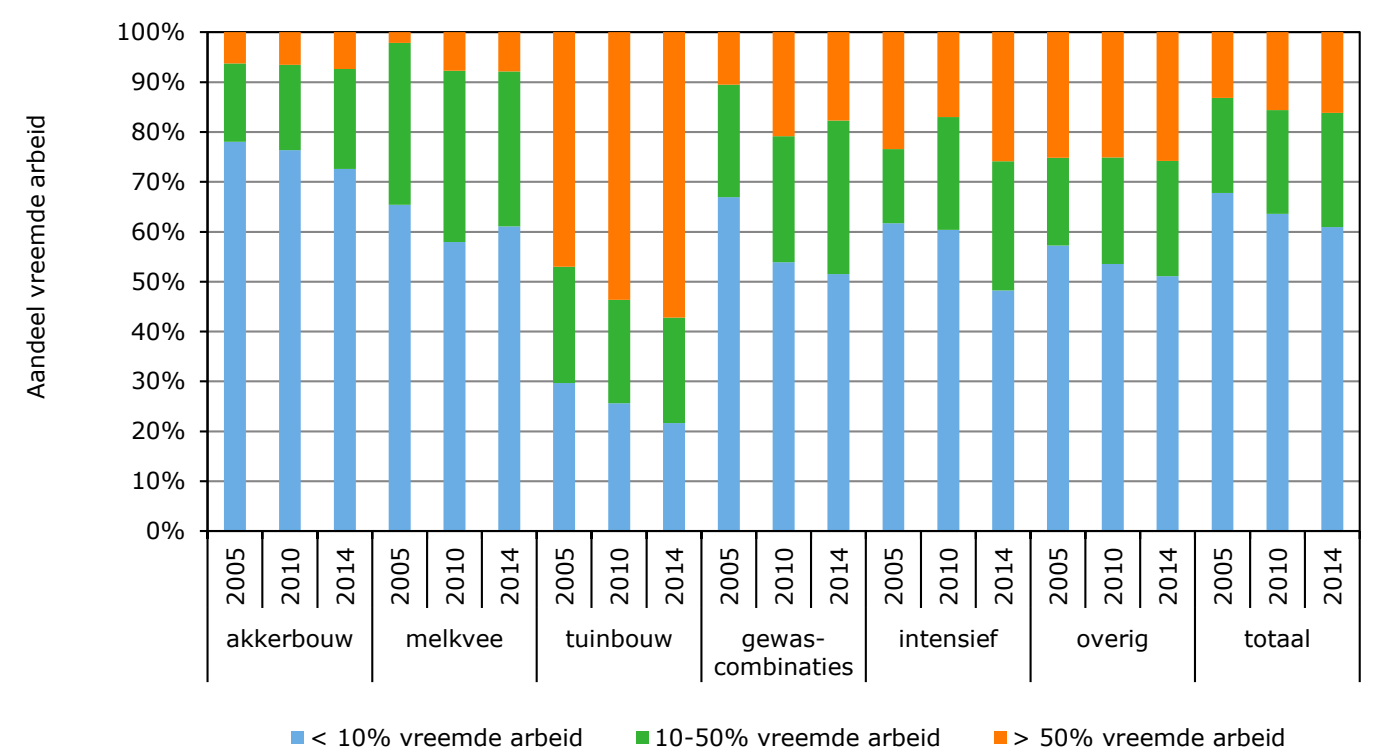

Figuur 2.17 Landbouw- en tuinbouwbedrijven in Flevoland naar aandeel vreemde arbeid en bedrijfstype in 2005, 2010 en 2014

Gemiddeld werd in 2014 op $61 \%$ van de Flevolandse bedrijven vrijwel alle arbeid door het gezin geleverd (categorie 1), 23\% van de bedrijven viel in categorie 2 en op 16\% van de bedrijven was de vreemde arbeid in de meerderheid (Figuur 2.17). De afgelopen 10 jaar is het aantal bedrijven met veel vreemde arbeid langzaam toegenomen.

Er zijn wat dit betreft duidelijke verschillen tussen bedrijfstypen. Op akkerbouw- en melkveebedrijven is op minder dan $10 \%$ van de bedrijven de vreemde arbeid in de meerderheid. Op de andere bedrijfstypen is dat duidelijk meer. Ongeveer $50 \%$ van de tuinbouwbedrijven werkt met een meerderheid aan vreemde arbeid. Op de andere bedrijfstypen ligt dit percentage op ongeveer $20 \%$ (Figuur 2.17).

Naast arbeid kunnen we ook naar de factor kapitaal kijken. Als indicator daarvoor is de juridische rechtsvorm van de bedrijven genomen (zie Figuur 2.18). Uit de tabel blijkt dat het percentage bedrijven op naam van een rechtspersoon (Naamloze en Besloten Vennootschappen, coöperaties, verenigingen en stichtingen ${ }^{8}$ ) in Flevoland slechts iets lager is dan op nationaal niveau. Het aandeel rechtspersonen op melkveebedrijven neemt wel snel toe en is ook hoger dan op de melkveebedrijven in Noord-Nederland.

Op de akkerbouwbedrijven is er een veel geringere stijging in vergelijking met andere akkerbouwgebieden en ligt het niveau in 2014 gemiddeld iets onder die van de andere akkerbouwgebieden. Het aandeel rechtspersonen moet op de niet-akkerbouw- en niet-melkveebedrijven in Flevoland hoger liggen dan op deze genoemde grondgebonden typen omdat het gemiddelde van geheel Flevoland boven deze twee typen ligt.

\footnotetext{
8 Man-vrouw- en ouder-kindmaatschappen vallen hier niet onder, evenals de vof's.
} 




Figuur 2.18 Percentage bedrijven met rechtspersoonlijkheid in 2005, 2010 en 2014

\section{$2.9 \quad$ Verbreding}

De trend in Flevoland op het gebied van verbreding (het aantal bedrijven in Flevoland met verbrede landbouwactiviteiten) is weergegeven in Figuur 2.19. Het CBS onderscheidt als verbredingsactiviteiten: energieproductie, loonwerk voor derden, stalling van goederen of dieren, boerderijeducatie, agrarische kinderopvang, agrotoerisme/recreatie, agrarisch natuur- en landschapsbeheer, verwerking van landbouwproducten en verkoop aan huis en zorglandbouw. In Flevoland komt volgens het CBS relatief meer verbreding voor dan gemiddeld in Nederland. ${ }^{9}$

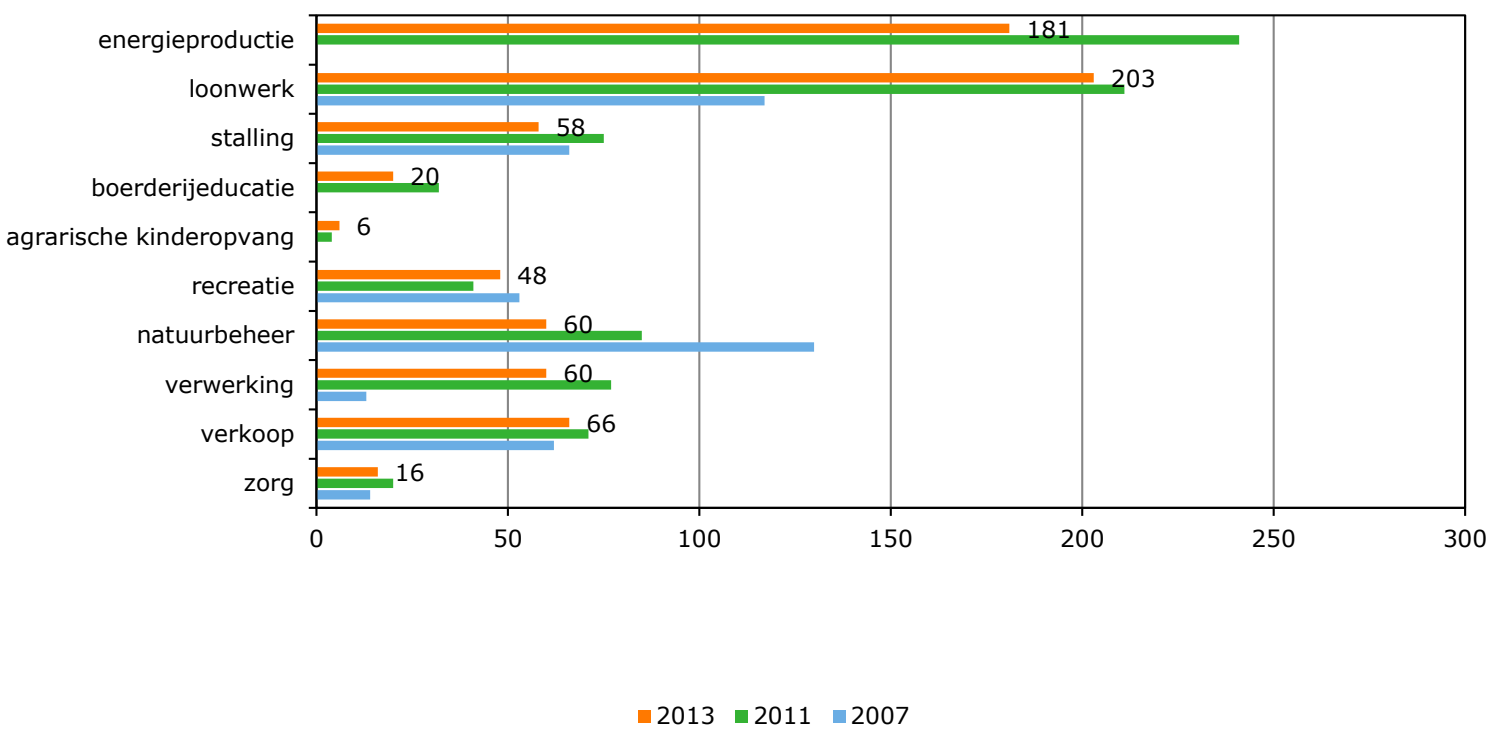

Figuur 2.19 Aantal bedrijven naar soort verbreding in Flevoland in 2007, 2011 en 2013 Bron: Landbouwtelling.

\footnotetext{
9 Deze constatering heeft te maken met de hier gebruikte definitie van verbreding. In dit geval omvat deze namelijk ook energieproductie en loonwerk voor derden. Als een wat 'smallere' definitie zonder deze activiteiten wordt gehanteerd, dus wat meer gericht op directe dienstverlening aan burgers, dan is het beeld minder gunstig.
} 
In 2013 was het aantal verbredingsactiviteiten op landbouwbedrijven in Flevoland gemiddeld 0,4. De opbrengst van deze activiteiten bleef in $60 \%$ van de gevallen beperkt tot minder dan $10 \%$ van de totale bedrijfsomzet. In $5 \%$ van de gevallen was de opbrengst uit verbreding meer dan $50 \%$ van de totale omzet (Bron: CBS-Landbouwtelling). Hieronder worden de verschillende verbredingsactiviteiten nader toegelicht.

De bijdrage van verbredingsactiviteiten aan het inkomen van agrariërs is niet op provincieniveau bekend. Wel zijn nationale cijfers bekend (www.wageningenur.nl/nl/nieuws/Omzet-multifunctionelelandbouw-opnieuw-gestegen.htm). De omzet in de multifunctionele landbouw in Nederland is tussen 2011 en 2013 met $€ 14 \mathrm{mln}$. toegenomen tot $€ 491 \mathrm{mln}$. Zorglandbouw en boerderijwinkels zien hun omzet tussen 2011 en 2013 met 20\% stijgen en de agrarische kinderopvang zelfs met 30\%. In totaal zijn er in Nederland 12.800 multifunctionele bedrijven, waarvan sommigen activiteiten hebben in meerdere sectoren. Recreatie is met $€ 151 \mathrm{mln}$. de grootste sector, gevolgd door verkoop van producten op de boerderij met $€ 142 \mathrm{mln}$. Daarna volgen zorglandbouw ( $€ 95 \mathrm{mln}$.) en natuurbeheer ( $€ 75 \mathrm{mln}$.). Kinderopvang ( $€ 26 \mathrm{mln}$.) en educatie ( $€ 2 \mathrm{mln}$.) laten als sector de minste omzet zien. Opvallend is de omzetgroei van de agrarische kinderopvang in een krimpende markt. Agrarische kinderopvang weet zich door een groen imago te onderscheiden van reguliere kinderopvang. De omzet in de recreatie staat onder druk.

\section{Energieproductie}

Energieproductie voor eigen gebruik wordt, conform de EU-richtlijn, niet als verbreding beschouwd, maar als efficiency- of kostenbesparingsmaatregel. Ook de teelt van energiegewassen en de verhuur van grond om er windmolens op te plaatsen wordt niet tot verbrede landbouw gerekend. Wat betreft energieopwekking op agrarische bedrijven staat Flevoland boven aan de scorelijst. Volgens de CBSLandbouwtelling wekken bijna 200 (10\%) agrarische bedrijven energie op als neventak. Landelijk gezien komt energieopwekking slechts voor op nog geen $2 \%$ van de landbouwbedrijven. De daling van het Flevolandse aantal in 2013 heeft waarschijnlijk te maken met een nauwere definitie van energieproductie.

\section{Loonwerk voor derden}

De investeringen en de bijbehorende kosten voor machines en werktuigen op landbouwbedrijven, en in het bijzonder akkerbouwbedrijven, zijn over het algemeen hoog. Voor een aantal landbouwers is dit reden om te proberen hun machinepark beter te benutten door werk voor derden uit te voeren. In Flevoland gebeurt dit meer dan in andere regio's. Ongeveer 200 Flevolandse bedrijven (11\%) geeft aan werkzaamheden voor anderen uit te voeren; landelijk gezien ligt dit percentage op 6\%.

\section{Stalling}

Een kleine zestig bedrijven in Flevoland biedt stalling aan voor caravans, andere goederen of vee. Dat is relatief gezien iets minder dan het landelijk gemiddelde.

\section{Boerderijeducatie}

Twintig bedrijven in Flevoland bieden educatie aan op hun bedrijf. Dit komt verhoudingsgewijs overeen met het Nederlands gemiddelde. Van der Meulen (2014) schat dat een kwart van de bedrijven (nationaal gezien) hier professioneel mee bezig zijn. Zij ontvangen meer dan dertig groepen per jaar en genereren daarmee een jaarlijkse omzet van 4.000 tot 7.500 euro. Vanwege bezuinigingen op schoolbudgetten staat de omzet echter onder druk.

\section{Agrarische kinderopvang}

Slechts een handjevol bedrijven in Flevoland vangt kinderen op. De omvang daarvan varieert van gastouderschap tot professionele opvang in groepen met hulp van personeel.

\section{Agrotoerisme/recreatie}

Bij recreatie op de boerderij gaat het zowel om dagrecreatie als verblijfsrecreatie. In Flevoland gaat het om ongeveer vijftig bedrijven, duidelijk minder dan in de meeste andere regio's. Van der Meulen (2014) geeft aan dat aanbieders van agrotoerisme daarmee gemiddeld ongeveer 50.000 euro aan omzet behalen, afhankelijk van de omvang en het soort activiteit. 


\section{Natuur- en landschapsbeheer}

Agrarisch natuurbeheer betekent dat ondernemers natuur op eigen of pachtgrond onderhouden, zoals een houtwal of een bloemrijke akkerrand. Agrariërs kunnen hiervoor subsidie ontvangen ter compensatie van derving aan agrarische inkomsten. Een deel van de subsidies loopt via de Provinciale Subsidieregeling Agrarisch Natuurbeheer (PSAN) en Provinciale Subsidieregeling Natuur (PSN), een ander deel is afkomstig van de sinds 1 januari 2010 lopende Subsidieregeling Natuur- en Landschapsbeheer (SNL).

Het is de bedoeling dat vanaf 2016 het agrarisch natuurbeheer via collectieven wordt georganiseerd op plekken die het meest kansrijk zijn voor een goed natuurrendement. Boeren sluiten daarbij niet langer een beheercontract met de overheid, maar met een (agrarisch) collectief dat kan bestaan uit agrariërs en andere landgebruikers. In Flevoland is de oprichting van één collectief voor de hele provincie in voorbereiding. Ongeveer 60 grondgebonden boerenbedrijven in de provincie doen mee aan agrarisch natuurbeheer. Dat is verhoudingsgewijs weinig: landelijk is het percentage landbouwbedrijven met natuurbeheer driemaal zo groot.

\section{Verwerking van boerderijproducten}

Onder verwerking van boerderijproducten wordt verstaan het geven van toegevoegde waarde aan het onbewerkte landbouwproduct. In feite betreft het een vorm van ketenverkorting, ${ }^{10}$ waarbij de verwerking plaatsvindt op de boerderij in plaats van in de volgende schakel(s) van de keten. Een bekend voorbeeld in de veehouderij is het maken van kaas op basis van de zelfgeproduceerde melk; op akker- en tuinbouwbedrijven gaat het om het verwerken van bijvoorbeeld aardbeien tot jam, fruit tot sap of het drogen van streekgebonden peulvruchten. In Flevoland houden circa 60 bedrijven zich met deze activiteiten bezig. Procentueel is dit ongeveer tweemaal zo veel als gemiddeld in Nederland. De omvang van de verwerkingstak kan tussen bedrijven enorm verschillen. Vaak worden de producten verwerkt door de landbouwer en zijn gezinsleden, maar soms groeit de verwerking uit en wordt speciaal hiervoor betaald ('vreemd') personeel aangetrokken.

\section{Boerderijverkoop}

Met boerderijverkoop wordt de directe afzet van een boer aan consumenten, catering, instellingen en horeca verstaan. Leveringen via een tussenschakel (ook wel korte keten genoemd), bijvoorbeeld levering aan (web)winkels of pakket- en abonnementsdiensten, vallen hier buiten.

Volgens de CBS-Landbouwtelling gaven in 201366 bedrijven in Flevoland aan producten aan huis te verkopen. Het aantal boerderijverkopers is in Flevoland met 3,7\% relatief iets kleiner dan gemiddeld in Nederland (4,5\%). Dat geldt ook voor het aantal boerderijverkopers per 100.000 inwoners. In Flevoland ligt dat aantal op 16,5 tegenover 18,0 in Nederland.

De omzet op bedrijven met boerderijverkoop is gemiddeld ruim 5.000 euro per bedrijf (Van der Meulen, 2014) De totale geldomzet die door directe afzet van landbouwproducten in Flevoland wordt gegenereerd wordt door Van der Meulen et al. geschat op circa 350.000 euro.

\section{Zorglandbouw}

In 2013 telde Flevoland 16 zorgboerderijen. Zij bieden hulp aan personen met een zorgvraag. Dit kunnen bijvoorbeeld mensen zijn met verstandelijke of lichamelijke beperkingen, langdurig werklozen, personen met een psychische hulpvraag, (ex)gedetineerden, (ex)verslaafden, asielzoekers, maar ook de opvang van kinderen en ouderen 'met een rugzakje' kan hieronder vallen. Zowel in verhouding tot de Flevolandse bevolking als tot het aantal landbouwbedrijven is dit aantal zorgboerderijen iets kleiner dan het landelijk gemiddelde. Landelijk is het aantal zorgboerderijen de afgelopen jaren toegenomen, maar in Flevoland zien we een lichte teruggang in het aantal bedrijven met zorglandbouw. Landelijk gezien beschikte tweederde deel van deze bedrijven over een gecertificeerd kwaliteitssysteem.

\footnotetext{
${ }^{10}$ De Agenda Vitaal Platteland van de Provincie Flevoland noemt deze werkwijze 'ketenverlenging', een term die betrekking heeft op het aantal schakels op het agrarische bedrijf. Vanuit de gehele keten gedacht is de term 'ketenverkorting' op zijn plaats.
} 


\subsection{Grondposities en verkavelingssituatie}

De situatie met betrekking tot eigendom en pacht van de grond in de akkerbouwsector, de zogenoemde grondposities' in Flevoland is weergegeven in Figuur 2.20. Hieruit blijkt dat op de akkerbouwbedrijven in Flevoland het aandeel grond in eigendom tussen 2010 en 2014 licht is toegenomen tot $43 \%$ ten koste van met name het aandeel pacht (in $201452 \%$ ).

Uit Figuur 2.21 blijkt dat op de melkveebedrijven in Flevoland het aandeel grond in eigendom licht is toegenomen tussen 2005 en 2010 ten koste van het areaal erfpacht maar daarna nauwelijks meer aan verandering onderhevig is geweest.



" eigendom -erfpacht pacht

Figuur 2.20 Arealen grond in eigendom, erfpacht of pacht in 2005, 2010 en 2014 op akkerbouwbedrijven in Flevoland



Figuur 2.21 Arealen grond in eigendom, erfpacht of pacht in 2005, 2010 en 2014 op melkveebedrijven in Flevoland

Bron: Kadaster. 
De grondprijs in Flevoland ligt hoger dan gemiddeld in Nederland. Het absolute en relatieve verschil tussen die twee nam tussen 2005 en 2010 fors is toe, maar is tussen 2010 en 2014 weer afgenomen (Figuur 2.22). Gemiddeld was het verschil in 2014 evenwel nog steeds $€ 20.000$ per hectare.

In het project 'Verkavelen voor groei' is in 2014 naar de verkavelingsstructuur van Flevoland gekeken, in dit geval onderverdeeld naar NOP en Oostelijk en Zuidelijk Flevoland (DLG, 2014). De uitkomsten daarvan staan in Tabel 2.8. Gemiddeld is in beide deelgebieden de helft tot twee derde van de kavels een huiskavel. Het merendeel van die kavels, ongeveer $60 \%$, heeft in de NOP een omvang van 25-41 ha en in Oostelijk en Zuidelijk Flevoland van 31-51 ha. Een derde van de huiskavels in de NOP is 24 ha groot. Het aantal veldkavels versterkt onderling sterk, maar gemiddeld heeft men in beide gebieden 1 à 1,5 veldkavel per bedrijf. In de NOP zijn die kavels bijna altijd tussen 6 en 22 ha groot; ongeveer $15 \%$ zit in de categorie 22-36 ha. In Oostelijk en Zuidelijk Flevoland is twee derde van de veldkavels tussen 9 en 30 ha groot, maar ongeveer $20 \%$ is kleiner dan 9 ha en een even groot percentage groter dan 30 ha.

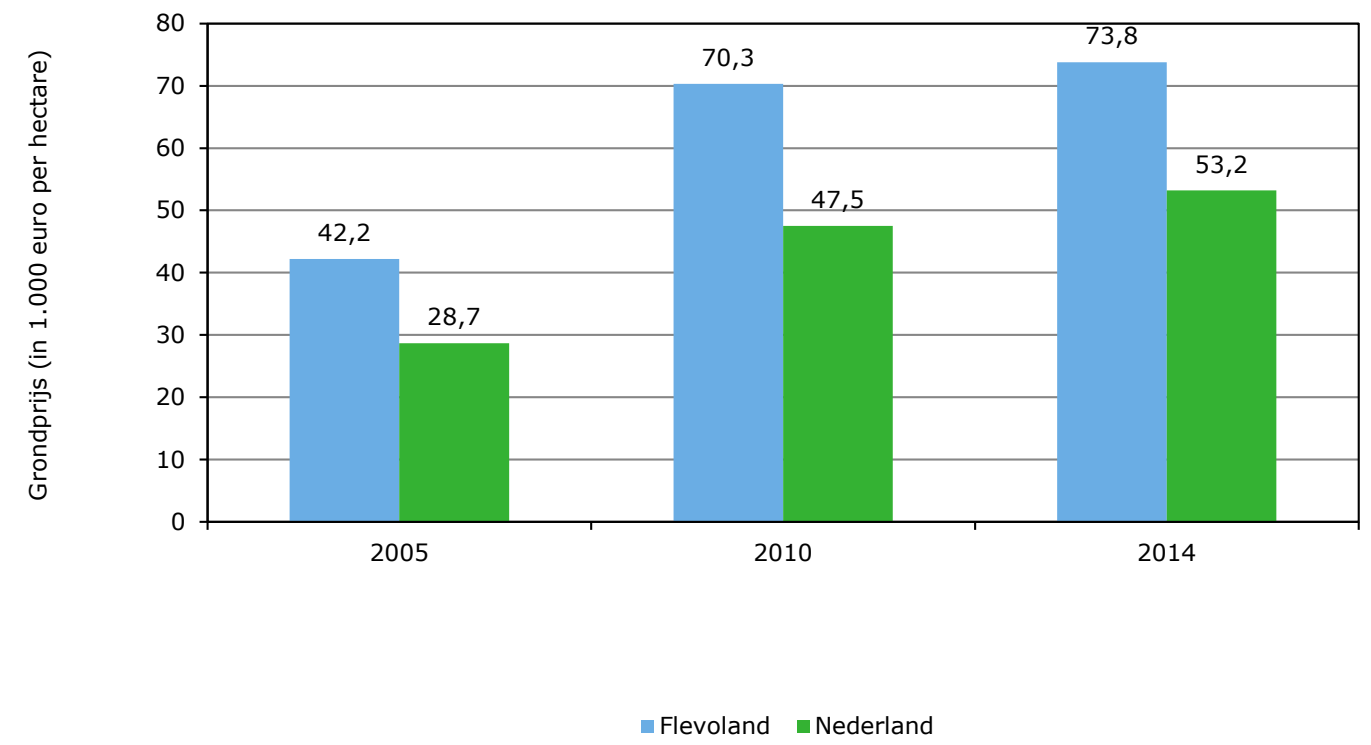

Figuur 2.22 Grondprijs (in 1.000 euro per hectare) in Flevoland versus Nederland in 2005, 2010 en 2014 (gemiddelden van bouw- en grasland)

Bron: Kadaster. 
Tabel 2.8

Verkavelingssituatie in Flevoland in 2014

\begin{tabular}{|c|c|c|c|}
\hline \multirow{2}{*}{\multicolumn{2}{|c|}{ Variabele }} & \multicolumn{2}{|c|}{ Situatie voor deelgebied } \\
\hline & & NOP & Oostelijk en Zuidelijk Flevolanc \\
\hline \multicolumn{2}{|c|}{ Percentage huiskavels (\%) a) } & $50-66$ & $50-66$ \\
\hline$>72$ ha & >90 ha & 0 & 0 \\
\hline $56-72$ ha & $71-90$ ha & 5 & 0 \\
\hline $25-41$ ha & $31-51$ ha & 60 & 75 \\
\hline 24 ha & $<31$ ha & 30 & 10 \\
\hline \multicolumn{2}{|c|}{ Aantal veldkavels per bedrijf a) } & $1-1,5$ & $1-1,5$ \\
\hline \multicolumn{4}{|c|}{ Gemiddelde veldkavelgrootte } \\
\hline $6-12$ ha & $9-18$ ha & 45 & 30 \\
\hline$<6$ ha & $<9$ ha & 0 & 20 \\
\hline \multicolumn{4}{|c|}{ Kwaliteit verkaveling b) } \\
\hline \multicolumn{2}{|l|}{ Uitstekend } & 0 & 5 \\
\hline \multicolumn{2}{|l|}{ Goed } & 0 & 15 \\
\hline \multicolumn{2}{|l|}{ Redelijk } & 20 & 20 \\
\hline \multicolumn{2}{|l|}{ Matig } & 40 & 35 \\
\hline \multicolumn{2}{|l|}{ Slecht } & 40 & 25 \\
\hline
\end{tabular}

a) Meest voorkomende categorie.

b) Over het landbouwareaal, per gebied; eerste indeling geldt voor NOP, tweede voor Oostelijk en Zuidelijk Flevoland.

Bron: Project 'Verkavelen voor groei' van Dienst Landelijk Gebied, 2014.

Het totaaloordeel over de verkavelingssituatie is dat in de NOP $80 \%$ van het areaal in de categorieën 'slecht' of 'matig' valt en de overige $20 \%$ in 'redelijk'. In Oost- en Zuid-Flevoland ligt die verdeling wel wat gunstiger, maar ook daar valt ongeveer twee derde van het areaal in de categorieën 'slecht' of 'matig'. Slechts $20 \%$ van het areaal valt in de categorieën 'goed' of 'uitstekend'. Op het eerste gezicht ligt hier dus zeker een aandachtspunt.

\subsection{Biologische landbouw}

Het belang van de biologische landbouw in Flevoland is weergegeven in Figuur 2.23, uitgedrukt in het aantal bedrijven. Deze sector is relatief gezien erg belangrijk in Flevoland. Was het aandeel biologisch bedrijven landelijk gezien in 2014 ruim 2\%, in Flevoland was dat aandeel in dat jaar bijna $9 \%$. Uit de figuur blijkt dat hogere aandeel zowel voor de akkerbouw als de melkveehouderij te gelden.

Bovendien neemt dat aandeel in beide sectoren relatief snel toe. Dat wil overigens niet zeggen dat ook het productieaandeel even hoog is als het aandeel bedrijven. De fysieke productie op biologische bedrijven is gemiddeld genomen kleiner dan op gangbare. Dat komt enerzijds omdat de bedrijfsomvang vaak wat kleiner is en anderzijds vanwege de lagere opbrengsten per ha en per koe. Daar tegenover staan vaak hogere opbrengstprijzen voor de producten. 


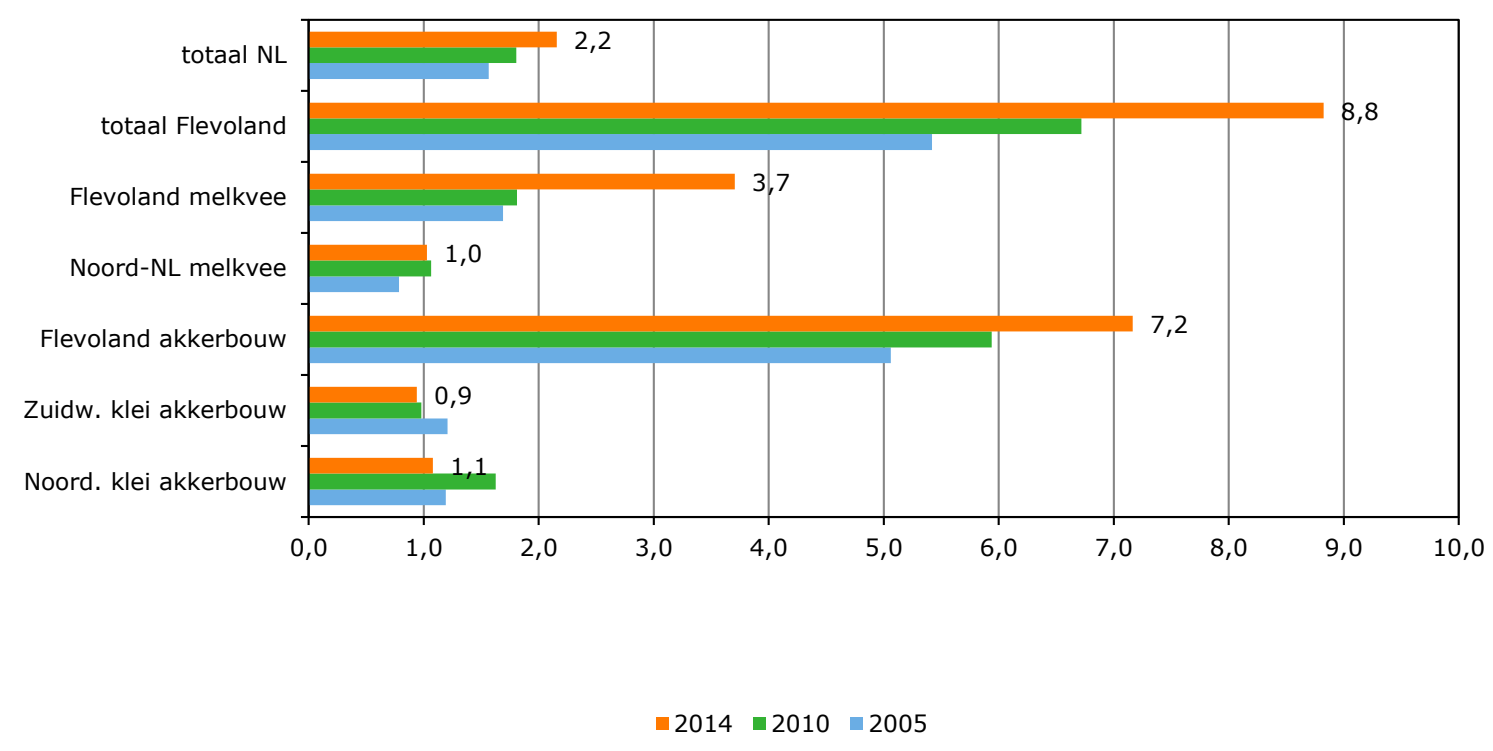

Figuur 2.23 Aandeel biologische bedrijven in \% naar bedrijfstype en regio in 2005, 2010 en 2014 Bron: CBS-Landbouwtelling.

De absolute aantallen biologische bedrijven in Flevoland zijn opgenomen in Bijlage 3 van dit rapport. Het totaal aantal biologische bedrijven in Nederland is sinds 2005 toegenomen van een kleine 1.300 naar ruim 1.400, ofwel met 10\%. In Flevoland steeg het aantal in diezelfde periode van 115 naar 156 bedrijven, ofwel met maar liefst 36\%. Die toename is niet in de eerste plaats opgetreden in de akkerbouw en de melkveehouderij in Flevoland, want er kwamen in die tien jaar 'maar' acht biologische akkerbouw- en vier biologische melkveebedrijven in Flevoland bij. Voor de akkerbouw is dat nog relatief gunstig; in de twee andere akkerbouwgebieden is het aantal biologische bedrijven sinds 2005 juist gedaald. De toename ligt vooral bij de vollegrondsgroententeelten.

\subsection{Opbrengend vermogen van de grond}

In de Figuren 2.24 en 2.25 staan de kg-opbrengsten voor rooigewassen en granen in twee periodes, 2000-2004 en 2010-2014. In verband met schommelingen in kg-opbrengsten vanwege verschillen in groeiomstandigheden per jaar zijn vijf-jaarlijkse gemiddelden voor beide perioden gegeven. 


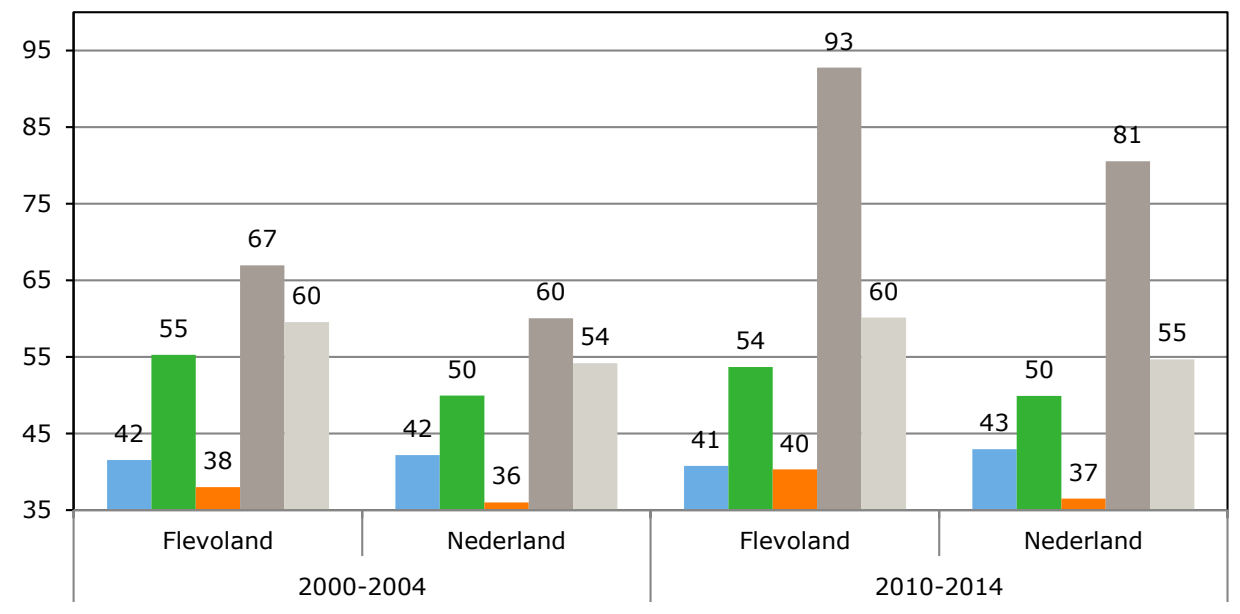

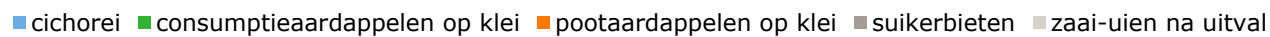

Figuur 2.24 Kg-opbrengsten rooigewassen (x 1.000 kg) in 2000-2004 en 2010-2014 voor Flevoland en Nederland.

Bron: CBS-Oogstraming.

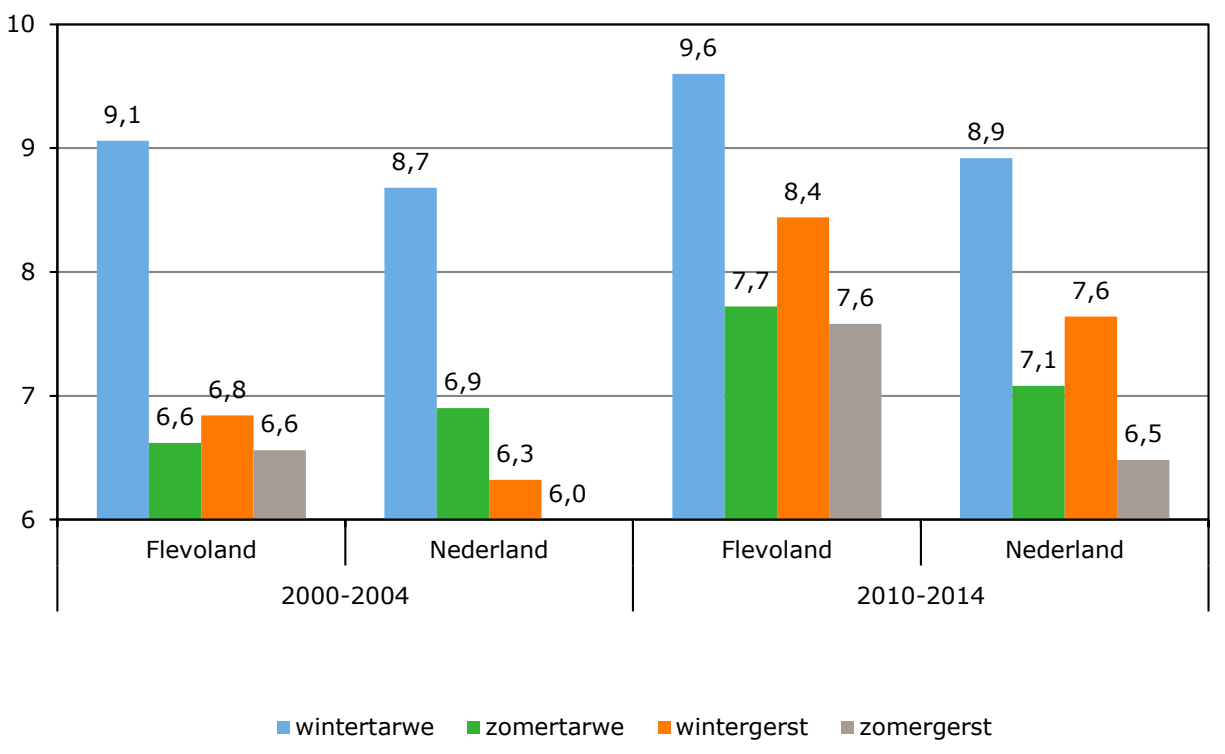

Figuur $2.25 \mathrm{Kg}$-opbrengsten granen (x 1.000 kg) in 2000-2004 en 2010-2014 voor Flevoland en Nederland.

Bron: CBS Oogstraming.

De meeste gewassen hebben in Flevoland een gemiddelde 10-15\% hogere kg-opbrengst dan gemiddeld over heel Nederland, zowel in de eerste als in de tweede periode; cichorei is echter een uitzondering op dit algemene beeld. De meeste $\mathrm{kg}$-opbrengsten zijn in deze periode ook toegenomen en meestal sterker in Flevoland dan in Nederland als geheel. Voor consumptieaardappel en cichorei zijn de opbrengsten in Flevoland evenwel afgenomen. Deze ontwikkeling is bij consumptieaardappelen op klei voor geheel Nederland vrijwel nul. Figuur 2.26 vat deze analyse samen per gewas. 


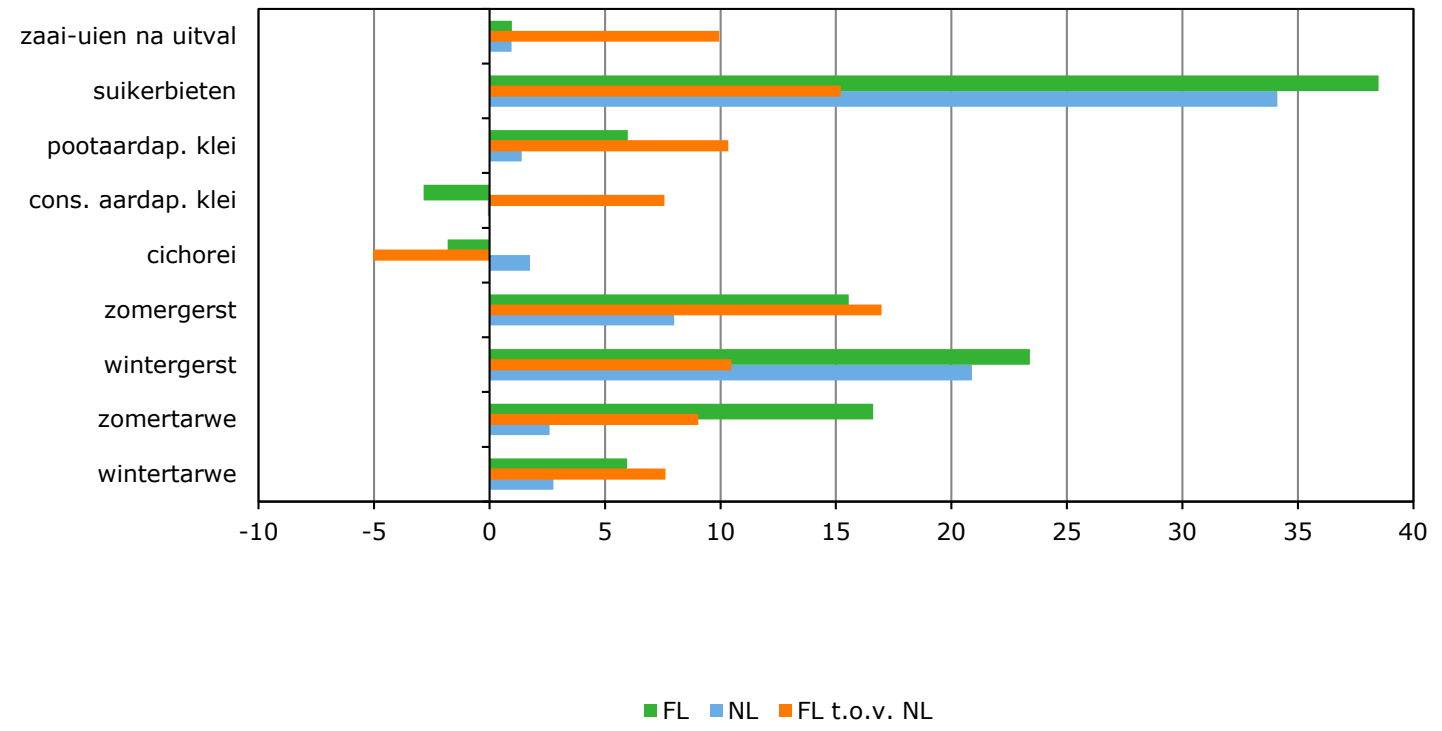

Figuur 2.26 Ontwikkeling kg-opbrengsten 2010-2014 ten opzichte van 2000-2004 in Flevoland en Nederland als geheel Bron: CBS Oogstraming.

\subsection{Inkomensontwikkeling en saldi in de land- en tuinbouwsectoren}

\section{Melkveehouderij}

Omdat in het Bedrijveninformatienet van het LEI onvoldoende melkveebedrijven aanwezig zijn in Flevoland om gefundeerde uitspraken te kunnen doen over de inkomensontwikkeling in de sector in de provincie als totaal, worden de grotere melkveebedrijven uit Groningen en Friesland in deze analyse meegenomen als zijnde representatief voor de melkveehouderij in Flevoland. De resultaten van deze groep worden vergeleken met vergelijkbare bedrijven elders in Nederland en met alle melkveebedrijven in Nederland. Hierbij zijn de grotere melkveebedrijven gedefinieerd als 'meer dan 75 koeien'. Om schommelingen uit te sluiten heeft de vergelijking betrekking op een 5 -jarige periode (2009-2013) (Tabel 2.9). 
Tabel 2.9

Resultaten en saldi in Flevoland a) met melkvee NL totaal (5 jaarlijkse gemiddelden 2009-2013)

\begin{tabular}{|c|c|c|c|}
\hline Variabele & $\begin{array}{l}\text { Flevoland } \\
\text { melkvee en } \\
\text { Noord-NL } \\
>75 \text { koeien }\end{array}$ & $\begin{array}{l}\text { Melkvee } \\
\text { Nederland } \\
>75 \text { koeien }\end{array}$ & $\begin{array}{l}\text { Melkvee } \\
\text { Nederland }\end{array}$ \\
\hline Aantal steekproefbedrijven & 49 & 167 & 291 \\
\hline Standaard opbrengsten ( $x 1.000$ euro) & 436 & 409 & 282 \\
\hline Opbrengsten per koe (euro per jaar) & 3.856 & 3.919 & 3.921 \\
\hline Betaalde kosten en afschrijving per koe (euro per jaar) & 3.409 & 3.470 & 3.456 \\
\hline Aantal melkkoeien c) & 132 & 123 & 84 \\
\hline Melkproductie per koe $(\mathrm{kg})$ & 7.988 & 8.130 & 8.064 \\
\hline
\end{tabular}

a) Flevoland inclusief grotere bedrijven in het Noordelijk weidegebied ( $>75$ koeien) in verband met het kleine aantal steekproefbedrijven in Flevoland zelf.

b) Aje = Arbeidsjaareenheid; 'onbetaalde aje's' worden ingevuld door de ondernemer met eventueel meewerkende gezinsleden.

c) Dit is het gemiddelde gewogen aantal koeien c.q. areaal op de steekproefbedrijven in het Bedrijveninformatienet; deze data kunnen afwijken van de gegevens uit de Landbouwtelling.

Bron: Bedrijveninformatienet van het LEI.

Uit deze tabel blijkt dat er weinig verschil is in resultaten tussen de grotere melkveebedrijven in Flevoland en die in Nederland als geheel, al hebben deze bedrijven in Flevoland gemiddeld een groter aantal koeien en een grotere bedrijfsoppervlakte. Dit betreft zowel het inkomen uit bedrijf, de kg- en financiële opbrengsten, als de kosten en het saldo per koe. Doordat beide groepen bedrijven een veel grotere omvang hebben dan het landelijke gemiddelde zijn er wel verschillen met deze groep. Dit betreft niet zozeer de kengetallen per koe maar wel het inkomen uit bedrijf en de kostprijs per kg melk, die over het algemeen genomen sterk omvang gerelateerd zijn.

\section{Akkerbouw}

Er zijn voldoende akkerbouwbedrijven in het Bedrijveninformatienet van het LEI in de provincie Flevoland om een representatief beeld te kunnen geven. Deze groep wordt hieronder vergeleken met de akkerbouwbedrijven uit het Noordelijk en het Zuidwestelijk kleigebied (gemiddeld 2009-2013) (Tabel 2.10). 
Tabel 2.10

Resultaten en saldi in Flevoland en enkele vergelijkbare akkerbouwgebieden (5-jaarlijkse (gewogen) gemiddelden 2009-2013)

\begin{tabular}{|c|c|c|c|}
\hline Variabele & $\begin{array}{l}\text { Flevoland } \\
\text { akkerbouw }\end{array}$ & $\begin{array}{l}\text { Noordelijk } \\
\text { kleigebied }\end{array}$ & $\begin{array}{l}\text { Zuidwestelijk } \\
\text { kleigebied }\end{array}$ \\
\hline Aantal steekproefbedrijven & 27 & 42 & 49 \\
\hline Standaard opbrengsten (x 1.000 euro) & 263 & 191 & 189 \\
\hline Inkomen uit bedrijf per onbetaalde aje (euro) a) & 76.359 & 77.892 & 65.219 \\
\hline Opbrengsten per hectare (euro) & 8.351 & 4.489 & 4.323 \\
\hline Betaalde kosten en afschrijving per hectare (euro) & 6.552 & 3.348 & 3.294 \\
\hline Betaalde rente per hectare (euro) & 811 & 312 & 267 \\
\hline Betaalde pacht per hectare (euro) & 703 & 187 & 313 \\
\hline Afschrijving en onderhoud per hectare (euro) & 1.609 & 1.031 & 777 \\
\hline Algemene kosten per hectare (euro) & 333 & 251 & 249 \\
\hline Werk door derden per hectare (euro) & 287 & 146 & 258 \\
\hline Betaalde arbeid per hectare (euro) & 331 & 189 & 62 \\
\hline Energie en brandstoffen per hectare (euro) & 437 & 256 & 219 \\
\hline Toegerekende kosten per hectare (euro) & 1.871 & 844 & 1.037 \\
\hline Oppervlakte cultuurgrond (ha) b) & 55 & 76 & 69 \\
\hline Saldo tarwe per hectare (euro) c) & 1.430 & 1.456 & 1.243 \\
\hline Saldo pootaardappelen per hectare (euro) c) & 8.118 & 7.228 & 5.681 \\
\hline Saldo consumptieaardappelen per hectare (euro) c) & 6.433 & 4.459 & 4.470 \\
\hline Saldo suikerbieten per hectare (euro) c) & 4.359 & 3.282 & 3.520 \\
\hline Saldo zaaiuien per hectare (euro) c) & 6.289 & 4.978 & 4.645 \\
\hline
\end{tabular}

a) Aje = Arbeidsjaareenheid; 'onbetaalde aje's' worden ingevuld door de ondernemer met eventueel meewerkende gezinsleden.

b) Dit is het gemiddelde gewogen areaal op de steekproefbedrijven in het Bedrijveninformatienet; dat kan afwijken van de gegevens uit de Landbouwtelling.

c) Na aftrek van de kosten voor werk door derden (loonwerk).

Bron: Bedrijveninformatienet van het LEI.

Bij deze vergelijking valt op dat de gemiddelde geldopbrengsten per hectare in Flevoland fors hoger liggen dan gemiddeld in Nederland. Dit hangt samen met het intensievere bouwplan. Bovendien scoren aardappelen, bieten en uien qua saldo in Flevoland beter dan in de andere twee kleigebieden met akkerbouw (circa 1.000 tot 2.000 euro per hectare hoger). Ondanks de hogere opbrengsten en saldi is het inkomen uit bedrijf per arbeidseenheid niet hoger. Dit komt doordat met name de vaste kosten circa 2.000 euro per hectare hoger zijn; deze maken ongeveer $60 \%$ van de totale kosten per ha uit (naast $40 \%$ toegerekende kosten). In Tabel 2.10 gaat het om de posten rente, pacht, afschrijving en onderhoud, algemene kosten, werk door derden en betaalde arbeid. Opvallend zijn in dit verband de hoge bedragen aan betaalde rente, pacht, afschrijving en onderhoud. De gewassaldi zijn in Flevoland dus hoger dan elders maar het effect hiervan wordt ongedaan gemaakt door hogere kosten van de grond en de gebouwen inclusief de bewaring van de producten.

Over de inkomensvorming op de akkerbouwbedrijven in Flevoland werd voorheen vanuit de sector wel gesteld dat suikerbieten de kurk van het bedrijf zouden zijn. Maar ook is wel gesteld dat dit tegenwoordig consumptieaardappelen zouden zijn. Deze stelling is onderzocht door het aandeel van suikerbieten en consumptieaardappelen in de totale opbrengsten te onderzoeken. Tabel $2.11 \mathrm{geeft}$ hiervan een overzicht, waaruit blijkt dat de akkerbouw in Flevoland het sterkst afhankelijk is van de opbrengsten van pootaardappelen (in het Noordelijk kleigebied is die afhankelijkheid zelfs nog iets groter). Consumptieaardappelen en uien staan in Flevoland op een gedeelde tweede plaats. Het totaal van de aardappelen is in deze provincie meer dan $40 \%$ van de totale opbrengsten. Dit is meer dan in de beide andere akkerbouwgebieden. De afhankelijkheid van suikerbieten is in Flevoland relatief gering en zelfs nog kleiner dan in de twee andere gebieden. 
Tabel 2.11

Aandeel van verschillende gewassen in de totale opbrengsten op akkerbouwbedrijven in Flevoland en in twee vergelijkingsgebieden

\begin{tabular}{lccc} 
Gewas(sen) & \multicolumn{2}{c}{ Aandeel in totale opbrengsten (\%) op akkerbouwbedrijven in: } \\
\cline { 2 - 4 } Tarwe en gerst & Flevoland & Noordelijk kleigebied & Zuidwestelijk kleigebied \\
\hline Consumptieaardappelen & 16,2 & 21,9 & 14,2 \\
\hline Pootaardappelen & 24,9 & 27,0 & 28,6 \\
\hline Suikerbieten & 7,7 & 10,0 & 5,4 \\
\hline Zaaiui & 15,0 & 3,3 & 11,5 \\
\hline Groenten & 6,2 & 0,9 & 7,9 \\
\hline
\end{tabular}

Bron: CBS-Landbouwtelling en BIN.

\subsection{Gemeenschappelijk Landbouwbeleid}

\section{GLB-toeslagen}

Op dit moment ontvangt ieder landbouwbedrijf bedrijfstoeslagen die gebaseerd zijn op arealen en (met name melk)productie in het verleden. Door veranderingen in het Gemeenschappelijk landbouwbeleid (GLB) van de EU zal er vanaf 2019 sprake zijn van een uniforme hectaretoeslag voor alle bedrijven, ongeacht hun actuele of historische arealen en productie. Deze toeslag zal ongeveer 375 euro per hectare bedragen. Sommige bedrijven, vooral bedrijven met een hoge melkproductie per ha of een groot areaal aan zogenoemde marktordeningsgewassen (granen, peulvruchten, koolzaad, suikerbieten, zetmeelaardappelen), ontvangen nu nog een bedrijfstoeslag per ha die (soms: veel) hoger is dan dat bedrag van $€ 375$ per ha. Zij gaan er door de afgesproken wijzigingen dus in toeslagen en dus in inkomen op achteruit. Andere bedrijven, bijvoorbeeld bedrijven met een relatief lage melkproductie per ha, met extensieve veehouderij zoals schapen en zoogkoeien of een groot aandeel 'vrije', dat wil zeggen niet-marktordeningsgewassen (poot- consumptieaardappelen, groenten en uien) ontvangt nu nog een hectaretoeslag die lager is dan $€ 375$ per ha. Zij zullen vanaf 2019 hogere toeslagen per ha ontvangen en dus in inkomen toenemen.

In Tabel 2.12 is voor de akkerbouw- en melkbedrijven berekend wat de effecten zijn als de huidige bedrijfstoeslag (gemiddeld over de jaren 2009-2013) in 2019 omgezet zal zijn in genoemde hectaretoeslag. Tussen 2015 en 2019 zal de toeslag voor ieder bedrijf in vijf gelijke stappen naar deze uniforme hectaretoeslag toegroeien.

Het effect op het inkomen uit bedrijf per onbetaalde aje is voor de melkveebedrijven in Flevoland gemiddeld negatief (- 8.000 euro). Het gemiddelde bedrijf is qua intensiteit (in melkproductie per ha) vergelijkbaar met het landelijk gemiddelde zodat alleen de omvang van het gemiddelde bedrijf in Flevoland van invloed is op het verschil met het gemiddelde Nederlandse melkveebedrijf. Dit negatieve effect bedraagt circa $14 \%$ van het inkomen per onbetaalde aje. Voor alle grotere melkveebedrijven in Nederland is dit effect groter omdat ze iets intensiever zijn en oorspronkelijk meer melk per hectare produceerden met een navenant hogere toeslag. Dit effect is $-18 \%$. Het landelijke cijfer zit met $-15 \%$ hiertussenin.

Voor de akkerbouwbedrijven in Flevoland is het beeld anders. Doordat de bedrijven in Flevoland over het algemeen meer 'vrije' gewassen telen zoals poot- consumptieaardappelen, groenten en uien ontvingen ze lagere toeslagen per ha. Dit is trouwens in het Zuidwestelijk kleigebied ook het geval. De akkerbouwers in Flevoland gaan er een paar duizend (2.400) euro op vooruit en hun inkomen neemt hierdoor enkele procenten toe. De effecten zijn positief maar gering. In het Noordelijk kleigebied is het effect daarentegen $3 \%$ negatief, omdat de bedrijven in dat gebied(meer granen en bieten telen, met een toeslag boven de uniforme hectare toeslag). In het Zuidwestelijk kleigebied is het inkomenseffect $+4 \%$. Het absolute inkomenseffect ligt daar met $€ 3.200$ licht hoger dan in Flevoland door het (eveneens) grote aandeel vrije gewassen en de grotere oppervlakte dan in Flevoland. 
De landbouw in Flevoland ontvangt overigens circa 30 miljoen (cijfer 2012); dat is bijna 4\% van het totaal uitgekeerde bedrag in Nederland (Bron: RVO bronbestand met betalingen 2012).

Tabel 2.12

Effect GLB op inkomenstoeslagen in 2019 (bij uniforme toeslag van 375 euro per hectare) in 1.000 euro per bedrijf, ten opzichte van de jaren 2009-2013.

\begin{tabular}{|c|c|c|c|}
\hline Melkveebedrijven & $\begin{array}{l}\text { Flevoland melkvee } \\
\text { en Noord-NL } \\
>75 \text { koeien }\end{array}$ & $\begin{array}{l}\text { melkvee } \\
\text { Nederland } \\
>75 \text { koeien }\end{array}$ & $\begin{array}{l}\text { melkvee } \\
\text { Nederland }\end{array}$ \\
\hline Toeslagen 2009-2013 (1.000 euro) & 37,1 & 35,5 & 24,7 \\
\hline Toeslagen 2019 (eindsituatie, 1.000 euro) & 29,1 & 25,5 & 18,6 \\
\hline Akkerbouwbedrijven & $\begin{array}{l}\text { Flevoland } \\
\text { akkerbouw }\end{array}$ & $\begin{array}{l}\text { Noord. klei } \\
\text { akkerbouw }\end{array}$ & $\begin{array}{c}\text { Zuidwest. klei } \\
\text { akkerbouw }\end{array}$ \\
\hline Areaal cultuurgewassen (ha) & 55,2 & 76,0 & 69,0 \\
\hline Toeslagen 2009-2013 (1.000 euro) & 18,3 & 31,4 & 22,7 \\
\hline Toeslagen 2019 (eindsituatie, 1.000 euro) & 20,7 & 28,5 & 25,9 \\
\hline
\end{tabular}

a) Eindsituatie 2019 ten opzichte van het gemiddelde van de jaren 2009-2013.

Bron: Berekening LEI op basis van resultaten uit het Bedrijveninformatienet en met de aanname van een uniforme hectaretoeslag van 375 euro.

\section{Afbouw markt- en prijsbeleid}

Het 'nieuwe' GLB, van toepassing voor de periode 2014-2020, betekent een afbouw van het historische ondersteuningsmodel, dat in feite een overgangsmodel was van hectare- en dierpremies ('Mac Sharry') naar inkomensondersteuning. Ook ontkoppeling van steun aan specifieke (voor Flevoland minder relevante) activiteiten als vleeskalveren, zetmeelaardappelen en vezelgewassen vormt hier een onderdeel van. Europa-breed krijgt de ondersteuning nu dus de vorm van een uniforme hectarepremie met een basis- en een vergroeningsdeel. Na 2020 moet een verdere afbouw van deze premies verwacht worden en een nog sterkere koppeling met maatschappelijke doelen zoals vergroening.

Een ander aspect van de GLB-veranderingen van het afgelopen decennium is een verdere afbouw van het markt- en prijsbeleid. Door afschaffing van zuivel- (2015) en suikerquota (2017) komen de melken suikerprijzen onder druk te staan als gevolg van uitbreiding van de melkveestapel en de suikerbieten-teelt. Naast een lager prijsniveau moet ook een grotere prijsvolatiliteit verwacht worden. Die toenemende prijsschommelingen zullen zich in veel land- en tuinbouwsectoren voordoen, namelijk bij alle producten waar men sterk op export gericht is. Alleen op kleine nichemarkten (zoals specifieke potplant-soorten) heeft de sector dikwijls een grotere invloed op de prijsvorming en ontkomt men aan de mores van de geliberaliseerde wereldmarkt. Vooral in de melkveehouderij is dit een nieuwe ontwikkeling; in de Flevolandse akkerbouw met grote arealen consumptieaardappelen, uien en groenten was men die prijsfluctuaties al gewend.

De combinatie van schaalvergroting, grote investeringen en toenemende prijsvolatiliteit van de producten geeft een grotere financiële kwetsbaarheid op de bedrijven. Daarom is veel aandacht nodig voor risicomanagement. Enerzijds is het zaak het vakmanschap op een hoog peil te houden en hoge productie- en kwaliteitsniveaus te blijven realiseren. Daarbij kunnen extreme weersomstandigheden, ziektes en plagen optreden, waardoor de fysieke, marktwaardige opbrengst sterk kan achterblijven. Anderzijds kunnen prijsfluctuaties de financiële opbrengsten sterk beïnvloeden. Beide soorten risico's vragen actief beleid door de agrariërs en dus van hun ondernemerschap. Te denken valt aan teelttechnische zaken als rassenspreiding, goed niveau van bedrijfshygiëne, goede ontwatering en een beperking van de intensiteit van het bouwplan. Maar ook spreiding van het afzetmoment van producten en eventueel van afzetkanalen kan een middel zijn om de productprijzen op peil te houden. Verkoop van producten via de termijnmarkt kan ook een middel zijn om prijsrisico's te beperken. 


\subsection{Conclusies}

\section{Algemene structuur van de agrarische sector in Flevoland}

In Flevoland is akkerbouw de grootste agrarische sector voor wat betreft het grondgebruik, gevolgd door de (melk)veehouderij (inclusief snijmais), de vollegrondsgroenteteelt en de bloembollenteelt. De bedrijfsomvang is in Flevoland voor alle bedrijfstypen groter dan gemiddeld in Nederland. Op vrijwel alle bedrijfstypen is de bedrijfsomvang de afgelopen tien jaar flink gegroeid. De bedrijfsstructuur is in Flevoland dus gemiddeld gunstig in vergelijking met andere gebieden en er is volop dynamiek in de structuurverbetering.

\section{Structuur van de akkerbouw}

De akkerbouwbedrijven in Flevoland hebben gemiddeld een redelijk intensief bouwplan, intensiever dan gemiddeld in Nederland. Weliswaar worden veelal de 'traditionele' akkerbouwgewassen aardappelen, granen, suikerbiet en uien geteeld, maar het aandeel hakvruchten en groentegewassen is aanmerkelijk hoger dan in andere delen van Nederland, ten koste van het aandeel granen, gras en snijmais. Deze hoge intensiteit vormt een punt van aandacht met het oog op de bodemgezondheid en -kwaliteit. Het aantal akkerbouwbedrijven is de afgelopen jaren in Flevoland sterker gedaald dan in andere akkerbouwgebieden, waardoor de schaalvergroting er ook sneller is gegaan dan gemiddeld in Nederland.

\section{Structuur van de tuinbouw}

Ruim $10 \%$ van de oppervlakte in Flevoland wordt gebruikt voor tuinbouwgewassen, in volgorde: bloembollen, vollegrondsgroenten, fruitteelt (pit-/steenvruchten), boomteelt en een klein areaal kassen. Met name de Noordoostpolder is een erg belangrijk productiegebied voor bloembollen.

\section{Structuur van de melkveehouderij}

Het aantal melkkoeien in Flevoland is de afgelopen tien jaar aanzienlijk gestegen. Tegelijkertijd is het aantal melkveebedrijven in Flevoland diezelfde periode aanzienlijk gedaald, echter minder sterk dan het aantal akkerbouwbedrijven. In Flevoland wordt relatief veel samengewerkt tussen akkerbouw- en melkveebedrijven, tot wederzijds voordeel.

\section{Structuur van de intensieve veehouderij}

Het aantal gespecialiseerde intensieve veebedrijven in Flevoland is de afgelopen tien jaar gestegen van 47 naar 58, waarvan er drie biologisch zijn. Het gaat om een kleine sector met vooral vleesvarkens, leghennen en vleeskuikens. Deze bedrijven zijn groter dan gemiddeld in Nederland, maar door het kleine aantal bedrijven is het aantal 'hokdieren' in Flevoland beperkt.

\section{Aantal bedrijven en schaalgrootte}

De agrarische bedrijven in Flevoland zijn de afgelopen tien jaar flink gegroeid, zowel in areaal of aantal dieren als in zogenoemde 'economisch omvang', dat wil zeggen de capaciteit om omzet te genereren. Alleen de bedrijven met zogenoemde 'graasdieren' (anders dan melkvee, te weten schapen, geiten, zoogkoeien en dergelijke), die vaak een extensief en hobbymatig karakter hebben, zijn in Flevoland gemiddeld gekrompen.

Zowel in de akkerbouw als in de melkveehouderij neemt het aandeel grotere bedrijven (met meer dan 100 ha of meer dan 150 koeien) in Flevoland toe. Dat aandeel is evenwel relatief kleiner ten opzichte van Noord-Nederland. Door de relatief hoge intensiteit in zowel de akkerbouw als de melkveehouderij in Flevoland worden in de provincie hoge saldi per ha en per koe gehaald. De noodzaak tot blijvend sterke schaalvergroting is daardoor wellicht wat kleiner dan in Noord-Nederland en de mogelijkheden daartoe zijn kleiner door de hoge grondprijzen. Overigens komen er in Flevoland ook enige grondloze melkvee-bedrijven voor. Daarnaast is de beweidingsgraad van melkkoeien in Flevoland relatief laag is ten opzichte van het gemiddelde in Nederland.

\section{Opvolgingssituatie en positie van gezinsbedrijven in Flevoland}

Ongeveer de helft van de agrarische ondernemers in Flevoland is, net als in de rest van Nederland, ouder dan 50 jaar. Zij hebben evenwel vaker een opvolger dan de collega's elders, in de melkveehouderij zelfs nog meer dan in de akkerbouw. Op de (overwegend) gezinsbedrijven, dus met 
de ondernemer als belangrijkste arbeidskracht op het bedrijf, wordt wel steeds meer arbeid van buitenaf ingehuurd. Op tuinbouwbedrijven was er altijd al personeel aanwezig, maar in alle andere bedrijfstypen was dat minder gebruikelijk. Mede door de toenemende omvang neemt ook buiten de tuinbouw de behoefte aan 'vreemde' arbeid op het bedrijf toe.

Het aantal bedrijven met een rechtspersoonlijkheid is in Flevoland iets lager dan op nationaal niveau. Het aandeel rechtspersonen op melkveebedrijven neemt wel snel toe en is ook hoger dan op de melkveebedrijven in Noord-Nederland. Dergelijke juridische vormen zijn bedoeld om gemakkelijker kapitaal aan te trekken en over te dragen. Door de toenemende bedrijfsomvang zoekt men hiervoor in toenemende mate mogelijkheden buiten het 'traditionele' gezinsbedrijf.

\section{Verbreding}

In Flevoland komt relatief meer verbreding voor dan gemiddeld in Nederland, vooral agrarisch natuurbeheer, ketenverkorting en huisverkoop. De opbrengst van deze activiteiten bleef in $60 \%$ van de gevallen beperkt tot minder dan $10 \%$ van de totale bedrijfsomzet. Een grensgeval wat betreft de definitie 'verbreding' is energieproductie, maar die komt in Flevoland ook relatief meer voor dan elders, vooral in de vorm van windenergie. Op een deel van de bedrijven voorziet verbreding in een deel van het inkomen. In $5 \%$ van de gevallen was de opbrengst uit verbreding meer dan $50 \%$ van de totale omzet.

\section{Grondposities en verkavelingssituatie}

In Flevoland neemt het aandeel 'grond in eigendom' geleidelijk aan toe. Pacht blijft echter een belangrijke vorm van grondgebruik. De grondprijs in Flevoland ligt hoger dan gemiddeld in Nederland, wat te maken heeft met het hoge opbrengende vermogen van de grond en de relatief goede structuur. Ondanks die goede structuur wordt de verkavelingsstructuur in Flevoland op 70 à $80 \%$ van het landbouwareaal als 'slecht' of 'matig' beoordeeld. Door diverse oorzaken zoals de aankoop van kavels 'op afstand' kan er een behoefte ontstaan aan bijvoorbeeld vrijwillige kavelruil.

\section{Biologische landbouw}

In Flevoland is een relatief groot aandeel van de bedrijven biologisch en dit aandeel stijgt ook nog eens relatief snel, met name in de sectoren buiten de akkerbouw en melkveehouderij (meer tuinbouwmatige bedrijven).

\section{Opbrengend vermogen van de grond en melkproductie per koe}

De meeste gewassen hebben in Flevoland een gemiddelde 10-15\% hogere kg-opbrengst dan gemiddeld over heel Nederland. Ook de melkproductie per koe is in Flevoland hoger dan gemiddeld in Nederland. De Flevolandse ondernemers combineren een hoogopbrengende grond met een hoog niveau van vakmanschap.

\section{Inkomensontwikkeling en saldi in de land- en tuinbouwsectoren}

De melkveebedrijven in Flevoland scoren qua inkomen uit bedrijf en financiële opbrengsten ongeveer even goed als vergelijkbare bedrijven elders in Nederland. Dat geldt ook voor de kosten en het saldo per koe. Door de grotere bedrijfsomvang en het grotere aantal koeien dan gemiddeld in Nederland komt in Flevoland het inkomen uit bedrijf hoger uit en ligt de kostprijs per kg melk lager dan elders; vergeleken met grote bedrijven elders liggen het inkomen en de kostprijs op hetzelfde niveau. In de akkerbouw liggen de gemiddelde geldopbrengsten per hectare in Flevoland fors hoger dan gemiddeld in Nederland. Maar omdat ook de kosten per ha hoger liggen dan elders komt het inkomen uit bedrijf per arbeidseenheid ongeveer op hetzelfde niveau uit als op de akkerbouwbedrijven elders in Nederland.

\section{GLB-toeslagen}

De akkerbouwbedrijven in Flevoland ontvangen relatief lage toeslagen per ha uit het Gemeenschappelijk Landbouwbeleid. Deze toeslagen zullen de komende jaren stijgen. De melkveebedrijven in Flevoland ontvangen relatief hoge bedrijfstoeslagen. Deze toeslagen zullen de komende jaren verder dalen. 


\section{Het agrocluster in Flevoland}

\subsection{Inleiding}

In dit hoofdstuk gaan we in op de bijdrage van het agrocluster in Flevoland aan de totale werkgelegenheid en de toegevoegde waarde in deze provincie. De primaire land- en tuinbouwsectoren zijn zowel aan de input kant (veevoer, kunstmest) als aan de output kant (verwerkende industrie) nauw verweven met andere sectoren in de economie. Het agrocluster is in deze studie gedefinieerd als het totaal van land- en tuinbouwbedrijven, visserij, voedings- en genotmiddelenindustrie en de aan deze sectoren toeleverende bedrijven. De werkgelegenheid en toegevoegde waarde van alle betrokken toeleverende bedrijven worden niet volledig meegenomen. Alleen het deel van hun omzet dat gegenereerd wordt uit toelevering aan de primaire sectoren en de verwerkende industrie wordt meegerekend in het agrocluster. In Bijlage 4 wordt verder ingegaan op de achtergronden, zoals gebruikte informatie en methodiek. Ook wordt nader ingegaan op definities en afbakening. In paragraaf 3.2 wordt de betekenis van het agrocluster beschreven. Ten slotte worden in paragraaf 3.3 een aantal conclusies getrokken.

\subsection{Betekenis van het agrocluster in Flevoland}

In Bijlage 4 is aangegeven dat het agrocluster in de definitie van het LEI bestaat uit de volgende drie hoofdsectoren: land- en tuinbouw, visserij en voedings- en genotmiddelenindustrie. Ook de toeleverende bedrijven worden, voor het deel dat ze toeleveren aan de drie hoofdsectoren, tot het agrocluster gerekend. Volgens de landbouwtelling van het CBS zijn er in Flevoland bijna 5.000 arbeidskrachten (in arbeidsjaareenheden, aje) werkzaam in de land- en tuinbouw. Hiervan is het grootste deel (38\%) werkzaam in de akkerbouw, gevolgd door $19 \%$ in de opengrondstuinbouw. Het aandeel van de intensieve veehouderij is met $3 \%$ het laagst. Flevoland heeft een aandeel van slechts $3 \%$ in het totale aantal arbeidskrachten werkzaam in de land- en tuinbouw in Nederland en behoort daarmee samen met Utrecht tot de kleinste provincies voor wat betreft het aantal personen die in de land- en tuinbouw werkzaam zijn. Met bijna 19\% van de totale werkgelegenheid in de visserij in Nederland (Urk) behoort Flevoland hierbij wel tot de grootste provincies. Voor de zee- en kustvisserij bedraagt dit percentage zelfs bijna een kwart (zie Tabel 3.1).

Tabel 3.1

Aantal werkzame personen in de visserij in Flevoland, 2013

\begin{tabular}{|c|c|c|c|}
\hline & Flevoland & Nederland & $\begin{array}{r}\% \text { Flevoland in } \\
\text { Nederland }\end{array}$ \\
\hline Zee- en kustvisserij & 558 & 2.415 & $23,1 \%$ \\
\hline Zeeviskwekerij & 1 & 51 & $2,0 \%$ \\
\hline Zoetwaterviskwekerij & 10 & 502 & $2,0 \%$ \\
\hline
\end{tabular}

Bron: LISA 2013.

In paragraaf 3.1 is al aangegeven dat de voedings- en genotmiddelenindustrie nauw verweven is met de primaire productiesectoren (landbouw, tuinbouw en visserij). Het ligt dan ook in de lijn der verwachting dat Flevoland op het gebied van akkerbouw, opengrondstuinbouw en visserij een relatief grote verwerkende industrie heeft en dat met name de slachterijen ondervertegenwoordigd zullen zijn. De cijfers uit het LISA-bestand (zie Tabel 3.2) bevestigen dit beeld. 
Tabel 3.2

Aantal werkzame personen in de voedings- en genotmiddelenindustrie in Flevoland, 2013

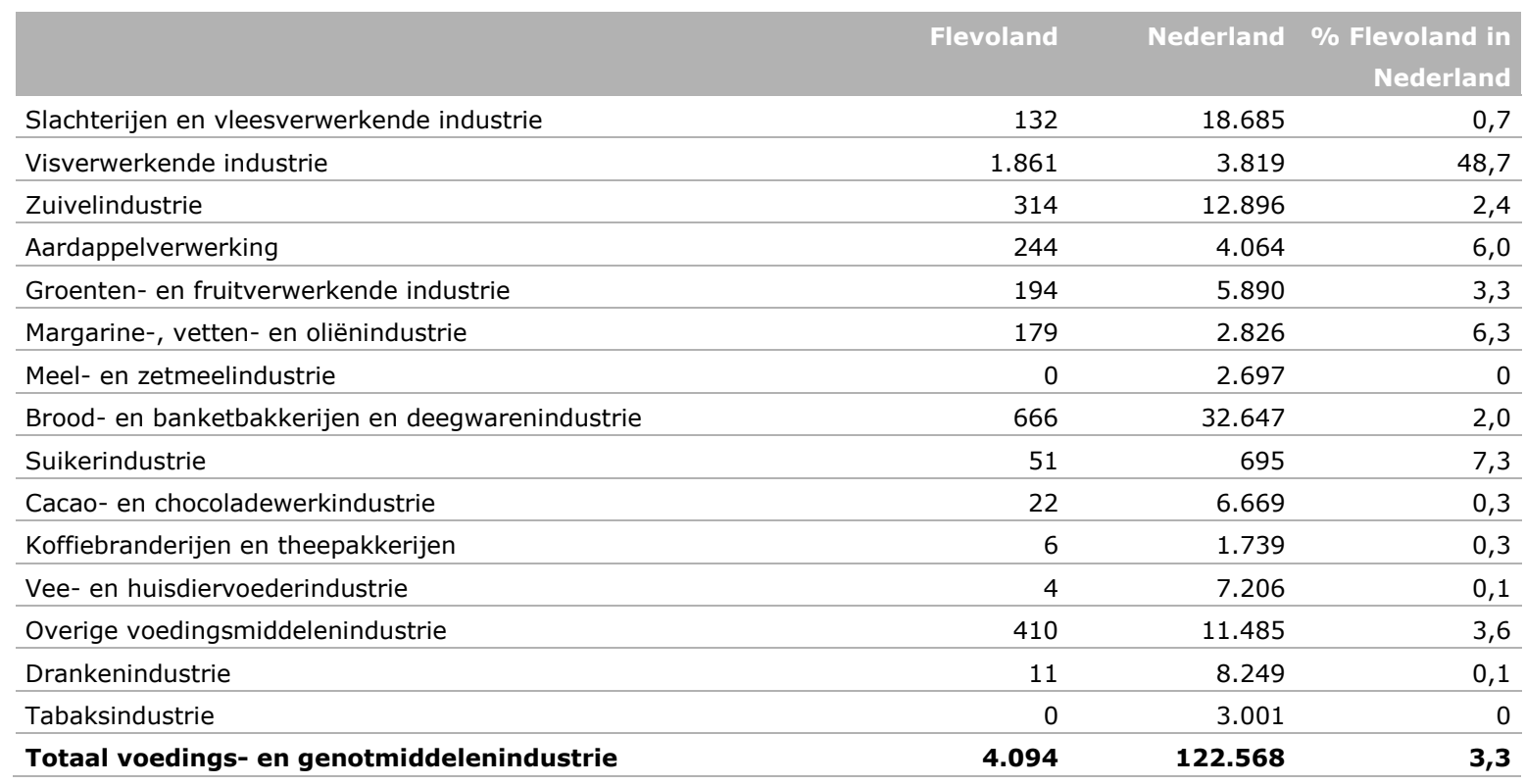

Bron: LISA 2013.

Los van de nauwe verwevenheid met de primaire sectoren kan de voedings- en genotmiddelenindustrie in een bepaalde provincie ook groot zijn door een strategische ligging (haven, vliegveld, rivier). Dit speelt vooral bij de verwerking van buitenlandse agrarische grondstoffen zoals koffie, thee, cacao en veevoedergrondstoffen.

Uit Tabel 3.2 blijkt dat bijna 50\% van de werkgelegenheid in Nederlandse visverwerkende industrie zich in Flevoland bevindt. Daarnaast werkt, volgens de LISA-gegevens, 6 à 7\% van de medewerkers in de Nederlandse verwerking van aardappelen en de productie van suiker, margarine, vetten en oliën in Flevoland. Flevoland levert hiermee een belangrijke bijdrage aan de nationale werkgelegenheid in die industrieën. De totale werkgelegenheid in de voedings- en genotmiddelen industrie in Flevoland bedraagt, net als die in de primaire land- en tuinbouw, ongeveer $3 \%$ van die in heel Nederland.

De totale toegevoegde waarde van alle economische activiteiten in Flevoland samen bedroeg volgens het CBS in 2013 ruim 10,5 miljard euro. Dit komt neer op minder dan $2 \%$ van de totale nationale toegevoegde waarde. Flevoland is daarmee, wat betreft toegevoegde waarde, na Zeeland de kleinste provincie. Ook het totale arbeidsvolume van Flevoland komt, met bijna 135.000 arbeidsjaren, uit op iets minder dan $2 \%$ van het Nederlandse totaal en is daarmee in 2013 de laagste van alle provincies.

Het totale agrocluster in Flevoland genereerde in 2013 ca 1,6 miljard euro toegevoegde waarde en ruim 20.000 arbeidsjaren werkgelegenheid. Het aandeel van het totale agrocluster, dus inclusief de op buitenlandse agrarische grondstoffen gebaseerde voedings- en genotmiddelenindustrie en de toeleverende bedrijven aan de agribusiness, in de totale economie van Flevoland ligt voor zowel toegevoegde waarde als de werkgelegenheid rond de $15 \%$ (Tabel 3.3). Vergeleken met het cijfer voor Nederland $(8 \%)$ is dit percentage voor Flevoland hoog te noemen. Dit hoge percentage wordt voor $11 \%$ veroorzaakt door de primaire land- en tuinbouwbedrijven, de op binnenlandse grondstoffen gebaseerde verwerkende industrie en de daarmee samenhangende toelevering en distributie. Aan deze $11 \%$ dragen de primaire productie en de toelevering het zwaarste bij. In het vervolg van deze paragraaf wordt dieper ingegaan op de in paragraaf 3.1 genoemde zes deelclusters. 
Tabel 3.3

Kerncijfers van het totale agrocluster in Flevoland, 2013

\begin{tabular}{|c|c|c|}
\hline & $\begin{array}{c}\text { Toegevoegde waarde } \\
\text { (m/n. euro) }\end{array}$ & $\begin{array}{c}\text { Werkgelegenheid } \\
\text { (arbeidsjaren) }\end{array}$ \\
\hline Agrocluster Flevoland, totaal & $1.624,4$ & $20.122,9$ \\
\hline \multicolumn{3}{|c|}{ Aandeel in totale economie van Flevoland van de: } \\
\hline Primaire productie & 495,3 & $6.521,2$ \\
\hline Toelevering & 410,6 & $5.099,7$ \\
\hline Distributie & 142,0 & $1.784,5$ \\
\hline
\end{tabular}

Bron: LEI, Agrarische input-outputtabel 2013.

\section{Akkerbouwcluster}

Het akkerbouwcluster is in Flevoland, met een bijdrage van bijna 47\% (Tabel 3.4) aan de toegevoegde waarde van het totale agrocluster, het belangrijkste deelcluster. Deze bijdrage ligt ongeveer op hetzelfde niveau als het landelijke gemiddelde. Dat hoge aandeel zien we ook terug bij de werkgelegenheid. Bijna 35\% van de werkgelegenheid in het totale agrocluster is toe te schrijven aan het akkerbouwcluster.

\section{Opengrondstuinbouwcluster}

Het opengrondstuinbouwcluster omvat in dit rapport de teelt en verwerking van opengrondsgroenten, fruit, bloembollen en boomkwekerijproducten, almede de aan deze sectoren toeleverende bedrijven. Dit cluster is na het akkerbouwcluster het tweede belangrijkste cluster in Flevoland. De bijdrage van dit cluster aan de toegevoegde waarde van het totale agrocluster in Flevoland is met bijna $15 \%$ ruim twee keer zo hoog als voor Nederland gemiddeld. Voor werkgelegenheid is het aandeel in de totale werkgelegenheid van het agrocluster in Flevoland zelfs ruim $21 \%$ (Tabel 3.4 ). Het totale opengrondstuinbouwcluster (inclusief de verwerking van buitenlandse groenten en fruit) is in Flevoland goed voor bijna $240 \mathrm{mln}$. euro toegevoegde waarde en ruim 4.200 arbeidsjaren werkgelegenheid. Hiervan is ongeveer $60 \%$ respectievelijk $70 \%$ direct afkomstig van de primaire landen tuinbouwsectoren. De verwerkende industrie is in dit cluster erg klein.

\section{Tabel 3.4}

Aandeel van afzonderlijke agrodeelclusters in totale agrocluster, 2013

\begin{tabular}{lrrrr} 
& \multicolumn{4}{c}{ Aandeel (\%) in: } \\
\cline { 2 - 5 } & Toegevoegde waarde in: & Werkgelegenheid in: \\
\cline { 2 - 5 } Akkerbouw & Flevoland & Nederland & Flevoland & Nederland \\
\hline Opengrondstuinbouw & 46,6 & 45,8 & 34,9 & 37,5 \\
\hline Glastuinbouw & 14,6 & 7,1 & 21,2 & 9,1 \\
\hline Grondgebonden veehouderij & 8,8 & 15,4 & 8,6 & 14,5 \\
\hline Intensieve veehouderij & 10,6 & 19,9 & 12,6 & 23,5 \\
\hline Visserij & 2,0 & 10,1 & 3,5 & 13,7 \\
\hline Totaal & 17,4 & 1,7 & 19,2 & 1,6 \\
\hline
\end{tabular}

Bron: LEI, Agrarische input-outputtabel 2013.

\section{Glastuinbouwcluster}

Het glastuinbouwcluster draagt in Flevoland met $9 \%$ beduidend minder bij aan de toegevoegde waarde en werkgelegenheid van het totale agrocluster dan gemiddeld in Nederland (16\%). Het totale glastuinbouwcluster (inclusief de verwerking van buitenlands groenten) is in Flevoland goed voor ruim $140 \mathrm{mln}$. euro toegevoegde waarde en ruim 1.700 arbeidsjaren werkgelegenheid. Hiervan is ongeveer $61 \%$ respectievelijk 55\% direct afkomstig van de primaire land- en tuinbouwsectoren. Net als bij het opengrondstuinbouwcluster draagt de verwerkende industrie zeer gering bij aan het totale resultaat. 
Grondgebonden veehouderijcluster

Het grondgebonden veehouderijcluster realiseert in Flevoland ruim $170 \mathrm{mln}$. euro toegevoegde waarde en iets meer dan 2.500 arbeidsjaren werkgelegenheid. De bijdrage aan het totale agrocluster in Flevoland is met bijna $11 \%$ bescheiden. Dit heeft te maken met het geringe aantal melkkoeien (minder dan $2 \%$ van het landelijk totaal) en het lage aantal zuivelverwerkende bedrijven en slachterijen (zie Tabel 3.2) in Flevoland. Landelijk gezien draagt het grondgebonden veehouderijcluster ruim $20 \%$ bij aan het Nationale agrocluster.

\section{Intensieve veehouderijcluster}

Het intensieve veehouderijcluster omvat in dit rapport het houden van dieren (kalveren, pluimvee, varkens) op intensieve wijze in stallen. Met uitzondering van pluimvee ( $2 \%$ van het nationaal totaal) komt de intensieve veehouderij in Flevoland nauwelijks voor (zie hoofdstuk 2). Ook zijn er bijna geen slachterijen in Flevoland (zie Tabel 3.2). De bijdrage van het intensieve veehouderijcluster aan de toegevoegde waarde en de werkgelegenheid van het totale agrocluster in Flevoland is daardoor met respectievelijk $2 \%$ en $3,5 \%$ dan ook gering.

\section{Visserijcluster}

Het visserijcluster draagt in Flevoland met ruim $280 \mathrm{mln}$. euro toegevoegde waarde en ruim 3.800 arbeidsjaren werkgelegen fors bij aan het totale agrocluster in Flevoland. Met een aandeel in de toegevoegde waarde en de werkgelegenheid van het totale agrocluster van respectievelijk $17 \%$ en $19 \%$ is dit cluster, na het akkerbouwcluster, het tweede cluster in belangrijkheid (Tabel 3.4). Dit wordt veroorzaakt doordat bijna $19 \%$ van de totale werkgelegenheid in de primaire visserij in Nederland (Tabel 3.1) zich in Flevoland bevindt. Daarbij komt ook nog, zoals Tabel 3.2 laat zien, dat bijna $49 \%$ van de landelijke werkgelegenheid in de visverwerkende industrie gerealiseerd wordt in Flevoland. Dit geeft aan dat Flevoland in het visserijcluster een prominente rol in neemt. Hierin zijn aanverwante activiteiten niet meegenomen, zoals scheepsbouw en reparatie, visserijbenodigdheden. De totale bijdrage van het landelijke visserijcluster in het landelijke agrocluster is overigens slechts circa $1,5 \%$.

\subsection{Conclusies}

De totale toegevoegde waarde van alle economische activiteiten in Flevoland samen bedroeg volgens het CBS in 2013 ruim 10,5 miljard euro. Dit komt neer op iets minder dan $2 \%$ van de totale nationale toegevoegde waarde. Flevoland is daarmee, wat betreft toegevoegde waarde, na Zeeland de kleinste provincie van Nederland. Ook het totale arbeidsvolume van Flevoland komt, met bijna 135.000 arbeidsjaren, uit op iets minder dan 2\% van het Nederlandse totaal en is daarmee in 2013 de laagste van alle provincies.

Het totale agrocluster (inclusief de voedings- en genotmiddelenindustrie die is gebaseerd op buitenlandse grondstoffen) in Flevoland genereerde in 2013 circa 1,6 miljard euro toegevoegde waarde en ruim 20.000 arbeidsjaren werkgelegenheid. Het aandeel van dit cluster in de totale economie van Flevoland ligt voor zowel toegevoegde waarde als werkgelegenheid rond de $15 \%$. Vergeleken met het vergelijkbare cijfer voor Nederland ( $8 \%$ ) is dit percentage voor Flevoland hoog te noemen.

Het akkerbouwcluster is, met een bijdrage van bijna $47 \%$ aan de toegevoegde waarde van het totale agrocluster in Flevoland, het belangrijkste agrodeelcluster. Dit ligt in lijn met het nationale beeld. Opvallend voor Flevoland is het grote aandeel van het visserijcluster en het opengrondstuinbouwcluster. Deze clusters hebben in het nationale agrocluster een zeer geringe bijdrage. Ten slotte valt op dat in Flevoland het aandeel van het grondgebonden veehouderijcluster, het glastuinbouwcluster en het intensieve veehouderijcluster relatief laag is.

De bijdrage van de diverse schakels (primair, verwerking, toelevering en distributie) binnen een cluster verschilt sterk van cluster tot cluster (Figuur 3.1). In het akkerbouwcluster en het visserijcluster wordt relatief veel toegevoegde waarde gecreëerd in de industrieën die toeleveren aan 
de verwerkende industrie. Dit hangt ook samen met de aanwezigheid van de verwerkende industrie in deze clusters.

In met name het glastuinbouwcluster en het opengrondstuinbouwcluster is de verwerkende industrie bijna niet aanwezig. Hier spelen de primaire land- en tuinbouwsectoren juist een belangrijke rol in de totstandkoming van de totale toegevoegde waarde van deze clusters. Voor het totale agrocluster in Flevoland dragen de primaire agrarische sectoren en de voedings- en genotmiddelenindustrie gezamenlijk ongeveer $50 \%$ bij aan de totale toegevoegde waarde. De overige $50 \%$ hangt samen met toelevering en distributie.

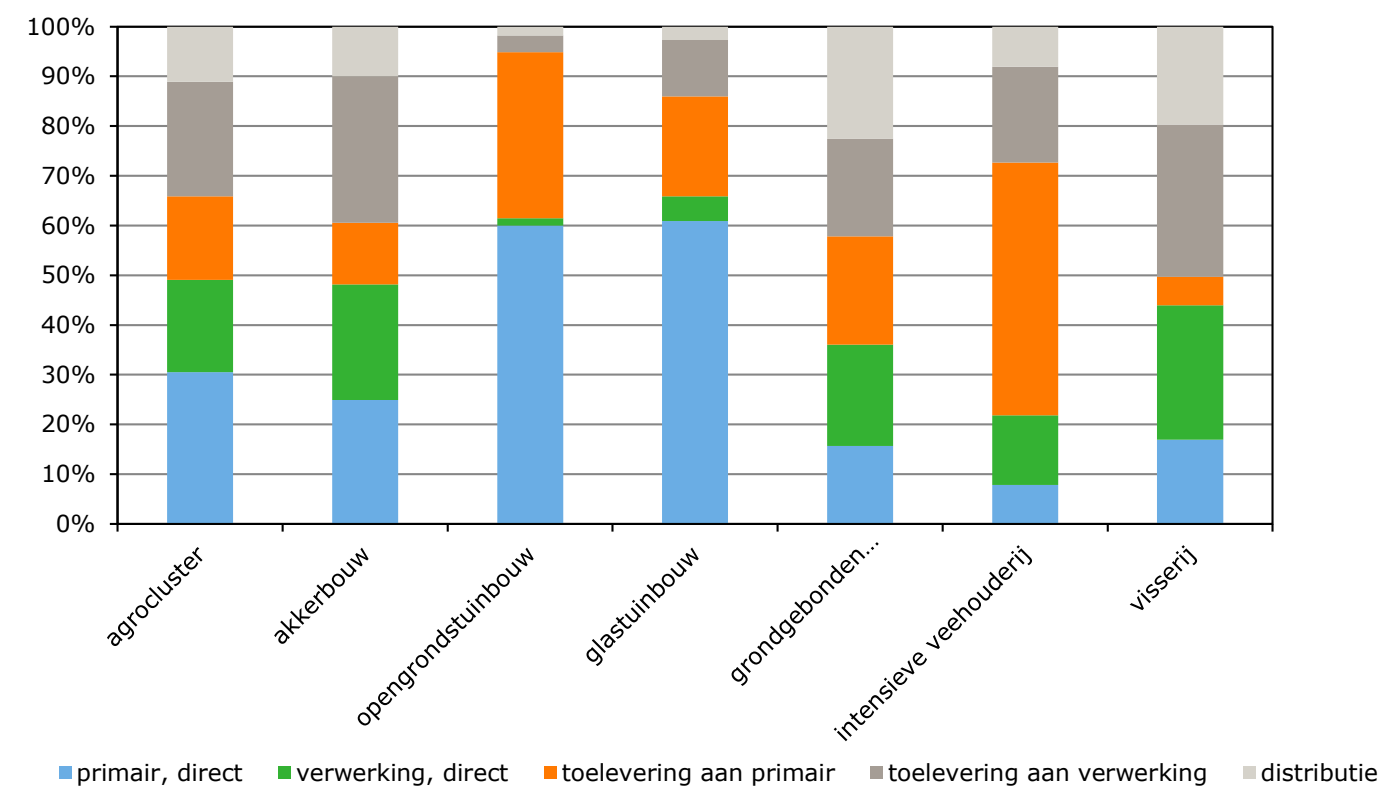

Figuur 3.1 Bijdrage van diverse schakels aan toegevoegde waarde van cluster in \%, 2013 


\section{$4 \quad$ Trends en ontwikkelingen in de agrosectoren (inclusief conclusies per sector)}

\subsection{Inleiding}

Dit hoofdstuk gaat in op de trends en ontwikkelingen vanuit markt en beleid die van invloed zijn op de agrarische sector in Flevoland. De gevolgen van die ontwikkelingen worden geschetst en concreet gemaakt door inschattingen te geven van de omvang van de diverse takken van land- en tuinbouw in Flevoland. Flevolandse landbouwproducten worden voor een groot deel afgezet op internationaal georiënteerde markten. Dit geldt overigens niet alleen voor Flevoland, maar is een algemeen kenmerk van de Nederlandse afzetmarkt van land- en tuinbouwproducten. Het overgrote deel van de land- en tuinbouwproductie in ons land productie vindt zijn weg naar andere EU-landen, vooral naar de buurlanden: Duitsland, België, Frankrijk en het Verenigd Koninkrijk. Zowel bij de invoer als bij de uitvoer is Duitsland de belangrijkste handelspartner. Van de Nederlandse agrarische export ging in 2014 bijna 26\% naar Duitsland, terwijl rond de 19\% van de agrarische importen uit Duitsland kwam.

De marktpositie van Flevolandse producten hangt dus sterk af van de vraag en het aanbod van die producten (elders) in Europa. Wat de vraagkant betreft, daarbij spelen ontwikkelingen binnen Europa een grote rol, zowel wat betreft demografische ontwikkelingen, koopkracht en specifieke wensen van consument en samenleving. De Europese markt kenmerkt zich door vergrijzing, lichte toename van de bevolkingsomvang en een bescheiden groei van de economie en de koopkracht. Aan de aanbodkant geldt dat Flevoland voor veel producten moet concurreren met teelt- en productiegebieden elders in Nederland en Europa. Er is geen aanleiding om aan te nemen dat die concurrentie af zal nemen, uitgezonderd mogelijk de afname van opbrengsten van een aantal gewassen in Zuid-Europa ten gevolge van klimaatverandering (minder neerslag en hogere temperaturen). De conclusie luidt dat de traditionele afzetmarkten van de Flevolandse producten grotendeels verzadigd zijn en dat men buiten Europa nieuwe markten zoekt en/of ontgint. De vraag naar landbouwproducten in andere delen van de wereld zal naar verwachting blijven toenemen, dankzij zowel een bevolkingsgroei in Azië, Afrika en Zuid-Amerika als een positieve koopkrachtontwikkeling in een aantal specifieke landen, zoals China en India.

Na deze analyse van de vraag- en aanbodfactoren die van invloed zijn op de toekomst van de Flevolandse land- en tuinbouwsectoren (marktontwikkelingen per sector), gaan we in op een aantal beleidsfactoren die daarbij een rol spelen. Die schetsen we in eerste instantie sectorspecifiek; in hoofdstuk 5 komen regionale factoren aan bod aan de hand van de thema's die in de Agenda Vitaal Platteland van de provincie aan de orde komen. Op basis van de analyse van die factoren en onze inschatting van de ontwikkeling van de verschillende sectoren komen we in hoofdstuk 6 tot een schets van het toekomstperspectief voor de land- en tuinbouw in Flevoland voor de komende 10 jaar.

\subsection{Akkerbouw en vollegrondsgroenten}

\section{Marktontwikkelingen}

Het overgrote deel van de akkerbouwproductie in Flevoland vindt - na bewerking - haar uiteindelijke bestemming over de Nederlandse grens. De meeste producten voor humane voeding worden afgezet binnen Europa, maar bijvoorbeeld pootaardappelen worden ook naar bestemmingen buiten Europa geëxporteerd. De markten voor akkerbouwproducten uit Flevoland worden dus primair bepaald door internationale ontwikkelingen.

Voor zover het bulkproducten betreft (graan voor voornamelijk veevoer, deels brouwgerst; suikerbieten voor suikerproductie, consumptieaardappelen voor frietproductie, uien voor de export, 
conserven voor de industrie) is het voor de verwerker (Suiker Unie, friet- en conservenindustrie, maalderijen, exporteurs) een plus dat er in Flevoland grote hoeveelheden uniform product verkrijgbaar zijn, op bedrijven met goede bereikbaarheid en bewaarfaciliteiten.

In producten voor humane voeding zijn daarbij geen grote ontwikkelingen te verwachten, al heeft Flevoland een goede naam wat betreft productkwaliteit. Voor Flevoland is de aardappelteelt economisch gezien zeer belangrijk. De (internationale) markten voor zowel pootaardappelen als consumptieaardappelen zijn groeiende. Vooral de wereldwijde toename van de vraag naar goede en moderne aardappelrassen in India, China en Oost-Afrika is significant. Het gaat dan niet primair om export van pootgoed, maar om aanbod van rassen in licentie, technologie (bijvoorbeeld in bewaring en mechanisatie) en consultancy. Een uitdaging daarbij is tot die markten door te dringen.

Bovenstaand beeld geldt ook voor uien. Hoewel Nederland een relatief kleine producent van uien is, behoort het na India tot de grootste uienexporteurs van de wereld (Bruns en Van de Brink, 2014). Negentig procent van de Nederlandse uienproductie wordt geëxporteerd. Binnen Nederland is Flevoland de grootste uienprovincie en zal dat waarschijnlijk ook wel blijven gezien de gunstige bedrijfsstructuur, geschikte grond en grote opslagcapaciteit. Dit gewas staat bekend om zijn zeer sterke prijsfluctuaties, met een drie- à vierjarige cyclus (één zeer goed jaar, één of twee gemiddelde jaren en één zeer slecht jaar). ${ }^{11}$ Gemiddeld gezien levert het gewas echter goede saldi op, zeker bij de goede kwaliteit die in Flevoland wordt voortgebracht. Het gaat daarbij met name om zaaiuien; maar ook voor eerste- en tweedejaars plantuien is ruimte, omdat zij gaten in het aanbod opvullen en daarmee goede verdiensten kunnen opleveren. Teelten als zilveruitjes blijven relatief klein en staan vooral in dienst van de conservenindustrie.

\section{Sectorspecifieke beleidsontwikkelingen}

In Europa is een toenemende vraag naar eiwithoudende gewassen. Wel is er met name vanuit ngo's kritiek op de grootschalige import van eiwithoudende producten, zoals soja uit landen als Brazilië. Uitbreiding van de teelt van dergelijke gewassen gaat daar gepaard met verlies van biodiversiteit, bijvoorbeeld in het Amazonegebied. Nederland in het algemeen en Flevoland in het bijzonder lenen zich echter niet als grootschalige teeltgebieden van eiwithoudende gewassen. Hun saldi zijn over het algemeen te laag om op de dure grond in Flevoland te kunnen concurreren met aardappelen, suikerbieten en uien. Op (veelal gemengde) biologische bedrijven spelen witte en andere klavers een rol in de eiwitvoorziening van de biologische veestapel. Dat areaal zou licht kunnen groeien bij een verdere groei van de biologische sector in de provincie.

$\mathrm{Er}$ is (inter)nationaal een toenemende belangstelling voor biobased (BBE-)grondstoffen, onder andere voor energietoepassingen, maar ook voor meer hoogwaardige toepassingen als vezels en chemische producten. De teelt van specifieke gewassen voor dit doel, zoals vezel- (vlas, hennep) en oliehoudende (koolzaad) gewassen ligt gezien de relatief lage saldi niet voor de hand, om vergelijkbare redenen als bij eiwitgewassen. Voor Flevoland ligt de BBE-verwerking van rest- en afvalstromen uit de diverse agrarische sectoren wel voor de hand. Inhoudsstoffen uit bijvoorbeeld aardappel- en bietenloof zijn wel onderzocht, maar de winning van die stoffen is momenteel nog niet economisch rendabel (Baltussen et al., 2015). De belangstelling voor BBE-toepassingen wordt door onder andere nationaal duurzaamheids-beleid (zoals het Energie-akkoord) gevoed, maar ook in de industrie is hiervoor aandacht, maar dan met toegevoegde waarde als belangrijkste drijfveer.

Toename van BBE-activiteiten kan gepaard gaan met een grotere afvoer van biomassa van de akker, bijvoorbeeld als hiervoor suikerbieten- of aardappelloof of (meer) graan-, erwten- of graszaadstro gebruikt gaat worden. ${ }^{12}$ Dat pakt dan negatief uit op de organische-stofbalans op de akker. Om de bodemgezondheid in Flevoland op peil te houden of, nog beter, te verbeteren zou het organischestofgehalte van de grond juist moeten toenemen. Afvoer van extra biomassa moet in dat geval (meer

\footnotetext{
${ }^{11}$ Ongewogen gemiddelde seizoenprijs van uien (euro/100 kg): 1999: 2; 2000: 7; 2001: 13; 2002: 10; 2003: 16; 2004: 1 2005: 9; 2006: 20; 2007: 9; 2008: 5; 2009: 20; 2010: 18; 2011: 2; 2012: 12; 2013: 18; 2014: 10.

${ }^{12}$ Een aantal van deze toepassingen is technisch mogelijk, maar de meeste zijn economisch nog niet rendabel (Baltussen et al., 2016).
} 
dan) gecompenseerd worden met aanvoer van extra organische stof in de vorm van compost of andere vormen van biomassa met lage bemestingswaarde. ${ }^{13}$

In een intensief bouwplan als in Flevoland zal men niet snel ruimte maken voor genoemde eiwit-, vezel- en oliehoudende gewassen. Naast saldo-overwegingen kunnen daarbij ook andere factoren een rol spelen, zoals het meerjarige karakter van hennepteelt en de kans op bodemziekten bij eiwithoudende gewassen.

Voor de aardappelteelt zijn geen beleidsmaatregelen te verwachten die de teelt sterk zullen doen inkrimpen. De kracht van het Nederlandse aardappelcluster, zowel voor poot- als voor consumptieaardappelen, is zo groot, dat een significante verschuiving van de aardappelteelt uit de polder naar andere lidstaten niet te verwachten is (Berkhout et al., 2015a). Plaatselijk kan de aardappelteelt onder druk komen te staan, namelijk waar in Flevoland bodemdaling een serieus probleem is. Een stijging van de grondwaterstand in die regio's kan aanleiding zijn om akker- in grasen natuurland om te zetten.

Voor de teelt van suikerbieten is van belang dat in 2017 het Europese suikerquotumsysteem afgeschaft wordt. Daardoor zal in (voornamelijk Noordwest-)Europa het suikerbietenareaal toenemen en de suikerprijs gaan dalen; dit heeft uiteraard zijn weerslag op de uitbetalingsprijs van suikerbieten (Smit et al., 2011). Suikerbieten zullen hierdoor ongetwijfeld minder concurrerend worden ten opzichte van aardappelen en uien. Het gewas blijft naar verwachting evenwel een stabiele inkomensfactor (zij het met meer prijs- en dus saldofluctuaties dan in het verleden). Voor Nederland als geheel denkt Suiker Unie aan een toename van het areaal van 20\% in 2018 (G. Sikken in Boerderij, oktober 2014). In Flevoland is het areaal suikerbiet is sinds 2006 geleidelijk aan gedaald en dat zou in 2018 weer op het oude niveau terug kunnen komen. Gezien het intensieve bouwplan in de NOP is daar geen groei van het suikerbieten- areaal te verwachten; in Oostelijk en Zuidelijk Flevoland is daarvoor meer ruimte. Er worden (grote) kansen gezien voor de suikerbiet als grondstof voor de biobased economy in ons land en dus ook in Flevoland (zie onder andere Deloitte, 2014).

Het nationale en Europese beleid zijn sterk gericht op een vergroting van de duurzaamheid van de agrarische sector. Voor de akkerbouw betekent dit vooral vermindering van het gebruik van meststoffen, gewasbeschermingsmiddelen en energie bij de teelt en opslag van de producten en vooral ook van de emissie van ongewenste stoffen, zoals nitraat naar oppervlakte- en grondwater en drift van chemische middelen naar de lucht. De sector heeft qua bemesting en gewasbescherming al grote vooruitgang geboekt (nadere informatie hierover is te vinden op www.agrimatie.nl). Gemiddeld genomen wordt het steeds moeilijker om gebruik en emissie nog verder te beperken.

Precisielandbouwtechnieken inclusief het gebruik van drones kunnen hierbij een goede rol spelen. Door goed in kaart te brengen hoe bodem en gewas er voor staan, kan tijd- en plaatsspecifiek maatwerk worden geleverd. De kosten van dergelijke technieken zijn relatief hoog, maar daar staan kostenbesparingen en vooral een betere lucht-, grond- en oppervlaktewaterkwaliteit tegenover (Janssens en Smit, 2000; Smit et al., 2000). Als bovendien een hogere kg-opbrengst per ha wordt behaald, neemt de efficiëntie van het middelengebruik extra toe (Brouwer et al., 2015). De sterke infrastructuur van de akkerbouw qua omvang en verkaveling gecombineerd met een hoog niveau van ondernemerschap in Flevoland maken de regio bijzonder geschikt voor precisielandbouw. De sector zelf is vooral met duurzamer gebruik van de bodem bezig. De grootste knelpunten zijn bodemverdichting en bodembiodiversiteit (Aequator, 2016 in voorbereiding).

Naast verbetering van het algemene efficiëntieniveau is het niveau van vakmanschap en management van een deel van de telers een aandachtspunt. In het Bedrijveninformatienet van het LEI blijken in iedere provincie grote verschillen in niveaus van meststof-, middelen- en energiegebruik tussen telers met vergelijkbare omstandigheden zoals bouwplan en grondsoort. Bewustwording en kennisontwikkeling ('Leven lang leren', zie Kortstee et al. (2011)) maar ook andere instrumenten

\footnotetext{
${ }^{13}$ Er zal op de meeste akkers gezien de mestwetgeving weinig ruimte zijn om organische mest aan te voeren. Als die ruimte er wel is, kan die natuurlijk ook daarmee ingevuld worden.
} 
kunnen nodig zijn om de negatieve effecten van matig vakmanschap en management bij een enkele teler voor het imago van de sector en de kwaliteit van het milieu zo veel mogelijk weg te nemen.

Aan energiegebruik is in de akkerbouw tot nog toe relatief weinig aandacht besteed. De akkerbouw is een relatief kleine energiegebruiker, al is het verbruik in de Flevolandse akkerbouw per ha relatief hoog (Brouwer et al., 2015). Dit onderwerp zal in het kader van het Nationale Energieakkoord meer aandacht gaan krijgen (Silvis et al., 2015). Het imago van de akkerbouw op energiegebied is evenwel relatief goed, zeker in Flevoland, door een relatief grote bijdrage aan duurzame energieproductie (wind- en zonne-energie). De verwachting is dat de productie van zonne-energie in Flevoland toe zal nemen, zowel op daken van agrarische bedrijfsgebouwen als op mogelijke zonneweides. Stimulans daarvoor is onder andere de recente subsidieregeling van het ministerie van EZ voor de sloop van asbestdaken van agrarische bedrijfsgebouwen en de vervanging daarvan door nieuwe daken, gecombineerd met zonnepanelen.

\section{Kansen voor Flevoland}

Wat de markt betreft is de positie van Flevoland voor de productie van hoogwaardige bulkproducten sterk, met name voor aardappelen, vollegrondsconserven, suikerbieten en uien. Voor deze gewassen blijft Flevoland een aantrekkelijk teeltgebied door de grote partijen product van goede kwaliteit die men uitstekend kan bewaren en eventueel sorteren, wassen en verpakken. Het hoge niveau van ondernemerschap draagt er aan bij dat de Flevolandse akkerbouwers flexibel in kunnen spelen op veranderende wensen van hun afnemers, die binnen de Europese verdringingsmarkt opereren. Voor een deel bevinden de verwerkers en exporteurs zich in Flevoland, maar producten als suikerbieten en granen worden nauwelijks in Flevoland verwerkt. De combinatie van een gunstige infrastructuur en het goede ondernemerschap van de boeren schept uitstekende mogelijkheden voor hoogwaardige en hoog-salderende producten. Dit is overigens ook noodzakelijk gezien de hoge grond- en pachtprijzen. Op de bedrijven zijn vaak voldoende faciliteiten (installaties en arbeid) aanwezig om tegemoet te komen aan de wensen van de afnemers. De akkerbouw heeft daarom een goede uitgangspositie om zich te handhaven op de sterk concurrerende markten. Veel verschuivingen in productassortiment zijn niet te verwachten.

\section{Bodemgezondheid}

Agronomisch gezien zijn er zorgen over de bodemgezondheid. Voor de teelt van pootaardappelen en bloembollen is een AM-vrijverklaring vereist, wat inhoudt dat er zich geen aardappelcystenaaltjes in de grond bevinden die tot de gevreesde aardappelmoeheid (AM) kunnen leiden. ${ }^{14}$ De vraag naar AM-vrije grond overtreft het schaarse aanbod, met een ware run op geschikte bollen- of aardappelgrond als gevolg. Oplossingsrichtingen voor dit belangrijke probleem bestaan uit de bestrijding van AM door beter management, een rassenpakket met voldoende resistenties op verschillende typen AM en nog meer samenwerking met melkveehouders door grondruil. Met deze inspanningen lijkt het probleem controleerbaar, ook op termijn.

\section{Poot- en consumptieaardappelen}

Pootaardappelen vormen een sterke sector in de Flevolandse land- en tuinbouw. Nederlands pootgoed heeft een redelijk goed imago, dat door kwaliteitsissues met onder andere Erwinia weliswaar wat onder druk staat, maar de concurrentiekracht vanuit Flevoland is dermate sterk dat er voor belangrijke concurrenten als Frankrijk, Schotland en Duitsland weinig gelegenheid is tot verdringing. De Flevolandse pootgoedtelers leveren goede kwaliteit, hebben veel geïnvesteerd in de pootaardappellijn en hebben een hoog ondernemerschapsniveau. De vraag naar pootgoed is structureel groot c.q. groeiende, met hoge opbrengstprijzen als gevolg.

Onder deze omstandigheden zal het voor de consumptieaardappel moeilijk worden zich volledig te handhaven in Flevoland, te meer daar frietaardappelen steeds meer op contractbasis (met een lagere toegevoegde waarde dan pootaardappelen) worden geteeld. Bovendien oefent het Veenkoloniale

\footnotetext{
${ }^{14}$ Aardappelmoeheid is een bekend voorbeeld van een zogenoemde quarantaineziekte of -organisme. Zodra een exportland aardappelcystenaaltjes op bijvoorbeeld Nederlands pootgoed ontdekt, gaat de grens voor dit product dicht. Ieder land wil voorkómen dat dergelijke zeer lastig te bestrijden, onuitroeibare organismen zich daar vestigen.
} 
gebied druk op de markt uit met dubbeldoelaardappelen (geschikt voor zowel friet- als zetmeelproductie), met een temperende werking op de vrije markt bij consumptieaardappelen als gevolg. Beide ontwikkelingen stimuleren geen uitbreiding van de consumptieaardappelteelt in Flevoland. De grens voor wat betreft het aardappelareaal is ongeveer bereikt, zeker in de NOP. Daarom zal een toename van de pootaardappel-teelt ten koste gaan van het consumptieaardappelareaal.

\section{Biobased Economy}

In Flevoland bestaat een flink aantal BBE-initiatieven op verwerkingsniveau (zie inventarisatie Janssens en Prins, 2013). De toenemende vraag naar grondstoffen voor de BBE zal naar verwachting akkerbouwers echter alleen aanspreken als het gaat om hoogsalderende speciaal-producten of om bijof afvalproducten. Onder die laatstgenoemde categorie doemen mogelijkheden op om bijvoorbeeld suikerbietenblad of aardappelloof via biobaks-initiatieven tot waarde te brengen. In de zogenaamde BBE-waardepiramide (zie onderstaande figuur) worden agrarische producten gerangschikt naar toepassingsgebied. Bovenin de piramide bevinden zich hoogwaardige producten voor gezondheid en dergelijke, met dienovereenkomstige hoge prijzen. Over het algemeen gaat het om producten waarvan de marktomvang beperkt is. Voorbeelden zijn producten voor de farmaceutische industrie en sierteelt-producten. Daaronder ligt de voedings- en diervoederlaag, met een wat lager prijsniveau maar grotere omvang. Vervolgens komt de laag waarin groene grondstoffen worden ingezet voor de productie van chemicaliën en materialen en tenslotte toepassing voor de productie van energie.

Qua energie liggen er in Flevoland zeker kansen voor een grotere bijdrage vanuit de akkerbouwsector aan de productie van wind- en zonne-energie. Vergisting biedt ook kansen, zeker wanneer op dit gebied samengewerkt wordt met de (melk-)veehouderij in de regio. Binnen de BBE-markt bestaat qua volume de meest omvangrijke vraag uit energie en chemicaliën en materialen. Deze productgroepen bevinden zich onderin de piramide. Voor de telers betekent dit dat zij tegen een lage kostprijs grote hoeveelheden moeten kunnen leveren. De telers zullen dus rekening moeten houden met geldopbrengsten per ha die laag tot zeer laag zijn: over het algemeen dus vergelijkbaar met of lager dan de laagstsalderende gewassen (granen) op dit moment. Daar liggen in theorie kansen voor groei van de afzet van Flevo-landse akkerbouwproducten, mits de keten voor hernieuwbare producten goed op gang komt en bijvoorbeeld suikerbiet een concurrerende c.q. prijstechnisch aantrekkelijke grondstof blijkt te zijn; dit is nog niet bij voorbaat zeker (Harmsen et al., 2014). Met name de Suiker Unie is zich op dit vlak nog aan het oriënteren. Het is niet ondenkbaar dat zij hun BBE-grondstoffen gaan maken uit relatief laagwaardige pulp (Baltussen et al., 2015). Dat zou de toegevoegde waarde van de suikerbiet verhogen en aantrekkelijk zijn voor de telers. Die weg zou dan echter geen extra areaal suikerbieten in Flevoland vragen. ${ }^{15}$

In ieder geval zal een eventuele vraag naar agrarische rest- en afvalstromen voor BBE-toepassingen vanuit de verwerkende industrie komen (mogelijk breder dan de verwerkers van agrarische producten $\mathrm{sec}$ ) en die is beperkt aanwezig in Flevoland zelf. Een dergelijke ontwikkeling heeft dus relatief weinig effect op de economie van Flevoland. Mogelijk neemt het saldo van diverse teelten licht toe door een betere verwaarding van rest- en afvalstromen. Als echter de prijzen voor deze rest- en afvalproducten (te) sterk stijgen, schakelt de betreffende verwerker over op andere grondstoffen. Op deze manier blijft BBE een marginaal verschijnsel voor de regionale en bedrijfseconomie, tenzij er de komende jaren technologische doorbraken gerealiseerd worden en er nieuwe businessmodellen ontstaan. In dat opzicht liggen er wellicht kansen in de verwaarding van inhoudsstoffen en (kleinschalige) bioraffinage.

\footnotetext{
${ }^{15}$ Wel zou een reden voor Suiker Unie voor uitbreiding van het areaal een grotere voorzieningsgraad van de Europese suikerverwerkende industrie kunnen zijn, die onder het huidige quotumsysteem een deel van haar suikerbehoefte met importen van buiten de EU moet invullen (Smit et al., 2011).
} 


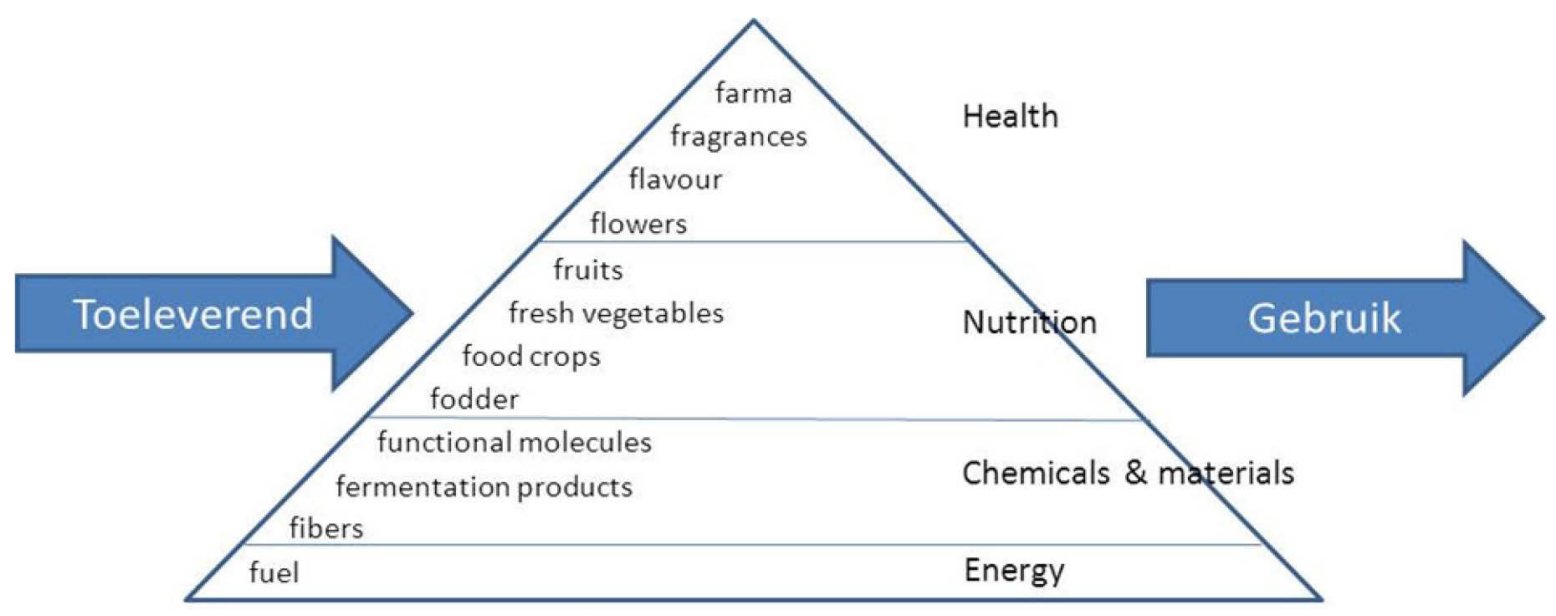

Figuur 4.1 Waardepiramide van groene grondstoffen naar gebruiksdoel

Bron: Wetenschappelijke en Technologische Commissie voor de Biobased Economy, 2013.

\section{Conclusies}

- De arealen van de bestaande gewassen zullen de komende jaren niet sterk veranderen.

- Er is wel een groei te verwachten van het pootgoedareaal ten koste van de teelt van consumptieaardappelen. Uien zullen in areaal doorgroeien en vollegrondsconserventeelten zullen stabiliseren.

- De oppervlakte granen zal kleiner worden ten gunste van grasland en snijmais.

- Er liggen zeker kansen voor een grotere bijdrage vanuit de akkerbouwsector aan de productie van wind- en zonne-energie. Vergisting biedt ook kansen, zeker wanneer op dit gebied samengewerkt wordt met de (melk)veehouderij in de regio.

- De productie van grondstoffen voor de biobased economy zal beperkt blijven tot reststromen en bijproducten van vooral de verwerkende industrie, maar er liggen de komen jaren wellicht wel kansen voor inhoudsstoffen en (kleinschalige) bioraffinage.

- De opbrengstprijs van suikerbieten zal naar beneden gaan. Naar verwachting blijft het saldo echter voldoende op peil, zodat eerder een uitbreiding dan krimp van het areaal verwacht mag worden.

- Precisielandbouw zal de komende decennia een algemene trend worden als middel om de inzet van meststoffen en gewasbeschermingsmiddelen en eventuele milieubelasting als gevolg daarvan te beperken.

\subsection{Bloembollenteelt}

\section{Marktontwikkelingen}

Nederland is wereldmarktleider voor bloembollen. De markt voor bloembollen is op dit moment redelijk goed, maar omdat het een 'luxeproduct' is (non-food) is de teelt afhankelijk van de algemene economische ontwikkelingen en van een voortzetting van het herstel van de wereldeconomie. Het Nederlandse areaal bloembollen schommelt sinds 2005 tussen 23.000 en 24.500 ha (Agrimatie.nl), wat met de economische schommelingen samenhangt. Voor de komende jaren wordt herstel van de wereldeconomie verwacht, wat positief uit zal werken voor de vraag naar bloembollen.

\section{Sectorspecifieke beleidsontwikkelingen}

Op duurzaamheidsgebied mogen globaal dezelfde ontwikkelingen verwacht worden als in de akkerbouw Beperking van bemesting, gewasbescherming en energiegebruik blijft of wordt (in het geval van energiegebruik) een belangrijk aandachtspunt voor alle opengrondsectoren. Daarbij heeft de bloembollenteelt niet per definitie een goed imago, gezien ook de 'omwonenden-problematiek' (Berkhout et al., 2014). Het absolute niveau van gewasbeschermingsmiddelengebruik is veel hoger dan in de akkerbouw en melkveehouderij. Dat geeft zorgen bij bewoners van aan bloembollenpercelen grenzende bebouwing. Maatschappelijk verantwoord ondernemen is bij deze problematiek een belangrijke voorwaarde om te kunnen blijven bestaan. Gezien de lage bevolkingsdichtheid in Flevoland zal dit geen probleem vormen. 


\section{Kansen voor Flevoland}

Bloembollen worden in Flevoland voor een deel geteeld door Noord-Hollandse telers. De verhuur van Flevolandse akker- en grasland voor bollenteelt levert de betreffende Flevolandse akkerbouwers en veehouders geld op en de samenleving 'bollenroutes', maar dat deel van de economische bedrijvigheid en bijbehorende inkomsten komt buiten Flevoland terecht. Door de nettenteelt is de teelt minder grondsoortafhankelijk geworden. Daardoor is er vraag naar bollengrond in Flevoland gekomen. Net als voor de pootaardappelen is voor de teelt van bloembollen AM-vrije grond vereist. Vanwege de schaarste aan deze grond wordt voor geschikte bollengrond hoge huurprijzen betaald.

Voor de bloembollentelers uit Flevoland zelf geldt dat zij, zoals vermeld in paragraaf 2.4, over het algemeen grote, efficiënte bedrijven hebben. Verwacht mag worden dat zij zich in verhouding met collega's in met name dichtbevolkte gebieden in West-Nederland een concurrentievoordeel hebben op het gebied van bedrijfsstructuur en uitbreidingsmogelijkheden. Het bloembollenareaal in Flevoland zal daarom toenemen, mogelijk ten koste van de traditionele teeltgebieden in Noord- en Zuid-Holland.

\section{Conclusies}

- Een voortgaand herstel van de wereldeconomie mag verwacht worden, wat positief zal uitpakken voor de vraag naar bloembollen.

- Zowel de lokale telers als de verhuurders van bollengrond in Flevoland zullen daarvan profiteren.

- Het areaal bollengrond in Flevoland zal naar verwachting verder groeien.

\subsection{Glastuinbouw}

\section{Marktontwikkelingen}

De markten voor glasgroenten zijn de laatste jaren sterk wisselend, maar gemiddeld niet bijzonder perspectiefvol als gevolg van overproductie; alleen nichemarkten (zoals cherrytomaten) tonen ruimte voor groei. Ook de glasbloementeelt heeft bij tijd en wijle te maken met een onbalans in vraag en aanbod. Sinds 2015 verloopt de afzet weer iets gemakkelijker, vooral als gevolg van een toenemende vraag vanuit Engeland en Noord-Amerika. Afzetmarkten in het Verre Oosten zijn nog in ontwikkeling. De potplantenteelt heeft nog het meeste perspectief, mits soorten worden geteeld waar vraag naar is en de teler, bijvoorbeeld via winkelformules een goed afzetkanaal weet te regelen (Smit et al., 2009; Brouwer et al., 2015).

\section{Sectorspecifieke beleidsontwikkelingen}

Het areaal glastuinbouw in Nederland zal de komende jaren voor de meeste producten afnemen. Het aanbod aan groenten en snijbloemen is structureel te groot; voor potplanten zijn vraag en aanbod goed op elkaar afgestemd. Door deze situatie zijn de inkomens in de glastuinbouw (uitgezonderd potplantenteelt) al jaren slecht en worden vervangingsinvesteringen uitgesteld. Nieuwbouw van kassen is helemaal zeldzaam geworden. In deze situatie is verplaatsing van een glastuinbouwbedrijf uit het Westland naar bijvoorbeeld Flevoland lastig; het oude bedrijf is moeilijk te verkopen. Hier en daar worden oude glastuinbouwgebieden gesaneerd. De uitgekochte ondernemers zullen een nieuwe plek zoeken, waarbij diverse factoren van belang zijn zoals bereikbaarheid, infrastructuur, grondprijs en beschikbaarheid van arbeidskrachten. Daarbij gaat het om grote kavels, omdat het leveren van grote partijen uniform product toch als een succesfactor van de Nederlandse glastuinbouw wordt gezien (Berkhout et al., 2015a). Blijkbaar voldoet de Noordoostpolder aan deze eisen, want in de afgelopen vijf jaar hebben zich diverse bedrijven hier gevestigd.

Intussen blijft een lage kostprijs voor het grootste deel van de glastuinbouw in Flevoland van essentieel belang om te overleven. Daarnaast blijft het een grote uitdaging om tot product-, procesen markt-innovatie te komen, al zal dat niet direct tot verandering van de gehele sector leiden (Smit et al., 2015).

\section{Kansen voor Flevoland}

De glastuinbouw in Flevoland is geconcentreerd rond Luttelgeest en Marknesse. De stichting Nieuwland is opgericht door een initiatiefgroep, die de betrokkenen bij de glastuinbouw in dit gebied vertegenwoordigd. Volgens deze stichting betreft dit momenteel 207 ha glas, waaronder zowel 
glasgroenten (tomaat, paprika, komkommer) als bloemen en potplanten worden geteeld. Daarnaast komt rond Ens nog eens 50 ha glastuinbouw voor. Ondanks de afname van de landelijke oppervlakte glastuinbouw is deze in de Noordoostpolder volgens de stichting sinds 2010 met ongeveer 160 ha gegroeid. Deze groei is vooral te danken aan glasgroentetelers die zich vanuit andere delen van Nederland hier hebben gevestigd, zoals beschreven in de vorige paragraaf. Rond Luttelgeest hadden zij de mogelijkheid om voor een relatief gunstige prijs mooie rechthoekige en grootschalige kavels te verkrijgen. Ook goede infrastructuur, de stimulering van de geothermische warmte-installaties en de medewerking vanuit de overheid droegen in positieve zin aan bij de ontwikkeling van het gebied. In het gebied is nog ruimte voor ongeveer 100 ha glastuinbouw.

Een derde glastuinbouwcentrum is gevestigd in de gemeente Almere. Hier gaat het volgens informatie van de website www.tobiasbromelias.nl/Nieuws/43/Duurzaam_Collectief_Buitenvaart.html) om een totale oppervlakte glas van ongeveer 80 ha. ${ }^{16}$

Flevoland biedt dus zeker ruimte voor nieuwkomers en heeft daar ook sterke papieren voor gezien de beschikbaarheid van personeel en goede grond, de ruimte, de bereikbaarheid, de infrastructuur en de relatief korte afstand tot de centra voor kennis en afzet in West-Nederland (en de achterblijvende familie aldaar). De mate waarin nieuwkomers daadwerkelijk naar de NOP zullen komen is afhankelijk van ontwikkelingen in de glastuinbouw zelf (met name van de vraagontwikkeling, onder andere vanuit Rusland, en van de mate waarin innovaties lukken) en de mate waarin overheden en projectontwikkelaars in met name het Westland bestaande glastuinbouwbedrijven opkopen en saneren. Naar verwachting zal er een gematigde stroom van nieuwkomers zijn en is het glastuinbouwgebied bij Luttelgeest niet op korte termijn vol.

\section{Conclusies}

- Het kassengebied in de Noordoostpolder biedt ruimte voor verdere ontwikkeling. Vooral voor nieuwkomers die een locatie zoeken van bovengemiddelde omvang zijn hier vestigingsmogelijkheden. Hiervoor is nog zeker 100 ha beschikbaar.

- Naar verwachting zal er een gematigde stroom van nieuwkomers zijn en is het glastuinbouwgebied bij Luttelgeest niet op korte termijn vol.

\subsection{Melkveehouderij}

\section{Marktontwikkelingen}

De zuivelmarkt krijgt een steeds sterkere internationale oriëntatie. De wereldhandel in zuivelproducten wordt voor 2015 geraamd op 74 miljoen ton melkequivalent, 2,7\% meer dan in 2014. De belangrijkste exporteurs zijn Nieuw-Zeeland en de EU, die samen iets meer dan $50 \%$ van de wereldhandel voor hun rekening nemen. Voor beide wordt een hogere afzet verwacht. Ook de afzet van de Verenigde Staten neemt verder toe, bovenop de forse groei die in 2013 is gerealiseerd. Azië zal naar verwachting het belangrijkste afzetgebied blijven voor de internationale handel, met verhoogde aankopen door China, Indonesië, Maleisië en Thailand. Ook Saoedi-Arabië, de Verenigde Arabische Emiraten, Japan, de Filippijnen en Singapore blijven belangrijke afzetmarkten; hier wordt geen groei voorzien en in sommige gevallen zelfs een daling. De lagere prijzen zijn een stimulans voor

\footnotetext{
${ }^{16}$ Over de oppervlakte glastuinbouw in Flevoland circuleren verschillende cijfers. De CBS-Landbouwtelling komt in 2014 in totaal op 160 ha, waarvan het grootste deel (127 ha) in de Noordoostpolder. Volgens Stichting Nieuwland komt in de Noordoostpolder ongeveer 250 ha glas voor. Samen met 80 ha in Almere zou de totale oppervlakte glas ongeveer 300 à 350 ha zijn. Bij de provincie Flevoland circuleert een getal van minimaal 500 ha glastuinbouw. Dat getal correspondeert met een tabel van het CBS over 'Terrein voor glastuinbouw'. Deze oppervlakte nam toe van 161 ha in 1991 tot 494 ha in 2010 (het laatst beschikbare jaar;

http://statline.cbs.nl/Statweb/publication/?DM =SLNL\&PA=70262NED\&D1=0,25\&D2=0,5-

$16 \& D 3=a \& H D R=T, G 2 \& S T B=G 1 \& V W=T)$. Vermoedelijk betreft dit het areaal dat voor glastuinbouw is bedoeld maar nog niet is volgebouwd (helemaal duidelijk is dit niet). Overigens is in de NOP het totale areaal 'tuinbouw onder glas' de afgelopen jaren toegenomen, terwijl deze in met name Dronten en Almere relatief het sterkst is afgenomen (http://statline.cbs.nl/Statweb/publication/?DM=SLNL\&PA=80781NED\&D1=45$54 \& D 2=9,150,262,414,493,624,703 \& D 3=0,6, I \& H D R=G 1, G 2 \& S T B=T \& V W=T)$.
} 
de afzet in Afrika. Algerije, Egypte en Ghana zijn daar de belangrijkste importeurs; hun vraag groeit. Daartegenover staat een lagere afzet in de Russische Federatie als gevolg van de economische recessie en boycot (Berkhout et al., 2015b).

De afschaffing van het Europese melkquotum heeft in Nederland en ook in Flevoland tot extra productie geleid. Daarom is er momenteel overproductie met lage prijzen. Op langere termijn kunnen nieuwe afzetmogelijkheden worden gezocht, maar het 'laaghangend fruit' is deels al geplukt (Zuidoost-Azië) en ook daar zit de lokale zuivelproductie in de lift. De Nederlandse zuivel blijft wel een sterke partij op de zuivelmarkt door het hoge niveau van voedselveiligheid en kwaliteit. Voor Nederland als totaal verwachten Jongeneel et al. (ongepubliceerd) een sterke invloed van het fosfaatquotum. Daardoor zal het aantal melkkoeien de komende jaren slechts beperkt kunnen groeien. Wel verwacht men dat de trend in de stijging van de melkproductie per koe zich onverminderd zal voortzetten.

Apart punt van aandacht is de mestverwerking. Er zijn in het verleden al enkele tientallen initiatieven geweest in het hele land om op boerderijniveau via monovergisting van mest energie op te wekken. Deze ontwikkeling werd sterk gestimuleerd door de Stimuleringsregeling Duurzame Energie (SDE) van het ministerie van EZ, maar toen de subsidies naar beneden geschroefd werden, verminderde de rentabiliteit van deze installaties drastisch. Recent heeft minister Kamp van EZ aangegeven dat hij toch weer monovergisting op boerderijniveau via deze regeling wil gaan stimuleren. Deze ontwikkeling wordt ook vanuit de zuivelindustrie in ons land ondersteund omdat men daar het streven heeft om op termijn klimaatneutraal te produceren. Friesland Campina zoekt in dit verband ook samenwerking met regionale afvalbedrijven om via grotere installaties waar meerdere boeren betrokken zijn gezamenlijk energie te gaan produceren. Daar liggen dus ook kansen voor de melkveehouderij in Flevoland.

\section{Kansen voor Flevoland}

Een trek van melkveehouders vanuit andere regio's naar Flevoland is onwaarschijnlijk. Voor hen ligt de grondprijs in Flevoland te hoog in vergelijking met andere delen van Nederland. In een enkel geval zal een 'uitgekochte' veehouder van het oude land zich in Flevoland gaan vestigen. De grotere bestaande melkveehouders hebben de afgelopen jaren reeds geanticipeerd op afschaffing van het melkquotum. Dit was mede mogelijk vanwege de goede bedrijfsresultaten in de melkveehouderij in 2013 en 2014. Een deel van de bedrijven heeft stalruimte bijgebouwd en heeft deze deels al gevuld met extra melkvee. Een ander deel heeft geïnvesteerd in grond in afwachting op de ontwikkelingen na afschaffing van het quotum. Door de huidige dip in de economische situatie in de melkveehouderij zal de groeispurt vertraagd worden, maar de ambitie van veel melkveehouders om op termijn de bedrijfsomvang te vergroten zal hierdoor nauwelijks worden beïnvloed. Voor de komende jaren kan worden verwacht dat de kleinere bedrijven (tot ongeveer 50 melkkoeien) zullen stoppen c.q. overgenomen zullen worden door de grotere en dat de grotere bedrijven (sterk) zullen groeien. Deze intensivering van de productie zal gepaard gaan met toenemende grondruil met akkerbouwers, zodat de melkveehouders toch de benodigde hoeveelheid ruwvoer uit de regio zullen kunnen betrekken. Een intensievere samenwerking met melkveehouders heeft voor akkerbouwers het voordeel dat er meer AM-vrije grond beschikbaar komt voor de teelt van aardappelen en dat er een ruimer bouwplan gevoerd kan worden, met een hoger aandeel bodemverbeterende gewassen.

\section{Conclusies}

- Het aantal melkveehouders in Flevoland zal de komen jaren afnemen.

- Het aantal melkkoeien neemt tot 2025 naar verwachting toe met hooguit $10 \%$.

- De melkproductie per koe zal blijven stijgen.

- De melkproductie per ha zal naar verwachting toenemen.

- Grondruil met akkerbouwers zal verder toenemen. 


\subsection{Varkenshouderij}

\section{Marktontwikkelingen}

In de varkenshouderij is een onbalans tussen vraag en aanbod van varkensvlees ontstaan, onder andere door de Russische boycot. Nederland gaat nu naarstig op zoek naar nieuwe afzetgebieden, zoals China. Tegelijkertijd is de eigen Chinese varkenssector ook in opmars. Aan de andere kant, de Chinese bevolking groeit in absolute aantallen snel en bij een toenemend welvaartspeil stijgt bovendien de vleesconsumptie per inwoner. Ook aan de productiekant lijkt Nederland de grens te hebben bereikt. Vooral de afzet van de mest tegen een aanvaardbare prijs is problematisch. Dit probleem wordt nog versterkt door de te verwachten groei van de melkveestapel. Voor de totale Nederlandse varkenssector wordt een krimp verwacht (Jongeneel et al., ongepubliceerd).

De Flevolandse varkensbedrijven maken moeilijke tijden door. Ook op de langere termijn is de kans op nieuwkomers in Flevoland klein. Een van de redenen is dat de basis om in Flevoland varkens te gaan houden wankel is. Toeleveranciers en afnemers met kennis van de varkenshouderij zijn schaars.

\section{Kansen voor Flevoland}

Naar verwachting zal er weinig tot geen nieuwvestiging in Flevoland plaatsvinden; mogelijk wel schaalvergroting.

\section{Conclusies}

- De varkenshouderij in Flevoland heeft het moeilijk; ook op termijn is het perspectief onzeker.

- Instroom van varkenshouders is hoogst onwaarschijnlijk; een vermindering van het aantal varkensbedrijven ligt meer voor de hand.

\subsection{Pluimveehouderij}

\section{Marktontwikkelingen}

Momenteel wordt circa 35\% van de Nederlandse eierproductie geëxporteerd als broedei, waarbij Rusland veruit de belangrijkste bestemming is. Ook voor de slachterijen en uitsnijderijen is de export belangrijk. Verse kipdelen (kipfilet) worden geëxporteerd naar Duitsland en het VK, terwijl voor bevroren producten (poten en bouten) landen in Afrika en Azië belangrijke bestemmingen zijn (citaat uit Berkhout et al., 2015). De export is vooral gericht op afzet van hoogwaardige kipfilet naar de omringende landen. Daarnaast is er een substantiële import van kuikenvlees (vooral bevroren kipfilet) uit Brazilië en, in mindere mate, uit Thailand. Dit vlees vindt vooral zijn bestemming naar de verwerkende industrie (citaat uit Berkhout et al., 2015b). De EU is in overleg met een aantal landen om via bilaterale handelsakkoorden te komen tot meer vrijhandel. Het overleg met de VS binnen het zogenaamde TTIP-overleg krijgt daarbij veel aandacht. De Europese pluimveevleessector kan niet concurreren op kostprijs met lage kosten landen zoals de VS, Brazilië en Argentinië (Van Horne, 2014). In de huidige situatie wordt de Europese pluimveevleessector beschermd door een stelsel van quota en invoerheffingen. Bij een substantiële verlaging van de invoerheffingen zal de invoer uit derde landen toenemen waardoor de positie van de Europese industrie verder verzwakt zal worden (citaat uit Berkhout et al., 2015b).

De vraag naar pluimveevlees neemt jaarlijks toe. Met name onder Noordwest-Europese consumenten groeit de aandacht voor dierwelzijnsaspecten. De Nederlandse vleeskuikensector vertaalt deze wensen met een transitie naar een meer diervriendelijke productie, met meer aandacht voor de productkwaliteit voor het versmarkt-segment. De eiermarkt is op Europees niveau verzadigd. Bovendien zien we ook in de legsector een trend naar de vraag om diervriendelijke productie. Evenals onder de varkenshouders is ook onder de pluimveehouders weinig animo zich in Flevoland nieuw te vestigen.

\section{Kansen voor Flevoland}

Naar verwachting zal er weinig tot geen nieuwvestiging in Flevoland plaatsvinden; mogelijk wel schaalvergroting. 


\section{Conclusie}

Instroom van pluimveehouders in Flevoland zal naar verwachting nauwelijks plaatsvinden.

\subsection{Biologische landbouw}

\section{Marktontwikkelingen}

De consumptie van biologische producten zit al jarenlang in de lift in ons land, maar ook daarbuiten in West-Europa. (Bron: Monitor Duurzame Landbouw). In 2012 en 2013 was de jaarlijkse groei wat lager maar kwam nog steeds uit op ruim 5\% per jaar. Dit geeft aan dat de biologische landbouw zich mag verheugen in een toenemende belangstelling. Het aandeel van de biologische landbouw binnen de totale consumptie van voedingsproducten ligt op ongeveer $2 \%$ à $2,5 \%$ en groeit gestaag. Voor de naaste toekomst mag verwacht worden dat de omzet voor deze sector verder zal stijgen; ook het te verwachten herstel van de koopkracht van Nederlandse consumenten zal hieraan bijdragen. Een belangrijke ontwikkeling richting doorgroei van de biologische sector is dat de retail steeds meer ruimte geeft aan dit segment. Doortrekken van de trends van de afgelopen jaren en rekening houdend met effecten van conjunctuurherstel mag verwacht worden dat vraag naar biologisch landbouwproducten over vijf à tien jaar ongeveer $30 \%$ hoger zal zijn dan nu het geval is.

\section{Kansen voor Flevoland}

De hierboven geschetste verwachting dat de omzet van biologische landbouwproducten het komende decennium zal blijven groeien biedt kansen voor de ontwikkeling van de Flevolandse biologische sector. De randvoorwaarden om op deze marktgroei in te spelen zijn zeker aanwezig in de provincie.

\section{Conclusies}

Momenteel is ruim $8 \%$ van het landbouwareaal in Flevoland in gebruik van biologische telers; verwacht wordt dat de biologische landbouw zich richting 2025 verder uit zal breiden tot circa $15 \%$ van het areaal. 


\section{$5 \quad$ Omgevingsfactoren uit de Agenda Vitaal Platteland}

\section{$5.1 \quad$ Inleiding}

In dit hoofdstuk wordt beschreven hoe de in hoofdstuk 4 beschreven feiten en ontwikkelingen zich verhouden tot de discussies over het plattelandsbeleid, zoals die in Flevoland momenteel spelen. Dit wordt gedaan aan de hand van een analyse van een aantal omgevingsfactoren uit de Agenda Vitaal Platteland (Provincie Flevoland, 2015). In deze agenda zet de provincie puntsgewijs haar visie over de toekomst van het platteland uiteen. De Agenda beschrijft een 17-tal zogenoemde agendapunten, waarmee de provincie een vitaal platteland wil behouden en versterken. Van deze 17 punten worden er 7 als urgent aangemerkt; die punten worden in dit hoofdstuk nader uitgewerkt en verbonden met de analyses in voorgaande hoofdstukken. Op enkele andere punten gaan we globaal in. Op basis van de analyse van die punten en onze inschatting van de ontwikkeling van de verschillende sectoren komen we in hoofdstuk 6 tot een schets van het toekomstperspectief voor de land- en tuinbouw in Flevoland voor de komende 10 jaar.

\subsection{Leefbaarheid}

De Leefbaarometer geeft een samengestelde indicator voor de leefbaarheid op verschillende niveau, variërend van provincie- tot postcodeniveau. Er zijn zes dimensies onderscheiden waaraan de leefbaarheid wordt afgemeten: woningvoorraad, publieke ruimte, voorzieningen, bevolkingssamenstelling, veiligheid en aanwezigheid van natuur. De leefbaarheid in de wijken wordt gekwantificeerd door vergelijking met het Nederlands gemiddelde.

Over het algemeen ligt de leefbaarheidsscore in Flevoland boven het landelijk gemiddelde (Tabel 5.1). De Noordoostpolder en Urk scoren goed op bevolkingssamenstelling, veiligheid en woningvoorraad. Het niveau van voorzieningen ligt daarentegen onder het gemiddelde. Tussen de dorpen zijn de verschillen in het algemeen klein. Hetzelfde beeld geldt ook voor Dronten en Zeewolde, al is daar de sociale samenhang beneden het landelijk gemiddelde. Lelystad en Almere scoren gemiddeld beduidend lager. Problemen aldaar zijn de onevenwichtige bevolkingssamenstelling, de sociale samenhang en de veiligheid. De variatie binnen deze twee gemeenten is overigens groot. De buitengebieden scoren zeer goed, maar bepaalde stadswijken, zoals Almere Poort, slecht.

De leefbaarheid van het platteland (inclusief de dorpen en stadsranden) wordt in grote mate beïnvloed door agrarische activiteiten. Het aanzien van het platteland wordt voor een groot deel bepaald door de inpassing van de huidige landbouw binnen de provincie. Regionaal zijn er wel verschillen in landinrichting: de veelzijdigheid van de NOP onderscheidt zich van het grootschalige en rechthoekige karakter van de Flevopolder. Vooral de dorpen hebben een sterke verbinding met het platteland, en dus ook met de landbouw. In vele facetten van het dagelijkse gebeuren komt de dorpeling in aanraking met de landbouw. De landbouw is een van de economische dragers van de dorpen (directe en indirecte werkgelegenheid). Dit belang neemt in de toekomst wel af door doorgaande schaalvergroting, mechanisering en automatisering. Het aantal agrarische ondernemers neemt verder af evenals het totaal aantal arbeidskrachten in de primaire landbouw. Mogelijk vormt de glastuinbouw in de Noordoostpolder hierop een uitzondering.

Op de meeste bedrijven zullen weinig burgers komen, omdat er door de professionalisering van de landbouw toch een zekere kloof tussen burgers en boeren is ontstaan. Een uitzondering hierop vormen de verbrede landbouwbedrijven, voor zover ze inspelen op de behoeften van burgerpubliek. Voor de leefbaarheid van Flevoland is het belangrijk voldoende ruimte te geven aan de boer-burger-relaties die door verbrede landbouwactiviteiten worden bevorderd. 
Als het goed gaat met de landbouw, dan zal het ook goed gaan met het onderhoud van gebouwen, erven en landerijen. De landbouw in Flevoland heeft goede perspectieven, maar de schaalvergroting gaat door. Dat betekent ook dat een deel van de boerderijen en erven in handen is of zal komen van niet-landbouwers. Het is niet altijd vanzelfsprekend dat dit het onderhoud van gebouwen en erven ten goed komt. Dit aspect verdient aandacht bij het thema 'vrijkomende erven', zoals verder uitgewerkt in paragraaf 5.3.

De leefbaarheid van met name de dorpen hangt ook voor een groot deel samen met de rest van de economie. Voor de werkgelegenheid en daarmee voor de leefbaarheid van het platteland hoeft een verdere afname van het aantal agrarische ondernemers en medewerkers geen probleem te vormen als andere vormen van economische activiteit er floreren.

\section{Tabel 5.1}

Leefbaarheid in de verschillende gemeentes in Flevoland ten opzichte van het Nederlands gemiddelde ( minimale score per onderdeel $=-50$, maximale score is +50 , landelijk gemiddelde $=0$ )

\begin{tabular}{|c|c|c|c|c|c|c|c|}
\hline Gemeente & Totaal score & $\begin{array}{r}\text { Samenstelling } \\
\text { bevolking }\end{array}$ & $\begin{array}{r}\text { Sociale } \\
\text { samenhang }\end{array}$ & $\begin{array}{r}\text { Publieke } \\
\text { ruimte }\end{array}$ & Veiligheid & $\begin{array}{r}\text { Voorzieningen- } \\
\text { niveau }\end{array}$ & $\begin{array}{l}\text { Woning- } \\
\text { voorraad }\end{array}$ \\
\hline NOP & zeer positief & 12 & 0 & 0 & 30 & -8 & 10 \\
\hline Dronten & zeer positief & 14 & -5 & 0 & 28 & -7 & 20 \\
\hline Zeewolde & zeer positief & 23 & -16 & 7 & 30 & -27 & 19 \\
\hline Almere & positief & -19 & -17 & -5 & -18 & -8 & 1 \\
\hline Nederland & positief & 0 & 0 & 0 & 0 & 0 & 0 \\
\hline
\end{tabular}

Bron: Leefbaarometer, 2012

\subsection{Vrijkomende erven}

Dit onderzoek bevestigt de bevindingen van Gies et al. (2014), die verwachten dat het komende decennium steeds meer boerenerven zullen vrijkomen. De belangrijkste oorzaak daarvan ligt bij de schaalvergroting in de sector, waarbij de grond van stoppende bedrijven toegevoegd wordt aan die van de blijvers en de bijbehorende bedrijfsgebouwen (deels) aan de landbouw worden onttrokken.

Vanwege de van oorsprong kleinschaliger landbouwstructuur is het aantal vrijkomende bedrijfsgebouwen in de Noordoostpolder naar verwachting het grootst. De vrijkomende gebouwen worden veelal hergebruikt als woning, waarbij de eigenlijke bedrijfsgebouwen worden gebruikt voor hobbydoeleinden (dieren, autoverzameling, andere ruimte vragende hobby's), voor opslag of voor werkruimte voor ZZP-ers. De verkoop van deze gebouwen was de afgelopen jaren lastig, mede door de algemene economische crisis. Ook momenteel is het aanbod van agrarische gebouwen groter dan de vraag, ondanks de redelijk soepele interpretatie van de bestemmingsplannen door de gemeenten. Leegstand komt in de praktijk (nog) niet voor, maar er gaat over het algemeen veel tijd over heen voordat er voor te koop staande (losse) agrarische gebouwen een koper gevonden wordt. In Oostelijk en Zuidelijk Flevoland is de problematiek minder groot, maar ook daar maakt de bedrijfsontwikkeling een aantal boerenerven op termijn overbodig. In de nabijheid van grotere plaatsen vinden deze bedrijfsgebouwen gemakkelijker een koper dan op de meer afgelegen plekken.

In de toekomst zullen jaarlijks naar verwachting enige tientallen agrarische bedrijfsgebouwen in Flevoland aan de landbouw onttrokken worden als gevolg van de doorgaande schaalvergroting in de landbouw in combinatie met het ontbreken van een opvolger op een deel van de bedrijven. Tot op heden is er geen sprake van leegstand, in tegenstelling tot andere provincies in ons land. Om de leefbaarheid van het platteland goed te houden is het belangrijk ook in de toekomst leegstand te vermijden. Hiervoor zullen waarschijnlijk extra maatregelen nodig zijn, zoals verruiming van de 
bestemmingsplannen (bijvoorbeeld toelaten van detailhandel) of een 'rood voor rood'-regeling, waarbij agrarische bedrijfsgebouwen mogen worden afgebroken ten behoeve van woningbouw.

Wat betreft de agrarische structuur, de doorgaande schaalvergroting in de sector, eventueel in combinatie met verbetering van de verkavelingssituatie door bijvoorbeeld kavelruilprojecten, is 'grondmobiliteit' nodig, dat wil zeggen dat (landbouw)grond relatief gemakkelijk geruild c.q. ge- en verkocht kan worden. Deze grondmobiliteit wordt gestimuleerd als stoppende ondernemers op een goede manier van hun bedrijfsgebouwen af kunnen komen.

De verkavelingsstructuur in Flevoland is de afgelopen jaren verslechterd (DLG, 2014). De overblijvende bedrijven groeien, maar een deel van de extra grond wordt aangekocht, gepacht of gehuurd op afstand. Daardoor neemt het agrarische verkeer in intensiteit toe. Dit werkt kostprijsverhogend, is slecht voor duurzaamheidsaspecten als brandstofgebruik en luchtkwaliteit en belast het wegennet. Daar staat tegenover dat het een vorm van risicospreiding kan zijn. Voor een deel is dit onvermijdelijk, omdat het samenhangt met een voortgaande trend van specialisatie, waarvan het gebruik van 'los land' en jaarhuur een onderdeel is. Dat zorgt voor 'gezonde' dynamiek in de sector. Aan de andere kant is het voor bedrijven met een minder gespecialiseerd bouwplan aantrekkelijk om de rijafstanden te beperken en de grond dichter bij huis te hebben. Door de toenemende bedrijfsomvang moet men slagvaardig de werkbare dagen kunnen benutten. Tijdverlies door grote transportafstanden staat daar haaks op. Ook is het gemakkelijker om dicht bij huis de grond, de gewassen en het weer in beeld te hebben dan op afstand. Voor de leefbaarheid van Flevoland is ook de verkeersveiligheid op zowel de provinciale als 'boerenwegen' een punt van aandacht. Minder rijden is dan beter.

\subsection{Ontsluiting landelijk gebied}

De doorgaande schaalvergroting leidt ertoe dat de tractoren en machines steeds groter worden en dat steeds meer ondernemers percelen 'op afstand' pachten of bezitten (zie paragraaf 5.3). Daardoor zal de hoeveelheid zwaar landbouwverkeer op de plattelandswegen toenemen, met toenemende risico's qua verkeersveiligheid, geluidshinder en schade aan wegen en bermen. Deze constatering impliceert een toenemende noodzaak voor zorg/alertheid/activiteiten voor de wegbeheerder in overleg met onder andere LTO. Voor een deel gaat het om gemeentelijke wegen en is de rol van de Provincie daarbij beperkt. Naar verwachting zullen maatregelen nodig zijn om de verkeersdoorstroming en veiligheid in de provincie te verbeteren. Daarnaast kunnen initiatieven op het terrein van kavelruil en dergelijke het aantal verkeersbewegingen en de gemiddelde reisduur verminderen, zoals in paragraaf 5.3 beschreven.

De landbouw zal toenemende behoefte hebben aan snel internet. Dat hangt samen met de mogelijkheden die ICT, eventueel in combinatie met precisielandbouw, biedt om de bedrijfsvoering verder te optimaliseren. Die optimalisatie is ook nodig, gezien de noodzaak om tot hogere opbrengsten te komen met lagere inzet en emissies van meststoffen, gewasbeschermingsmiddelen en energie.

\section{$5.5 \quad$ Bodemdaling}

Bodemdaling komt op meerdere locaties in Flevoland voor. In deze bodemdalingsgebieden zal de landbouw moeten leren omgaan met nattere bodemomstandigheden. Akkerbouwgrond zou bijvoorbeeld kunnen worden omgevormd tot grasland, dat veel beter tegen natte omstandigheden bestand is. Deze verandering betekent dus een verandering in bedrijfsopzet en doet daarmee een beroep op het ondernemerschap van de telers, zoals dat nu al gebeurt bij het voormalige eiland Schokland. Door agrarische en aanverwante functies zoals natuurbeheer en andere vormen van verbrede landbouw te combineren is er in dergelijke gebieden voor meerdere ondernemers wel een boterham te verdienen. Daarmee kunnen de negatieve gevolgen van de bodemdaling voor de 
regionale economie beperkt worden. Wel moet rekening gehouden worden met een waardedaling van grond en gebouwen ter plaatse.

\subsection{Kansen in de keten}

Hoewel Flevoland centraal in Nederland is gelegen en de primaire landbouwproductie gericht is op hoogwaardige rooivruchten, die een verdere be- of verwerking moeten ondergaan, speelt de meeste verwerking zich buiten de provincie af. Uit logistieke overwegingen en vanuit werkgelegenheidsoogmerk zou extra verwerking in de provincie welkom zijn. Een toenemend aantal ondernemers probeert binnen de huidige bedrijfsomvang (qua areaal) extra inkomsten te genereren door zelf landbouwproducten te be- of verwerken. Die bewerkingen bestaan bijvoorbeeld uit bewaren, wassen, snijden of verpakken van de producten. Ook boerderijverkoop van eigen producten kan als zodanig worden gezien. Dit biedt economisch gezien meerwaarde, zowel op bedrijfsniveau als voor de regionale economie. Door de verdere schaalvergroting en specialisatie zullen de kansen voor be- en verwerking op het eigen bedrijf verder toenemen. Er zullen daardoor grotere hoeveelheden product beschikbaar komen voor 'verwaarding'. Dit betekent voor de overheid onder andere dat er voldoende ruimte moet zijn voor vergroting van bouwblokken. Zowel de schaalvergroting als de extra bewerkingen op het bedrijf zelf vragen om meer ruimte voor opslag, sorteren, verladen, enzovoort.

\subsection{Pionieren 2.0}

De term Pionieren 2.0 houdt volgens de Agenda Vitaal Platteland de volgende ontwikkelingen in:

- versterking van het innovatieve vermogen van agrarisch ondernemers;

- versterking van de duurzaamheid;

- versterking van de multifunctionaliteit van het landelijk gebied.

Indien duurzaamheid wordt gedefinieerd als evenwicht tussen de elementen People, Planet en Profit liggen de drie genoemde punten in elkaars verlengde. De in dit hoofdstuk geschetste ontwikkelingen stellen de land- en tuinbouwers voor uitdagingen, waarvoor zij al hun innovatief vermogen aan zullen moeten spreken. In het bijzonder geldt dit voor zaken die meer een beroep doen op het ondernemerschap dan op vakmanschap, zoals transitie naar biologische landbouw, ketenverkorting of multifunctionele landbouw. Daarnaast zal duurzaam bodembeheer extra aandacht van de ondernemers vergen.

De provincie stimuleert in overleg met de sector het innovatief vermogen van de agrarische ondernemers. Dit dient ook een maatschappelijk doel, namelijk de leefbaarheid van het platteland. Het ligt daarbij voor de hand aan te sluiten bij de kennisinstellingen die in de provincie aanwezig zijn, zoals het Groenhorstcollege, CAH Vilentum Hogeschool, de Warmonderhof, Wageningen UR, Agrofoodcluster Emmeloord en het Agrarisch Innovatie Netwerk Flevoland. Deze instellingen kunnen helpen om voor de genoemde uitdagingen oplossingsrichtingen op maat te zoeken, te ontwerpen en toe te passen.

In dergelijke processen kan het innovatievermogen van agrariërs in sommige gevallen de regelgeving van de diverse overheden te boven gaan. Anders gezegd, men komt tot oplossingen die wettelijk niet toegestaan zijn, omdat de ontwikkelingen in de praktijk sneller gaan dan de wetgever kon voorzien. In de praktijk doet zich dit voor als het bijvoorbeeld het bouwblok moet worden vergroot om een gebouw te plaatsen voor het wassen en verpakken van groentes of als regelgeving het plaatsen van een windmolen in de weg staat. In Flevoland lijkt de maximale omvang van het bouwblok overigens nog geen belemmering voor innovatieve bedrijfsontwikkeling.

\subsection{Uitbreidingsmogelijkheden veehouderij}

De AVP geeft aan dat er mogelijkheden zijn tot uitbreiding van de veehouderij. Uit dit onderzoek blijkt dat een significante instroom van veehouderijbedrijven van buiten de provincie niet te verwachten is. 
Uitbreiding van de veestapel is veeleer een gevolg van ontwikkeling van bestaande bedrijven. De ontwikkelingsdrang van met name melkveebedrijven is redelijk groot, ondanks de huidige slechte economische resultaten en de beperkingen van de in te voeren fosfaatrechten. Deze groeidrang zal echter afgeremd worden door de melkveewet en de invoer van fosfaatrechten. Deze nieuwe wetgeving kan er wel toe leiden dat de concurrentie om grond tussen melkvee- en akkerbouwbedrijven toeneemt. Ook mag verwacht worden dat een deel van het (beperkt) aantal intensieve veehouderijbedrijven in de provincie hun bedrijf zal willen uitbreiden. Milieutechnisch hoeft dat geen probleem te zijn als aan de regelgeving (onder meer de PAS) wordt voldaan. Uiteraard heeft uitbreiding van de veestapel in Flevoland maatschappelijke consequenties, die deels al in de voorgaande paragrafen zijn genoemd, zoals een behoefte aan (betere) ontsluiting, toename van het aantal transportbewegingen en een noodzaak tot bouwblokvergroting.

De verwachte (bescheiden) groei van de veestapel in de komende jaren is goed voor de regionale economie in Flevoland. Met name de melkveebedrijven zullen hun krachtige positie in de provincie behouden, mits zij de investeringen in grond en fosfaatrechten weten te beperken. Maar juist in Flevoland liggen hiervoor veel kansen door samenwerking met akkerbouwers. Ook de leefbaarheid van de provincie zal niet te lijden hebben onder de groei van de veestapel. Die groei zal echter niet automatisch leiden tot meer koeien in de wei. Voor verhoging van het percentage beweiding zijn aanvullende maatregelen nodig (zoals een hogere melkprijs), waarbij de zuivelverwerkers in principe een hoofdrol spelen.

\subsection{Overige punten uit de AVP}

De reeds behandelde punten worden in de AVP als urgent aangemerkt. Daarnaast noemt de AVP enkele overige punten die voor de land- en tuinbouw van belang zijn. Die worden hier kort behandeld. Deze punten zijn:

\section{- Schaalvergroting}

In de AVP wordt onderscheid gemaakt tussen gezins- en 'grootbedrijven'. Schaalvergroting in de landbouw is een autonoom proces, dat nauwelijks stuurbaar is door de provincie. Voor een sterke landbouw is het noodzakelijk om binnen de maatschappelijke context goede randvoorwaarden voor verdere ontwikkeling van de landbouw te scheppen, zoals hierboven al benoemd. Omdat schaalvergroting lang niet altijd gerealiseerd kan worden door aankoop van grond die grenst aan of ligt in de nabijheid van het bestaande bedrijf treedt in de praktijk versnippering op. De noodzaak om hiervoor oplossingen te bedenken is beschreven in paragraaf 5.3.

\section{- Erfgrootte}

In tegenstelling tot vele andere provincies is in Flevoland geen maximum gesteld aan de erfgrootte en het bouwblok. Gezien de te verwachten ontwikkelingen in de sector (schaalvergroting, ketenverkorting, meer multifunctionele landbouw) zal de behoefte aan bouwblokvergroting toenemen, zoals eerder in dit hoofdstuk beschreven.

\section{- Recreatie en toerisme}

Naast ontwikkelingen als schaalvergroting en specialisatie zal een (klein) deel van de bedrijven in Flevoland zich toeleggen op verbrede landbouw, waaronder recreatie en toerisme. Met dergelijke activiteiten zijn bijvoorbeeld een aantal bedrijven in gebieden met bodemdaling geholpen, zoals in paragraaf 5.5 beschreven.

\section{- Natuur}

Natuurontwikkeling valt onder de verantwoordelijkheid van de provincie. De Flevolandse natuur drijft vooral op grootschalige natuurgebieden. Ook wat betreft natuur- en landschapselementen in het polderlandschap is de overheid de belangrijkste speler. Denk daarbij bijvoorbeeld aan de bomenrijen langs de wegen of de natuurvriendelijke oevers van kanalen. Voor landbouw is wat dit betreft een minder belangrijke taak weggelegd. Er ligt geen doelstelling om de hoeveelheid natuur te vergroten. Het aanspreekpunt voor agrarisch natuurbeheer zijn de Agrarische Natuurverenigingen (ANV). In het Flevolands Agrarisch Collectief werken zes ANV's samen. De provincie heeft hierbij een 
grote rol omdat zij contracten met het collectief afsluit, in eerste instantie alleen voor het agrarisch natuurbeheer, maar op termijn wellicht ook voor andere groene en blauwe diensten.

Natuurontwikkeling en -beheer passen in het algemeen beter bij verbrede bedrijven dan bij ondernemers die vooral inzetten op schaalvergroting en specialisatie. Deze twee dominante trends zullen in het algemeen op gespannen voet staan met aandacht voor natuur. Iedere extra hectare natuur betekent namelijk een hectare minder landbouwgewassen. Bestuurlijke aandacht voor zowel de landbouw als voor natuur betekent keuzes maken en integratie van landbouw en natuur bevorderen.

\section{- Landschap, cultuurhistorie, archeologie en erfgoed}

Buiten de voormalige eilanden Urk en Schokland gaat het hierbij beleidsmatig vooral om minder belangrijke aangelegenheden. Te noemen valt dat erfbeplanting in Flevoland verplicht is, dat men cultuurhistorische waarde hecht aan schokbetonnen schuren, neergestorte vliegtuigen en opgegraven schepen uit prehistorische tijden. Deze aandacht staat haaks op trends als schaalvergroting en specialisatie, waarbij het vooral gaat om grote bedrijven, rechthoekige kavels, perfecte ontsluiting en afwatering enzovoort. Bestuurlijke aandacht voor zowel de landbouw als voor landschap en dergelijke betekent keuzes maken en integratie van landbouw en landschap bevorderen.

\section{- Bodem en water}

Staps et al. (2015) stellen dat de bodemkwaliteit in Flevoland momenteel ernstig wordt bedreigd. De Flevopolder staat bekend om zijn zeer vruchtbare gronden. Toch is op veel plaatsen binnen één generatie de bodemkwaliteit verminderd door verslechtering van de bodemstructuur. Door deze structuurverslechtering wordt het steeds moeilijker om op zware gronden een bouwplan toe te passen dat voldoende saldeert voor het benodigde bedrijfsrendement.

De akkerbouwer staat hierbij steeds meer in een spanningsveld tussen korte- en lange-termijnbelangen. Hij ervaart vanuit de markt een druk op winstmaximalisatie op de korte termijn. Deze focus op de korte termijn geeft weinig ruimte voor het behoud van de bodemkwaliteit op de lange termijn. De hoge grond- en pachtprijzen in de provincie dragen bij aan deze focus op de korte termijn, zoals ook beschreven door Berkhout et al. (2015b, Bodemkatern). De provincie kan wellicht helpen om de grond als belangrijkste productiemiddel de lange termijn aandacht te geven die nodig is voor het behoud van het opbrengend vermogen. Ook uit het oogpunt van klimaatverandering is er noodzaak om de bodemstructuur te verbeteren, vooral in verband met de toekomstige behoefte aan een groter waterbergend vermogen in de bodem. De dominante ontwikkelingsrichtingen in de akkerbouw (schaalvergroting en intensivering) leiden eerder tot vergroting dan tot oplossing van de bodemproblemen. Immers, de geconstateerde oorzaken daarvan (natuurlijke bodemrijping, hoog aandeel rooivruchten, veel bodembewerking met zware machines, weinig aanvoer van organische stof en de focus op het kortetermijnbelang vanwege de hoge pachtprijzen) worden door de te geschetste ontwikkelingen op het gros van de bedrijven niet automatisch omgebogen. Hier ligt dan ook een belangrijke opgave die om een gezamenlijke inzet vraagt. Wellicht kan de provincie hiervoor een apart onderzoeks- en stimuleringsprogramma opzetten. Een consequentie van de bodemproblematiek kan zijn dat verdergaande specialisatie wordt afgeremd, maar dat juist op bouwplanverbreding en extensivering wordt ingezet. In eerste instantie kunnen dergelijke maatregelen de regionale- en bedrijfseconomie afremmen; op langere termijn worden die juist geconsolideerd.

\subsection{Conclusies}

\section{Leefbaarheid}

De leefbaarheid op het platteland van Flevoland is goed te noemen. Schaalvergroting en specialisatie in de landbouwsector zullen die leefbaarheid naar verwachting niet negatief beïnvloeden. Wel is het zaak om een goede bestemming te geven aan vrijkomende boerderijen en om, met name via verbrede landbouw, de verbinding tussen de dorpen en de landbouw op peil te houden c.q. te versterken.

\section{Vrijkomende agrarische bedrijfsgebouwen}

In de toekomst zullen jaarlijks naar verwachting enige tientallen agrarische bedrijfsgebouwen in Flevoland aan de landbouw onttrokken worden als gevolg van de doorgaande schaalvergroting in de 
landbouw. Tot op heden is er geen sprake van leegstand, doordat ex- of niet-agrariërs, soms ook ondernemers uit een andere branche, deze woningen en bedrijfsgebouwen overnemen en gebruiken voor alternatieve doeleinden.

Om de leefbaarheid van het platteland goed te houden is het belangrijk ook in de toekomst leegstand te vermijden. Hiervoor zullen waarschijnlijk extra maatregelen nodig zijn, zoals verruiming van de bestemmingsplannen (bijvoorbeeld toelaten van detailhandel) of een 'rood voor rood'-regeling, waarbij agrarische bedrijfsgebouwen mogen worden afgebroken ten behoeve van woningbouw.

Bij de overblijvende agrarische bedrijven is aandacht nodig voor het verbeteren van de verkavelingsstructuur door grond 'op afstand' zo dicht mogelijk bij de bedrijfsgebouwen te situeren. Vrijwillige kavelruil en dergelijke zijn hiervoor nodig. Juist bij trends van schaalvergroting en specialisatie is veel aandacht nodig voor de bedrijfsvoering en moeten rijtijden zoveel mogelijk beperkt worden. Dit is ook van belang in verband met de verkeersveiligheid.

\section{Ontsluiting landelijk gebied}

Naar verwachting zullen er zeker maatregelen nodig zijn om de verkeersdoorstroming en -veiligheid in het landelijk gebied van de provincie te verbeteren. Ook de aanleg van snel internet op het platteland is noodzakelijk voor optimalisering van een duurzame bedrijfsvoering in de land- en tuinbouwsectoren van de provincie.

\section{Bodemdaling}

De landbouw in de provincie zal moeten leren omgaan met nattere bodemomstandigheden door het grondgebruik in sommige gebieden aan te passen. Akkerbouwgrond kan dan bijvoorbeeld omgevormd worden tot grasland, dat veel beter tegen nattere omstandigheden bestand is. Door agrarische en aanverwante functies zoals natuurbeheer en andere vormen van verbrede landbouw te combineren is er in dergelijke gebieden zeker nog wel een boterham te verdienen.

\section{Kansen in de keten}

Uit logistieke overwegingen en vanuit werkgelegenheidsoogmerk zou extra be- en verwerking van agrarische producten in de provincie zelf welkom zijn. Dat kan bijvoorbeeld doordat ondernemers zelf landbouwproducten (gaan) be- en verwerken. De omvang van de agrarische bouwpercelen mag dan geen knelpunt vormen als extra activiteiten een grotere oppervlakte aan bedrijfsgebouwen vergen. Daarnaast kan hierbij ook gedacht worden aan het benutten van vrijkomende erven van anderen.

\section{Pionieren 2.0}

Voor versterking van het innovatieve vermogen van agrarisch ondernemers, van de duurzaamheid van de landbouw en van de multifunctionaliteit van het landelijk gebied in Flevoland is

experimenteerruimte en versterking van ondernemerschap nodig. De kennisinstellingen in de provincie kunnen hierbij een rol spelen.

\section{Uitbreidingsmogelijkheden intensieve veehouderij}

De intensieve veebedrijven in Flevoland zijn weinig in getal. Hun uitbreidingsplannen zullen tot weinig negatieve gevolgen leiden. De melkveebedrijven zijn groter in aantal. Zij hebben een aanzienlijke groeidrang maar worden daarin beperkt door de melkveewet en de komende fosfaatrechten. De resterende grondbehoefte kan wellicht in samenwerking met akkerbouwers worden ingevuld.

\section{Overige punten uit de AVP}

De dominante ontwikkelingen in de landbouw in Flevoland zijn schaalvergroting en specialisatie. Die trends staan voor een deel op gespannen voet met wensen voor natuurontwikkeling, recreatie en toerisme en verbetering van de bodemkwaliteit. Voor een deel van deze wensen kan ruimte gemaakt worden door aansluiting te zoeken bij verbrede landbouwbedrijven in de provincie. Daarnaast zou verbetering van het bodembeheer en (verbreed) ondernemerschap breed door de landbouwsector opgepakt moeten worden, in samenwerking met de kennisinstellingen in de provincie. Beter bodembeheer kan op korte termijn leiden tot minder inkomen, maar is wel noodzakelijk om de landbouw in Flevoland op termijn gezond en rendabel te houden. 


\section{Toekomstperspectief voor de periode tot 2025}

\subsection{Toekomstverwachtingen per sector}

In de akkerbouw zullen de arealen van de bestaande gewassen de komende 10 jaar naar verwachting niet sterk veranderen. $\mathrm{Er}$ is wel een groei te verwachten van het pootgoedareaal ten koste van de teelt van consumptieaardappelen. Uien zullen in areaal doorgroeien en vollegrondsconserventeelten zullen stabiliseren. De oppervlakte granen zal kleiner worden ten gunste van grasland en snijmais. De opbrengstprijs van suikerbieten zal naar beneden gaan. Naar verwachting blijft het saldo echter voldoende op peil, zodat eerder een uitbreiding dan krimp van het areaal verwacht mag worden. Kansen liggen er voor de akkerbouw in het leveren van grondstoffen voor de biobased economy. Bij de teelt van akkerbouwgewassen gaat het dan vooral om inhoudsstoffen, in de verwerkende industrie om rest- en afvalstromen.

Voor de bloembollenteelt in Flevoland is het gunstig dat er de komende jaren een voortgaand herstel van de wereldeconomie verwacht wordt. Dat zal positief uitpakken voor de vraag naar bloembollen. Zowel de lokale telers als de verhuurders van bollengrond in Flevoland zullen daarvan profiteren. Het areaal bollengrond in Flevoland zal naar verwachting de komende jaren dan ook verder groeien.

Het glastuinbouwgebied in de Noordoostpolder zal zich naar verwachting verder ontwikkelen. Vooral voor nieuwkomers die een locatie zoeken van bovengemiddelde omvang, zijn hier vestigingsmogelijkheden.

Het aantal melkveehouders in Flevoland zal de komende jaren, conform het landelijk beeld, afnemen. Het aantal melkkoeien neemt tot 2025 naar verwachting toe met hooguit 10\%. Dat is minder dan eerder geschetste landelijke verwachtingen $(+20 \%)$, wat komt doordat de komende fosfaatquotering een forse rem op de groei zal zetten. De melkproductie per koe zal blijven stijgen. De melkproductie per ha zal naar verwachting toenemen. Grondruil met akkerbouwers zal verder toenemen.

De varkenshouderij in Nederland (en ook in Flevoland) heeft het moeilijk; ook op termijn is het perspectief onzeker. Instroom van varkensbedrijven zal naar verwachting niet of nauwelijks plaatsvinden. Een vermindering van het aantal varkensbedrijven in de provincie ligt meer voor de hand. Instroom van pluimveehouders in Flevoland zal naar verwachting nauwelijks plaatsvinden.

Momenteel is ruim $8 \%$ van het landbouwareaal in Flevoland in gebruik van biologische telers. Verwacht wordt dat de biologische landbouw zich richting 2025 verder uit zal breiden tot circa $15 \%$ van het areaal.

\subsection{Verwachte arealen, veestapel en aantallen bedrijven in 2025}

\section{Gewasarealen}

Op basis van de overwegingen en conclusies van de voorgaande hoofdstukken is een inschatting gemaakt van de te verwachten consequenties daarvan voor de totale gewasarealen in Flevoland in 2025. In Tabel 6.1 zijn deze arealen weergegeven, waarbij er rekening mee is gehouden dat de komende tien jaar 1.000 ha aan het landbouwareaal in Flevoland zal worden onttrokken voor de ontwikkeling van andere (niet-agrarische) sectoren. Ter vergelijking zijn ook de arealen anno 2014 in de tabel opgenomen. 
De belangrijkste uitkomst van de inschatting, zoals weergegeven in de tabel, is dat voedergewassen, opengrondstuinbouwgewassen en pootaardappelen de komende jaren in belang toe zullen nemen, ten koste van vooral de laag salderende gewassen (granen en overige akkerbouwgewassen) en de consumptieaardappelen.

\section{Tabel 6.1}

Geregistreerde en te verwachten gewasarealen in Flevoland in 2014 en 2025 (in ha)

\begin{tabular}{|c|c|c|}
\hline Gewas(groep) & \multicolumn{2}{|c|}{ Areaal in jaar: } \\
\hline Granen & 16.200 & 13.000 \\
\hline Consumptieaardappelen & 10.600 & 9.000 \\
\hline Suikerbieten & 9.500 & 10.000 \\
\hline Uien & 10.000 & 10.500 \\
\hline Akkerbouwmatige groenten & 7.000 & 7.000 \\
\hline Overige akkerbouwgewassen & 1.200 & 900 \\
\hline Bloembollen & 3.200 & 3.500 \\
\hline Totaal & $\mathbf{8 8 . 8 0 0}$ & 87.750 \\
\hline Waarvan biologisch & 8.100 & 13.000 \\
\hline
\end{tabular}

a) Bron: Landbouwtelling 2014; b) Bron: Inschattingen LEI op basis van analyse in hoofdstuk 4 voor de arealen op alle bedrijfstypen, dus niet alleen op de akkerbouwbedrijven (dit is een verschil met Figuur 2.2).

\section{Veestapel}

Evenals voor de gewasarealen is ook voor de veestapel een inschatting gemaakt van de te verwachten omvang in de komende jaren (Tabel 6.2). Er mag op basis van de toekomstige trends (hoofdstuk 4) worden verwacht dat de aantallen vleeskuikens, melkkoeien en melkgeiten toenemen. De varkens- en schapenstapel zullen gaan krimpen. Voor de leghennenhouderij wordt een stabilisatie verwacht.

\section{Tabel 6.2}

Huidige en te verwachten veestapel in Flevoland (in aantallen dieren)

\begin{tabular}{lrr} 
Diersoort/-categorie & Aantal in jaar: & \\
\cline { 2 - 3 } Leghennen & 2014 a) & 2025 b) \\
\hline Vleeskuikens & 1.340 .000 & 1.340 .000 \\
\hline Vleesvarkens & 650.000 & 710.000 \\
\hline Fokvarkens & 35.000 & 28.000 \\
\hline Melkkoeien & 6.000 & 5.000 \\
\hline Jongvee $<1$ jaar & 33.000 & 36.000 \\
\hline Jongvee $>1$ jaar & 13.000 & 14.000 \\
\hline Schapen & 12.000 & 13.000 \\
\hline
\end{tabular}

a) Bron: Landbouwtelling 2014; b) Bron: Inschattingen LEI op basis van analyse in hoofdstuk 4 voor de dieraantallen op alle bedrijfstypen, dus niet alleen op de gespecialiseerde veebedrijven (dit is een verschil met Tabel 2.7).

\section{Aantal bedrijven}

Aan de hand van het aantal te verwachten dieren en de ontwikkelingen in schaalgrootte is het aantal land- en tuinbouwbedrijven in de periode 2014-2025 geschat (Tabel 6.3). Daaruit blijkt een afname van het aantal bedrijven met ongeveer $2 \%$ per jaar. Dat percentage ligt op eenzelfde niveau als in de afgelopen 10 jaar (2005-2014). 
Op basis van de schattingen van aantallen bedrijven, arealen c.q. dieren in de verschillende sectoren is de gemiddelde bedrijfsomvang voor 2025 geschat (Tabel 6.4). Gemiddeld over de sectoren heen neemt de bedrijfsomvang in ha of dieraantallen in de komende tien jaar naar verwachting met $20 \%$ toe. Opvallende groeiers zijn de glastuinbouw- (33\%), melkvee- (29\%) en de biologische bedrijven (25\%). De intensieve veebedrijven groeien duidelijk minder sterk in bedrijfsomvang (10 à $15 \%$ ).

\section{Tabel 6.3}

Huidige en te verwachten aantallen gespecialiseerde bedrijven in Flevoland

\begin{tabular}{lrr} 
Bedrijfistype & Aantal bedrijven in jaar: \\
Alle bedrijfstypen & 2014 & $\mathbf{2 0 2 5}$ \\
\hline Waarvan akkerbouwbedrijven & $\mathbf{1 . 7 7 0}$ & $\mathbf{1 . 5 0 0}$ \\
\hline Waarvan melkveebedrijven & 800 \\
\hline Waarvan bedrijven met fokvarkens & 216 & 200 \\
\hline Waarvan bedrijven met vleesvarkens & 70 & 22 \\
\hline Waarvan bedrijven met leghennen & 33 & 30 \\
\hline Waarvan bedrijven met vleeskuikens & 18 \\
\hline Waarvan glastuinbouwbedrijven & 18 \\
\hline Waarvan biologische bedrijven & 70 \\
\hline
\end{tabular}

a) In deze tabel staan alleen de gespecialiseerde bedrijfstypen. Allerlei vormen van gemengde bedrijfstypen alsmede graasdierbedrijven ontbreken, zodat de optelling over de weergegeven bedrijfstypen lagere totalen geeft dan de aantallen onder 'alle bedrijfstypen'.

b) Bron: Landbouwtelling 2014

c) Bron: Inschattingen LEI op basis van analyse in hoofdstuk 4 en de Tabellen 6.1 en 6.2 .

\section{Tabel 6.4}

Ontwikkeling schaalgrootte van de bedrijven

\begin{tabular}{|c|c|c|c|}
\hline Bedrijfstype & \multicolumn{3}{|c|}{ Omvang per bedrijf in: } \\
\hline Akkerbouwbedrijven & ha & 55 & 65 \\
\hline Bedrijven met fokzeugen & aantal fokzeugen & 630 & 700 \\
\hline Bedrijven met vleesvarkens & aantal vleesvarkens & 1.060 & 1.200 \\
\hline Bedrijven met vleeskuikens & aantal vleeskuikens & 35.000 & 40.000 \\
\hline Glastuinbouwbedrijven & ha & 3,0 & 4,0 \\
\hline Alle bedrijfstypen & ha & 50 & 58 \\
\hline Biologische landbouw & ha & 52 & 65 \\
\hline
\end{tabular}

a) Bron: Landbouwtelling 2014.

b) Bron: Inschattingen LEI op basis van analyse in hoofdstuk 4 en de Tabellen 6.1 en 6.2. 


\section{$7 \quad$ Conclusies en aanbevelingen}

\subsection{Conclusies}

De agrarische sector in Flevoland is relatief sterk en financieel gezond. De kg-opbrengsten per ha en per koe zijn er hoog en de bedrijven zijn gemiddeld groter dan in de rest van Nederland. Tegenover hoge geld-opbrengsten per ha staan ook hoge kosten per ha door onder andere hoge inputniveaus en hoge kosten voor grond, gebouwen en machines. Deze hoge-kostenstructuur maakt de agrarische sector in Flevoland kwetsbaar. Als de benodigde hoge opbrengsten niet worden gehaald door lagere kg-opbrengsten bij gemiddelde prijzen of, erger nog, door (zeer) lage prijzen van met name aardappelen, uien, suikerbieten, granen en melk (bijvoorbeeld in een situatie van een overvloedige productie in heel Noordwest-Europa), kunnen bedrijven in financiële problemen komen. Deze situatie vraagt aandacht voor risicomanagement.

Mede door de hoge kostenstructuur van de Flevolandse landbouw zullen de huidige trends van schaalvergroting en specialisatie en/of intensivering zich door zetten. Schaalvergroting is mogelijk doordat een deel van de agrarische ondernemers geen opvolger heeft, zodat bestaande bedrijven kunnen uitbreiden door aankoop of pacht van vrijkomende bedrijven of kavels. De gerealiseerde bedrijfsuitbreiding vindt evenwel niet altijd dicht bij huis plaats, waardoor de gemiddelde rij-afstanden en kostprijzen toenemen. In combinatie met toename van losse huur van grond voor specialistische teelten als aardappelen is de afgelopen jaren de verkavelingsstructuur in Flevoland verslechterd; er is sprake van versnippering. Voor verbetering van de slagkracht en de duurzaamheid van de agrarische bedrijven is aandacht voor vrijwillige vormen van kavelruil noodzakelijk. Beperking van transportafstanden is ook van belang voor de belasting van het wegennet en de verkeersveiligheid.

De bodem in Flevoland wordt intensief gebruikt en bewerkt. Gezien de hoge-kostenstructuur in de provincie is dat begrijpelijk. Alleen komen hier de grenzen van het systeem in zicht en is meer aandacht voor extensivering van bouwplannen noodzakelijk. Dit zal op korte termijn het inkomen van agrariërs onder druk zetten, maar op langere termijn de continuïteitskansen van teelten en bedrijven versterken. De integrale duurzaamheid van Flevoland, waarin voor zowel people, planet als profit voldoende aandacht is, verdient veel aandacht. Flevoland kan onder andere dienen als proefgebied voor moderne vormen van precisielandbouw, waarbij de 'drie P's' als geheel geoptimaliseerd worden. Voor de geautomatiseerde administratie op de moderne landbouwbedrijven alsmede voor optimale benutting van precisielandbouwtechnieken is de aanleg van snel internet op het platteland overigens een absolute voorwaarde.

De leefbaarheid van het Flevolandse platteland is goed. Door schaalvergroting en verdergaande mechanisatie en automatisering van de landbouw wordt de verbinding met de burgerbevolking in de dorpen zwakker. Dit is een punt van aandacht, waarbij met name vormen van verbrede landbouw de verbinding kunnen versterken. Dat geldt ook voor een tendens om steeds meer producten op het boerenbedrijf te be- en verwerken. Dat kan in de toekomst vragen om grotere bouwblokken. Voor de regionale economie en de bedrijfseconomische prestaties van de landbouwbedrijven zijn verbrede activiteiten en be-/verwerking van producten van groot belang, temeer daar er in Flevoland zelf weinig verwerkende industrie aanwezig is.

Door de schaalvergroting komen er jaarlijks enige tientallen bedrijfswoningen vrij, die niet meer door agrariërs bewoond worden. Tot op heden vormt dit geen probleem in de zin van leegstand en verpaupering. Voor de toekomst is het verstandig dergelijke problemen te vermijden door maatregelen te nemen, bijvoorbeeld door nieuwe functies toe te laten in de overtollige gebouwen. 
Samengevat:

- Flevoland blijft een belangrijke akkerbouwprovincie.

- De Flevolandse landbouw is zeer kapitaalintensief, dit bepaalt in hoge mate de ondernemersstrategieën.

- De akkerbouw gaat verder intensiveren, ondanks de grotere noodzaak tot duurzamer bodembeheer en vergroening.

- De biologische landbouw groeit door.

- Ketenverkorting en verbreding zal door meer bedrijven worden benut om een inkomen te genereren, soms in combinatie met vergroening en verduurzaming.

\subsection{Aanbevelingen}

\section{Blijf ruimte bieden aan bedrijfsontwikkeling}

Bedrijfsontwikkeling (schaalvergroting, specialisatie, intensivering, opbrengstverhoging, bedrijfsopvolging, be- en verwerking van producten, verbreding en dergelijke) is en blijft de belangrijkste trend in de Flevolandse land- en tuinbouw. Het is van belang dat de provincie deze trend zoveel mogelijk blijft ondersteunen en faciliteren in haar ruimtelijk- en economische beleid en dat zij ook uitspreekt dat zij de sector blijvend van belang acht voor een duurzame toekomst van de regio. Wij zien verschillende mogelijkheden en kansen om daar invulling aan te geven. Die worden in de onderstaande aanbevelingen verder uitgewerkt.

\section{Benut de kansen voor de biobased economy in Flevoland}

In Flevoland blijft schaalvergroting en intensivering ook de komende jaren de belangrijkste ontwikkelingsrichting in de land- en tuinbouw. Gezien de dominante aanwezigheid van het akkerbouwcluster in de regio worden daarbij ook kansen gezien voor de verdere ontwikkeling en stimulering van de biobased economy. De ontwikkelingen op dit gebied verlopen momenteel in een flink tempo en de verwachting is dat de markt voor biobased produkten de komende jaren fors aan zal trekken. Kansen liggen er voor de provincie Flevoland in de hogere segmenten van de biobased waardeketen, dat wil zeggen de ontwikkeling van vezels, materialen en inhoudsstoffen, bijvoorbeeld door middel van (kleinschalige) bioraffinage. Die kansen kunnen in samenwerking met andere overheden en het bedrijfsleven de komende jaren verzilverd worden.

\section{Stimuleer de be- en verwerking van landbouwproducten op het eigen bedrijf}

Voor de Flevolandse agrarische ondernemers ligt er zeker een kans om, al dan niet in gezamenlijkheid, te investeren in eigen be- en verwerking van producten. Daarmee kunnen zij hun positie in de keten versterken maar ook meerwaarde geven aan hun producten. Het zou goed zijn als de provincie die ontwikkeling stimuleert en faciliteert, bijvoorbeeld in het RO-beleid (grotere bouwblokken) maar ook in overleg met de gemeenten over het vergunningenbeleid. Ook zou zij onderzoek kunnen entameren naar de logistieke optimalisatie van deze ontwikkeling, met in een latere fase wellicht ondersteuning via het bieden van investeringsruimte.

\section{Stimuleer en promoot de precisielandbouw}

Voor wat betreft de sector zelf zal de precisielandbouw met name in de plantaardige sectoren de komende jaren een grote vlucht gaan nemen. Daarmee kan zowel het niveau van productie en kwaliteit van de teelt verbeterd worden als het gebruik van meststoffen en gewasbeschermingsmiddelen verder beperkt worden. Ook maakt deze ontwikkeling schaalvergroting gemakkelijker, omdat de arbeids-productiviteit ermee vergroot wordt. Het is goed dat de provincie die ontwikkeling faciliteert, door bijvoorbeeld onderzoek op dit vlak te stimuleren. Precisielandbouw kan een belangrijke rol spelen bij het oplossen van milieuvraagstukken in de Flevolandse land- en tuinbouw. De provincie zou zelfs in kunnen zetten op het promoten van Flevoland als het wereldwijde centrum voor precisielandbouw. Wellicht kan hierbij aansluiting gezocht worden bij de ontwikkeling en promotie van de Floriade 2022. Daar waar precisielandbouw en schaalvergroting aandacht vragen vanuit het omgevingsbeleid zou de provincie zich faciliterend op kunnen stellen, bijvoorbeeld door te investeren in een betere ontsluiting van het platteland, zowel logistiek als digitaal. 


\section{Draag bij aan het optimaliseren van de verkavelingsstructuur}

Geconstateerd moet worden dat schaalvergroting voor de Flevolandse boeren niet altijd even gemakkelijk is. De grondprijzen zijn hoog en er komt in beperkte mate grond op de markt. $\mathrm{Er}$ is relatief veel concurrentie op de grondmarkt, zowel tussen ondernemers uit de provincie als van ondernemers die elders uitgekocht zijn of willen beleggen in landbouwgrond. Ook zijn projectontwikkelaars in delen van de provincie actief om grond aan de agrarische sector te onttrekken voor andere bestemmingen en vragen andere functies, zoals bijvoorbeeld natuurontwikkeling, ook ruimte. Aanbevolen wordt dat de provincie laat onderzoeken hoe de grond- en pachtmarkt in haar regio verbeterd kan worden. Zij kan hiertoe ook projecten entameren die de verkavelingsstructuur optimaliseren. Denk hierbij bijvoorbeeld aan het inzetten van het Verkavelen voor Groei instrumentarium van LTO Nederland en het Kadaster (vrijwillige kavelruil). Ruilen van pachtgrond zou in dat kader ook een mogelijke optie zijn.

\section{Ondersteun de bedrijfsopvolging}

De provincie dient aandacht te besteden aan de opvolgingssituatie op de Flevolandse land- en tuinbouwbedrijven. Er staan relatief veel bedrijfsopvolgers klaar, maar de financiering van de bedrijven wordt steeds moeilijker door de steeds hogere kapitaallasten. Daardoor komt er meer vreemd kapitaal de sector in, maar daar zijn de bedrijfsopvolgers niet altijd bij gebaat. Aanbevolen wordt dat de provincie Flevoland, in gezamenlijkheid met de andere provincies in ons land, bij het Rijk pleit voor fiscale maatregelen en verhoging van de steun uit Brussel aan jonge boeren. Ook kan de provincie nieuwe bedrijfsvormen ondersteunen, zoals bijvoorbeeld een BV of een stichting.

\section{Faciliteer de groei van de biologische landbouw}

Flevoland is een voorloper op het gebied van de biologische landbouw. Deze sector neemt in Flevoland een relatief sterke positie in en zou nog meer gebruik kunnen maken van haar voorsprong op andere regio's. De provincie kan faciliteren bij het opzetten van (nieuwe) regionale clusters van biologische landbouw, waar primaire productie, verwerking en afzet geconcentreerd worden, met name in korte ketens. Ook kan zij daartoe het (praktijk-)onderzoek op het gebied van de biologische landbouw steviger ondersteunen.

\section{Benut de kansen voor verbreding}

Hoewel verbreding een niet onbelangrijke rol speelt in de Flevolandse land- en tuinbouw, zijn de mogelijkheden om hier als provincie een rol in te spelen beperkt. Men kan hooguit de gemeenten kaders meegeven waarmee in bestemmingsplannen ruimte voor verbrede landbouwactiviteiten (inclusief verwerking van landbouwproducten op het bedrijf) en kleinschalige niet-agrarische bedrijvigheid in (voormalige) agrarische bedrijfsgebouwen wordt gegeven. Kansen liggen er op dit vlak zeker voor het nieuwe collectief van agrarische ondernemers dat in Flevoland gevormd wordt voor de toekomstige opzet en de organisatie van het agrarisch natuurbeheer per 1 januari 2016. Wellicht kan dit collectief op termijn uitgroeien tot een speler van formaat, die ook andere groene en blauwe diensten voor provincie, waterschap en gemeenten in Flevoland verzorgt.

\section{Faciliteer de transformatie van vrijkomende bedrijfsgebouwen}

Ook in de toekomst zal jaarlijks een aantal agrarische bedrijfsgebouwen in Flevoland aan de sector onttrokken worden door de voortgaande schaalvergroting in de landbouw. Om leegstand en verpaupering van dergelijke gebouwen te voorkomen, zullen extra maatregelen nodig zijn, zoals verruiming van de bestemmingsplannen (bijvoorbeeld toelaten van detailhandel) of een "rood voor rood" regeling, waarbij agrarische bedrijfsgebouwen vervangen mogen worden door woningbouw. Aanbevolen wordt dat de provincie hiervoor een beleidskader ontwerpt.

\section{Naar een onderzoeks- en stimuleringsprogramma voor bodemdaling en bodemvruchtbaarheid} Algemeen wordt erkend dat een goede bodemkwaliteit noodzakelijk is voor de doorgaande productieverhoging in de landbouw. Kennis is daarbij het belangrijkste knelpunt. Aanbevolen wordt de provincie hiervoor een onderzoeks- en stimuleringsprogramma entameert. Ook zal de landbouw in Flevoland, uitgaande van het toenemende probleem van de bodemdaling, moeten leren omgaan met nattere bodemomstandigheden door het grondgebruik in sommige gebieden aan te passen. Akkerbouwgrond kan dan bijvoorbeeld omgevormd worden tot grasland, dat veel beter tegen nattere omstandigheden bestand is. De provincie kan, samen met gemeenten en waterschap, dit aanpassingsproces faciliteren 
door onderzoek te laten doen naar innovatieve bedrijfssystemen en betrokken ondernemers te ondersteunen bij de omschakeling naar die systemen.

\section{Promoot Flevoland als exporteur van kennis}

De vraag kan gesteld worden of de provinciale ondernemers voldoende gericht zijn op het uitdragen en verwaarden van hun kennis in de rest van de wereld. Met name in de pootgoed- en de uiensector is veel kennis opgebouwd op het gebied van de teelt, bewaring en afzet, waar boeren in het buitenland heel goed van kunnen leren. Hoewel dit in eerste instantie de verantwoordelijkheid is van de sector zelf, kan de provincie deze export van kennis heel goed stimuleren en entameren. Dit kan gecombineerd worden met de centrale rol die Flevoland in Nederland en in de wereld zou kunnen spelen op het terrein van precisielandbouw en bodemvruchtbaarheid (zie aanbeveling 4).

\section{Creëer een Platform Duurzame Landbouw Flevoland}

Daarnaast wordt geadviseerd dat de provincie een Platform Duurzame Landbouw opzet, waarin koplopers van binnen en buiten de sector samenwerken met ketenpartijen om oplossingen te vinden voor vraag-stukken in de teelt, de verwerking en de afzet (inclusief de logistiek), maar ook nadenken over nieuwe producten en nieuwe samenwerkingsverbanden in de keten. Vanuit een dergelijk platform kan dan ook (half-) jaarlijks een netwerkbijeenkomst georganiseerd worden om de opgedane kennis en gedachten te delen met een groter publiek en partijen gericht bij de innovaties te betrekken.

\section{Zet een Innovatieprogramma Agrosector Flevoland op}

Daarmee verbonden wordt aanbevolen dat de provincie, in samenwerking met kennispartijen uit de regio, een Innovatieprogramma Agrosector Flevoland ontwikkelt, waarmee de kennis- en co-creatieopgaven gedefinieerd worden die nodig zijn om de innovaties uit het Platform Duurzame Landbouw verder te brengen. Die opgaven kunnen vervolgens gericht door de provincie uitgezet worden. Daar is wel een apart budget voor nodig.

\section{Stel een Ambitieprogramma 2025 voor de Flevolandse land-en tuinbouw op} Tenslotte bevelen wij aan dat de provincie, mede op basis van het voorgaande, samen met haar stakeholders gaat werken aan een Ambitieprogramma 2025 voor de Flevolandse land- en tuinbouw, waarin de route richting 2025 geschetst wordt, inclusief concrete acties van partijen om daar te komen.

Samengevat:

- Blijf ruimte bieden aan bedrijfsontwikkeling (daaronder valt ook ruimte bieden aan be- en verwerking op het eigenbedrijf, ondersteunen van innovaties).

- Biedt ook ruimte aan nieuwe ontwikkelingsrichtingen (waaronder de biobased economy).

- Blijf investeren in internationalisering (Flevoland heeft een goede naam, bouw die verder uit).

- Investeer in technologische ontwikkeling; ontwikkel een Innovatieprogramma.

- Investeer in de verdere verduurzaming van de Flevolandse landbouw, onder andere door de oprichting van een Platform Duurzame Landbouw. 


\section{Literatuur}

Baltussen, W.H.M., M.A. Dolman, R. Hoste, S.R.M. Janssens, J.W. Reijs en A.B. Smit, 2015. Grondstofefficiëntie in de zuivel-, varkensvlees-, aardappel- en suikerketen. Wageningen, LEI Wageningen UR (University \& Research centre), LEI Nota 2015-038 (in press).

Baltussen, W.H.M., M.A. Dolman, R. Hoste, S.R.M. Janssens en A.B. Smit, 2016. Gebruik van reststromen in de zuivel-, varkensvlees-, aardappel- en suikerketen. Wageningen, LEI Wageningen UR (University \& Research centre), LEI Nota (in wording).

Berkhout, P., H. Silvis en I. Terluin (red.), 2014. Landbouw-Economisch Bericht 2014, Den Haag, LEI-rapport 2014-013 (met medewerking van onder andere A.B. Smit).

Berkhout, P., M. van Asseldonk, J. Benninga, L. Gé, R. Hoste en B. Smit, 2015a. De kracht van het agrocluster. Het belang van de primaire landbouw voor het totale agrocomplex. Wageningen, LEI Wageningen UR (University \& Research centre), LEI Report 2015-032.

Berkhout, P., H. Silvis, I.J. Terluin, A. Pronk, D. Oudendag, M.J. Voskuilen en H. van der Meulen, 2015b, Het Landbouw-Economisch Bericht 2015, Den Haag, LEI Wageningen UR, www.landbouweconomischbericht.nl

Brouwer, F., B. Smit en R. Verburg, 2015. Economische prikkels voor vergroening in de landbouw, WOT Natuur \& Milieu, Wageningen UR, WOt-interne notitie (in press).

Bruns, C. en $\mathrm{H}$. van den Brink, 2014. Teelt uien in opmars, Akkerbouwers vertrouwen op verdere exportgroei. ING Economisch Bureau, 5 p.

Dekking, A.J.G., 2015. Stadslandbouw in Almere. De stand van zaken op 1 januari 2015. PPO-629, Wageningen UR, PPO AGV. 61 pp.

Harmsen, P., S. Lips, H. Bos (Wageningen UR-Food and Biobased Research), B. Smit, S. van Berkum, J. Helming en R. Jongeneel (LEI Wageningen UR), 2014. Suiker als grondstof voor de Nederlandse chemische industrie; gewassen, proces, beleid, Wageningen, FBR-rapport Nummer 1494, www. wageningenur. nl/nl/Publicatie-details. htm?publicationId=publication-way-343536323436

Janssens, S.R.M. en A.B. Smit, 2000. Heeft precisielandbouw (de) toekomst? Den Haag, LEI, Rapport 1.00 .02

Kortstee, H., N. Hamers-van den Berkmortel, K. de Grip, H. Hermans, B. Smit, R. Stokkers en M. de Vlas, 2011, Een leven lang leren. Voortdurende ontwikkeling van ondernemerscompetenties in kenniscoalities, Den Haag, LEI-rapport 2011-069.

Lauwere, C.C. de, Buck, A.J. de, Smit, A.B., Buurma, J.S., Drost, H., Prins, H. en Theuws, L.W., 2003. Omschakelen naar geïntegreerde of biologische teelt: motieven, voorwaarden, risico's, mogelijke oplossingsrichtingen en de rol van de ondernemer. IMAG-rapport 2003-02, Wageningen UR, Wageningen.

Meulen, H. van der et al., 2014. Kijk op Multifunctionele landbouw, Omzet- en impact 2007-2013, brochure, LEI Wageningen UR.

Gemeente Lelystad, Overdrachtsdocument Stadslandbouw en Buurttuinen, Lelystad, 2014.

Silvis, H., K. Smekens, D. Verhoog en B. (ECN), met medewerking van B. Smit, G. Doornewaard, N. van der Velden, A.Wisman, J. van den Briel en J. Oldenburger, 2015. Opties voor energieneutrale agrosectoren in 2025 (in druk).

Smit, A.B., J.J. Stoorvogel en G.A.A. Wossink (2000). A methodology to support the decision to invest in spatially variable nitrogen fertilisation. Netherlands Journal of Agricultural Science, 48, 273-290

Smit, A.B., H.J.M. Kortstee, N.J. Jukema (PPO-agv), J. Meijaard (EIM), S. Oudmaijer (EIM), N. Idema, F. Pleijster (EIM), R.M. Braaksma (EIM) en J. van Staalduinen (Van Staalduinen Communicatie), 2009. Samen werken aan samenwerking. LEI Wageningen UR, Den Haag, Rapport 2009-082, 233 pp.; http://edepot.wur.nl/50970

Smit, A.B., C.J.A.M. de Bont, J.F.M. Helming, M.G.A. van Leeuwen, R.W. van der Meer, P. Berkhout, M. van Dijk, S.R.M. Janssens en J.H. Jager, 2011. Wel of geen suikerquotering? Economische gevolgen voor sector, keten, internationale marktverhoudingen en derde wereld, Den Haag, LEI-rapport 2011-056. 
Smit, A.B., H. Prins, M. Litjens, A. van den Ham, J. Bijman, B.W. Zaalmink, 2015.

Producentenorganisaties als instrument voor concurrentiekracht en innovatie; Uitbreiding van perspectief door het nieuwe GLB? Wageningen, LEI Wageningen UR (University \& Research centre), LEI Report i.w.

J.J.M. Staps, C. ter Berg, A. van Vilsteren, E.T. Lammerts van Bueren en T.H. Jetten, 2015. Van bodemdilemma's naar integrale verduurzaming - Casus: Vruchtbaar Flevoland, van bodemdegradatie en diepploegen naar integrale duurzame productie in Flevoland, www.ridlv.nl, 58 pp.

Veen, E., Proefschrift Stadslandbouw, Wageningen, 2015.

Veen, E., B. Breman en J.E. Jansma, 2012. Stadslandbouw. Een verkenning van groen en boer zijn in en om de stad. Wageningen UR, PPO AGV. 42 pp.

Jongeneel, R., M. van Leeuwen en D. Verhoog PPS Market Outlook Agro\&Food, medium term Outlook 2015-2024. Lei, Den Haag, unpublished).

Wetenschappelijke en Technologische Commissie voor de biobased economy, 2013. Strategie voor een groene samenleving; Biomaterialen, drijfveer voor de biobased economy. 


\section{Bijlage 1 Aanvullende informatie bij Figuur 2.1}

Tabel ontwikkeling arealen per bedrijfstype in Flevoland en Nederland

\begin{tabular}{lrrrrrrrrrr} 
& \multicolumn{3}{c}{ Flevo } & \multicolumn{4}{c}{} & \multicolumn{4}{c}{ index NL = 100 (per jaar) } \\
\cline { 2 - 11 } akkerbouw & 2005 & 2010 & 2014 & 2005 & 2010 & 2014 & 2005 & 2010 & 2014 \\
\hline melkvee & 49 & 54 & 55 & 36 & 38 & 39 & 137 & 140 & 142 \\
\hline overige graasdieren & 49 & 56 & 60 & 41 & 47 & 49 & 117 & 119 & 121 \\
\hline gemengd & 21 & 18 & 15 & 13 & 13 & 13 & 165 & 145 & 117 \\
\hline intensief & 45 & 59 & 66 & 33 & 38 & 41 & 137 & 155 & 163 \\
\hline glastuinbouw & 21 & 22 & 26 & 11 & 12 & 13 & 202 & 191 & 209 \\
\hline totaal & 4 & 4 & 6 & 2 & 3 & 4 & 155 & 125 & 149 \\
\hline
\end{tabular}

17 De totaalindex voor Flevoland en Nederland als geheel betreft de verhouding tussen het naar sector gewogen gemiddelde areaal per bedrijf in Flevoland en in Nederland als geheel. De weging naar sector verschilt tussen Flevoland en Nederland, waardoor deze index hoger uitkomt dan voor de afzonderlijke sectoren. Met name weegt het kleine aantal glastuinbouwbedrijven in Flevoland ten opzichte van Nederland met relatief kleine bedrijfsarealen (in ha) sterk door in deze index. 


\section{Bijlage 2 Aanvullende informatie bij Figuur 2.8}

Tabel standaardopbrengst (SO) per bedrijf NL versus Flevo

\begin{tabular}{lrrrrrrrrr} 
& \multicolumn{4}{c}{ NL } & \multicolumn{3}{c}{ Flevo } & \multicolumn{3}{c}{ index NL = 100 (per jaar) } \\
\cline { 2 - 11 } & 2005 & 2010 & 2014 & 2005 & 2010 & 2014 & 2005 & 2010 & 2014 \\
\hline akkerbouw & 87.730 & 105.680 & 122.402 & 178.994 & 221.044 & 267.531 & 204 & 209 & 219 \\
\hline melkvee & 207.846 & 258.230 & 336.130 & 295.326 & 371.091 & 489.546 & 142 & 144 & 146 \\
\hline overige graasdieren & 58.580 & 64.072 & 71.054 & 185.902 & 156.603 & 137.546 & 317 & 244 & 194 \\
\hline gemengd & 213.822 & 272.835 & 314.502 & 315.296 & 426.582 & 484.219 & 147 & 156 & 154 \\
\hline intensief & 391.050 & 563.841 & 802.122 & 497.973 & 725.267 & 992.681 & 127 & 129 & 124 \\
\hline glastuinbouw & 822.864 & 1.174 .289 & 1.450 .229 & 1.227 .607 & 1.626 .987 & 1.841 .131 & 149 & 139 & 127 \\
\hline totaal & 224.025 & 271.106 & 323.935 & 290.087 & 358.622 & 417.227 & 129 & 132 & 129 \\
\hline
\end{tabular}




\section{Bijlage 3 Aanvullende informatie bij}

Figuur 2.23

\begin{tabular}{lrrr} 
& \multicolumn{2}{c}{ Aantal biologische bedrijven in jaar: } \\
\cline { 2 - 4 } Negio/sector & 2005 & 2010 & 2014 \\
\hline Zuidw. klei akkerbouw & 13 & 16 & 10 \\
\hline Flevoland akkerbouw & 41 & 30 & 29 \\
\hline Noord-NL melkvee & 61 & 61 & 69 \\
\hline Flevoland melkvee & 15 & 4 & 24 \\
\hline Totaal Flevoland & 4 & 127 & 8 \\
\hline Totaal NL & 115 & 1.305 & 156 \\
\hline
\end{tabular}




\section{Bijlage 4 Achtergrond bij de input- outputanalyse in hoofdstuk 3}

Het agrocluster wordt in de rapportages van LEI onderverdeeld in zes deelclusters, die zijn opgebouwd uit de volgende primaire en verwerkende sectoren:

1. Akkerbouwcluster: primaire akkerbouwsector en de verwerkende bedrijven van akkerbouwproducten: aardappelen, suikerbieten, granen, cacao, koffie, thee, plantaardige vetten en oliën.

2. Opengrondstuinbouwcluster: primaire sectoren (groenten in opengrond, bloembollen, fruit, boomkwekerij) en groente- en fruitverwerkende industrie.

3. Glastuinbouwcluster: primaire sectoren (glasgroenten, snijbloemen, planten, champignons) en de groente- en fruitverwerkende industrie.

4. Grondgebonden veehouderijcluster: primaire sectoren (rundveehouderij, schapen- en geitenhouderij) en de verwerkende bedrijven (zuivelindustrie, slachterijen).

5. Intensieve veehouderijcluster: primaire sectoren (vleeskalveren-, vleeskuikens, leghennen en varkenshouderij) en de slachterijen.

6. Visserijcluster: primaire visserijsector en de visverwerkende industrie.

De directe bijdrage van deze afzonderlijke clusters aan de toegevoegde waarde en de werkgelegenheid van de nationale economie en de economie van Flevoland is eenvoudig te bepalen door het optellen van de beschikbare informatie in databronnen bij CBS, Stichting LISA en het LEI. Veel lastiger is het om te bepalen hoeveel toegevoegde waarde en werkgelegenheid er indirect wordt gecreëerd bij toeleverende bedrijven. Hiervoor biedt de input-outputanalyse die op het LEI gebruikt wordt, een oplossing. Wel moet in geval van Flevoland eerst nog bepaald worden hoeveel er uit toeleverende bedrijven uit de provincie zelf komt en hoeveel van bedrijven in andere provincies. Sommige toeleverende sectoren zoals bijvoorbeeld de aardolie-industrie en de kunstmestindustrie komen in Flevoland helemaal niet voor, terwijl er door de verschillende landbouwsectoren wel een beroep op deze sectoren wordt gedaan. Om dit inzichtelijk te maken worden de resultaten uit de input-outputanalyse hiervoor gecorrigeerd.

De betekenis van het agrocluster kan op twee manieren worden weergegeven. Bij het LEI worden de zogenoemde 'ruime' definitie en de 'enge' definitie gebruikt. De enge definitie houdt voor de afbakening van de voedings- en genotmiddelenindustrie alleen rekening met de verwerking van in Flevoland geproduceerde agrarische producten terwijl de ruime definitie de gehele voedings- en genotmiddelenindustrie meeneemt ongeacht de herkomst van de agrarische grondstoffen. Dit betekent dat de in Flevoland gevestigde fruitverwerkende industrie voor $100 \%$ wordt meegenomen, ook al komt misschien een deel van het fruit uit andere provincies of zelf uit het buitenland. In deze studie gaan wij uit van de ruime definitie. 


\section{Bijlage 5 Cijfers bij Figuur 2.10}

\begin{tabular}{|c|c|c|c|c|c|}
\hline & $\begin{array}{l}\text { Noord. klei } \\
\text { akkerbouw }\end{array}$ & $\begin{array}{l}\text { Zuidw. klei } \\
\text { akkerbouw }\end{array}$ & $\begin{array}{r}\text { Flevoland } \\
\text { akkerbouw }\end{array}$ & $\begin{array}{l}\text { Noord-NL } \\
\text { melkvee }\end{array}$ & $\begin{array}{r}\text { Flevoland } \\
\text { melkvee }\end{array}$ \\
\hline$<1$ ha & 0 & 1 & 1 & 2 & 2 \\
\hline $1-5$ ha & 27 & 235 & 12 & 0 & 1 \\
\hline $5-10$ ha & 65 & 382 & 31 & 1 & 0 \\
\hline $10-20$ ha & 65 & 535 & 106 & 0 & 7 \\
\hline $20-30$ ha & 77 & 344 & 167 & 3 & 19 \\
\hline $30-50$ ha & 153 & 586 & 254 & 375 & 70 \\
\hline $50-100$ ha & 322 & 730 & 289 & 1.581 & 92 \\
\hline$>100$ ha & 217 & 272 & 103 & 375 & 25 \\
\hline
\end{tabular}


LEI Wageningen UR

Postbus 29703

2502 LS Den Haag

T 0703358330

E publicatie.lei@wur.nl

www.wageningenUR. nl/lei

\section{Rapport}

LEI 2016-008
LEI Wageningen UR is een onafhankelijk, internationaal toonaangevend, sociaaleconomisch onderzoeksinstituut. De unieke data, modellen en kennis van het LEI bieden opdrachtgevers op vernieuwende wijze inzichten en integrale adviezen bij beleid en besluitvorming, en dragen uiteindelijk bij aan een duurzamere wereld. Het LEI maakt deel uit van Wageningen UR (University \& Research centre). Daarbinnen vormt het samen met het Departement Maatschappijwetenschappen van Wageningen University en het Wageningen UR Centre for Development Innovation de Social Sciences Group.

De missie van Wageningen UR (University \& Research centre) is 'To explore the potential of nature to improve the quality of life'. Binnen Wageningen UR bundelen 9 gespecialiseerde onderzoeksinstituten van stichting DLO en Wageningen University hun krachten om bij te dragen aan de oplossing van belangrijke vragen in het domein van gezonde voeding en leefomgeving. Met ongeveer 30 vestigingen, 6.500 medewerkers en 10.000 studenten behoort Wageningen UR wereldwijd tot de aansprekende kennisinstellingen binnen haar domein. De integrale benadering van de vraagstukken en de samenwerking tussen verschillende disciplines vormen het hart van de unieke Wageningen aanpak. 

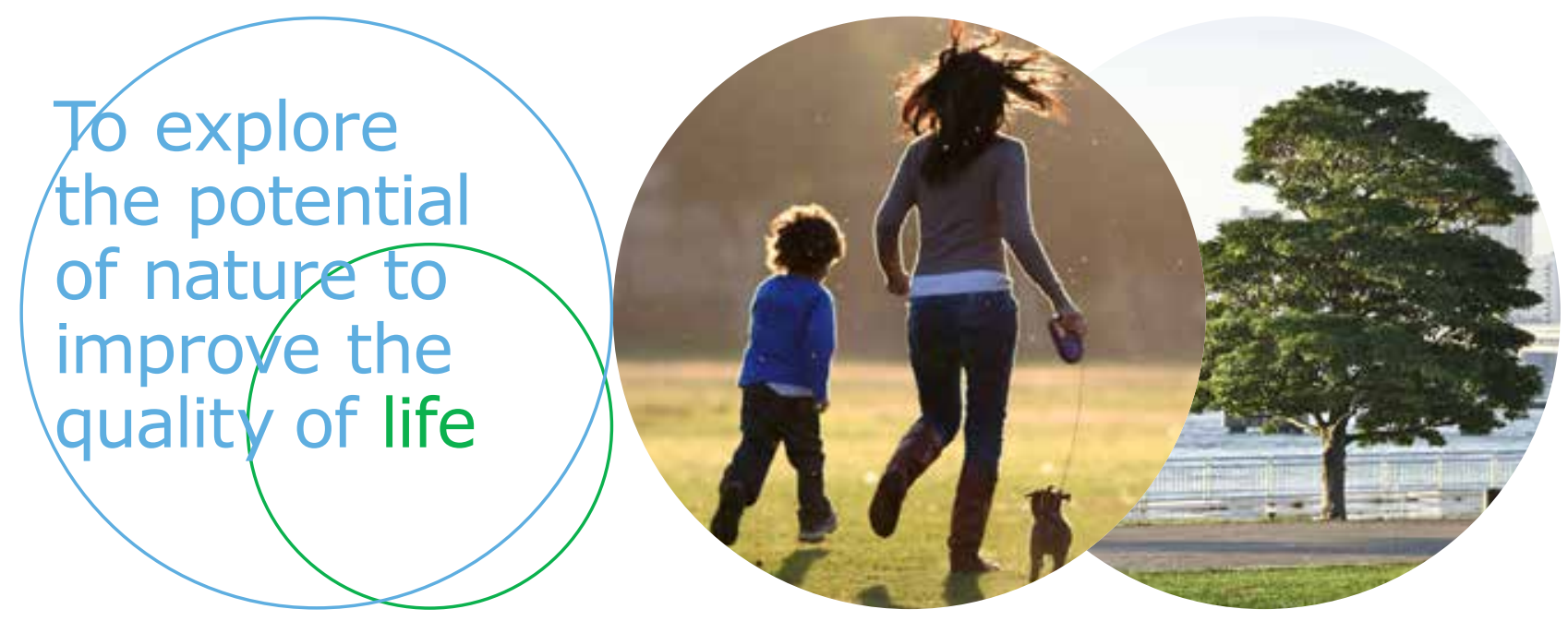

LEI Wageningen UR

Postbus 29703

2502 LS Den Haag

E publicatie.lei@wur.nl

www.wageningenUR.nl/lei

RAPPORT

LEI 2016-008

ISBN 978-94-6257-754-1
LEI Wageningen UR is een onafhankelijk, internationaal toonaangevend, sociaaleconomisch onderzoeksinstituut. De unieke data, modellen en kennis van het LEI bieden opdrachtgevers op vernieuwende wijze inzichten en integrale adviezen bij beleid en besluitvorming, en dragen uiteindelijk bij aan een duurzamere wereld. Het LEI maakt deel uit van Wageningen UR (University \& Research centre). Daarbinnen vormt het samen met het Departement Maatschappijwetenschappen van Wageningen University en het Wageningen UR Centre for Development Innovation van de Social Sciences Group.

De missie van Wageningen UR (University \& Research centre) is 'To explore the potential of nature to improve the quality of life'. Binnen Wageningen UR bundelen 9 gespecialiseerde onderzoeksinstituten van stichting DLO en Wageningen University hun krachten om bij te dragen aan de oplossing van belangrijke vragen in het domein van gezonde voeding en leefomgeving. Met ongeveer 30 vestigingen, 6.500 medewerkers en 10.000 studenten behoort Wageningen UR wereldwijd tot de aansprekende kennisinstellingen binnen haar domein. De integrale benadering van de vraagstukken en de samenwerking tussen verschillende disciplines vormen het hart van de unieke Wageningen aanpak. 